Prepared in cooperation with the Louisiana Coastal Protection and Restoration Authority

\title{
Louisiana Barrier Island Comprehensive Monitoring Program: Mapping Habitats in Beach, Dune, and Intertidal Environments Along the Louisiana Gulf of Mexico Shoreline, 2008 and 2015-16
}

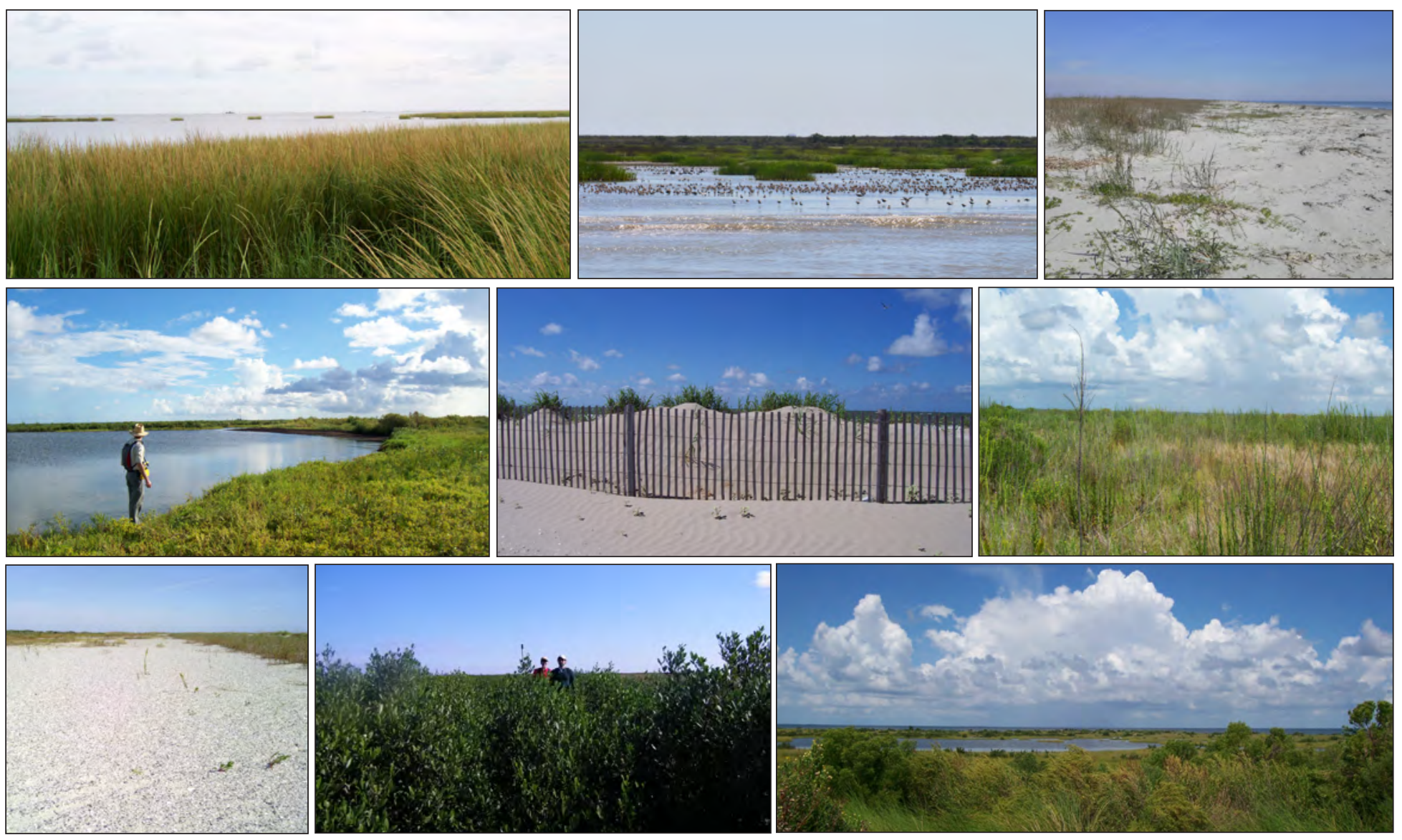

Open-File Report 2020-1030 
Cover: Examples of various habitats found on Louisiana's barrier islands, headlands, and along coastal shorelines.

Top row from left to right: estuarine emergent marsh and water; estuarine emergent marsh, intertidal, and water habitats being utilized by shorebirds; beach transitioning into unvegetated flat and meadow.

Middle row from left to right: estuarine emergent marsh, meadow, and water; beach, unvegetated dune with sand fencing, unvegetated flat, and vegetated dune; meadow and scrub/shrub.

Bottom row from left to right: unvegetated flat and meadow habitats; mangrove colonization on a recently restored backbarrier intertidal platform; meadow, scrub/shrub, estuarine emergent marsh, and mangrove habitats (listed in order from foreground to background).

Photographs by the Louisiana Coastal Protection and Restoration Authority (2007, 2008, and 2019), used with permission. 


\section{Louisiana Barrier Island Comprehensive Monitoring Program: Mapping Habitats in Beach, Dune, and Intertidal Environments Along the Louisiana Gulf of Mexico Shoreline, 2008 and 2015-16}

By Nicholas M. Enwright, William M. SooHoo, Jason L. Dugas, Craig P. Conzelmann, Claudia Laurenzano, Darin M. Lee, Kelly Mouton, and Spencer J. Stelly

Prepared in cooperation with the Louisiana Coastal Protection and Restoration Authority

Open-File Report 2020-1030 


\title{
U.S. Department of the Interior \\ DAVID BERNHARDT, Secretary
}

\author{
U.S. Geological Survey \\ James F. Reilly II, Director
}

U.S. Geological Survey, Reston, Virginia: 2020

For more information on the USGS - the Federal source for science about the Earth, its natural and living resources, natural hazards, and the environment—visit https://www.usgs.gov or call 1-888-ASK-USGS.

For an overview of USGS information products, including maps, imagery, and publications, visit https://store.usgs.gov/.

Any use of trade, firm, or product names is for descriptive purposes only and does not imply endorsement by the U.S. Government.

Although this information product, for the most part, is in the public domain, it also may contain copyrighted materials as noted in the text. Permission to reproduce copyrighted items must be secured from the copyright owner.

Suggested citation:

Enwright, N.M., SooHoo, W.M., Dugas, J.L., Conzelmann, C.P., Laurenzano, C., Lee, D.M., Mouton, K., and Stelly, S.J., 2020, Louisiana Barrier Island Comprehensive Monitoring Program-Mapping habitats in beach, dune, and intertidal environments along the Louisiana Gulf of Mexico shoreline, 2008 and 2015-16: U.S. Geological Survey Open-File Report 2020-1030, 57 p., https://doi.org/10.3133/ofr20201030.

Associated data for this publication:

Enwright, N.M., SooHoo, W.M., Dugas, J.L., Lee, D.M., and Borrok, P.S., 2018, Louisiana Barrier Island Comprehensive Monitoring Program—Habitat mapping: U.S. Geological Survey data release, https://doi.org/10.5066/F7XP7440.

ISSN 2331-1258 (online) 


\section{Acknowledgments}

This effort was funded by the Louisiana Coastal Protection and Restoration Authority's (CPRA) Barrier Island Comprehensive Monitoring program. We would like to thank Syed Khalil (CPRA) for numerous helpful discussions about the habitat mapping methods and analysis for this project. We thank John Barras for his assistance with the development of coastal reach boundaries for this effort. We are grateful to Hana Thurman (Cherokee Nation Technologies) for her assistance with designing the cover graphic. Finally, we thank Syed Khalil, Glen Curole (CPRA), Brady Couvillion (U.S. Geological Survey; USGS), and Richard Day (USGS) for reviewing this report. 



\section{Contents}

Acknowledgments ……...................................................................................................................

Abstract

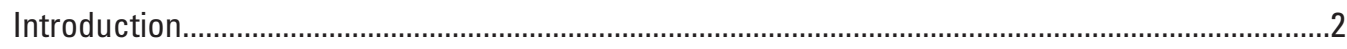

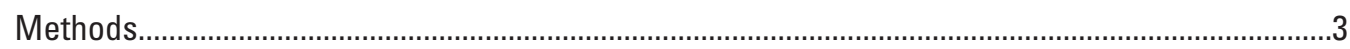

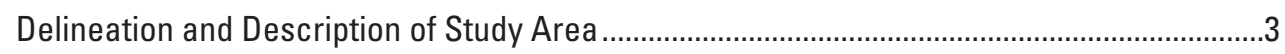

Hurricanes, Extreme Storms, and Restoration Efforts..........................................................

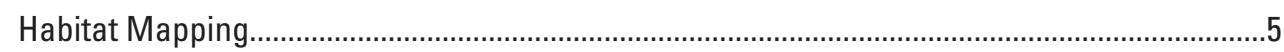

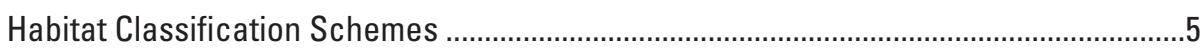

Source Data and Preprocessing .................................................................................

Elevation Uncertainty and Monte Carlo Simulations ........................................................

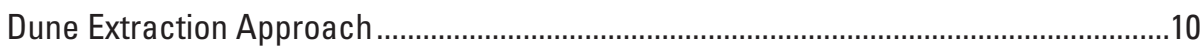

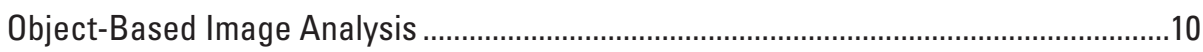

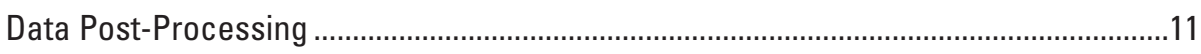

Habitat Classification Accuracy Assessment...................................................................11

Habitat Change and Accuracy Assessment .....................................................................12

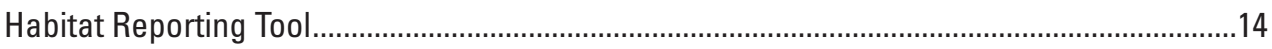

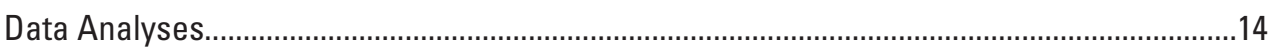

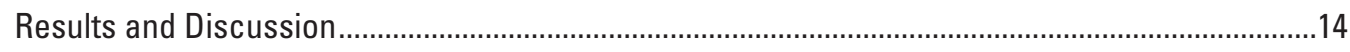

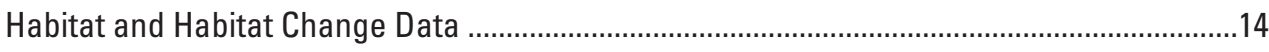

Habitat and Habitat Change Accuracy .............................................................................

BICM Region-Wide Habitat and Habitat Change ............................................................. 19

West Chenier Plain Region Habitat and Habitat Change ....................................................2

East Chenier Plain Region Habitat and Habitat Change........................................................26

Acadiana Bays Region Habitat and Habitat Change .............................................................30

Early Lafourche Delta Region Habitat and Habitat Change....................................................32

Late Lafourche Delta Region Habitat and Habitat Change ......................................................34

Modern Delta Region Habitat and Habitat Change ................................................................

Chandeleur Islands Region Habitat and Habitat Change ...........................................................39

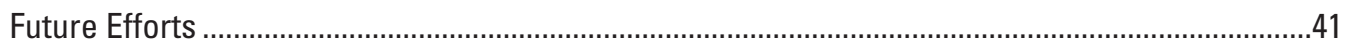

Summary

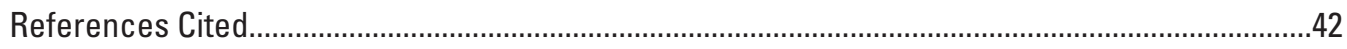

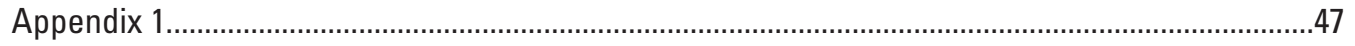

\section{Figures}

1. Map showing regions and reaches along the Louisiana Gulf of Mexico shoreline mapped during the 2008 and 2015-16 habitat mapping efforts for the Louisiana Barrier Island Comprehensive Monitoring Program..

2. Chart showing an overview of the Monte Carlo error propagation process for estimating the probability of a pixel being above or below a specific elevation threshold for digital elevation models for the Louisiana Barrier Island Comprehensive Monitoring Program habitat mapping effort along the Louisiana Gulf of Mexico shoreline. 
3. Example of workflow for using geographic object-based image analyses for habitat mapping for the Louisiana Barrier Island Comprehensive Monitoring Program

4. Chart showing an overview of the mapping process used for the barrier island habitat maps for the Louisiana Barrier Island Comprehensive Monitoring Program for the detailed scheme

5. Maps showing Louisiana Barrier Island Comprehensive Monitoring Program detailed habitat classes and general habitat classes, 2016, Whiskey Island, Louisiana

6. Map showing Louisiana Barrier Island Comprehensive Monitoring Program land/water-based change classes for 2008-16 for Whiskey Island, Louisiana

7. Map showing Louisiana Barrier Island Comprehensive Monitoring Program inundation zone-based habitat change classes for 2008-16 for Whiskey Island, Louisiana

8. Images showing the overview of the functionality of the Louisiana Barrier Island Comprehensive Monitoring Program Habitat Reporting Tool

9. Graph showing percentages of habitat class areal coverage in the regions mapped during the Louisiana Barrier Island Comprehensive Monitoring Program habitat analyses, 2008 and 2015-16

10. Graph showing percentages of habitat class areal coverage in the West Chenier Plain region mapped during the Louisiana Barrier Island Comprehensive Monitoring Program, 2008 and 2015

11. Maps showing coverage of detailed habitat classes in an area of the West Chenier Plain region during 2008 and 2015, and paired oblique photographs showing Sabine Pass, 2006 and 2017

12. Graph showing the percentages of areal coverage for land/water change classes, by Louisiana Barrier Island Comprehensive Monitoring Program region.........26

13. Graph showing the percentages of areal coverage for inundation zone-based habitat change classes, by Louisiana Barrier Island Comprehensive Monitoring Program region

14. Graph showing percentages of habitat class areal coverage in the East Chenier Plain region mapped during the Louisiana Barrier Island Comprehensive Monitoring Program, 2008 and 2015

15. Maps showing coverage of detailed habitat classes in an area of the East Chenier Plain region during 2008 and 2015, and paired oblique photographs, 2006 and 2017.

16. Graph showing percentages of habitat class areal coverage in the Acadiana Bays region mapped during the Louisiana Barrier Island Comprehensive Monitoring Program, 2008 and 2015-16.

17. Maps showing coverage of detailed habitat classes in an area of the Acadiana Bays region during 2008 and 2015-16

18. Graph showing percentages of habitat class areal coverage in the Early Lafourche Delta region mapped during the Louisiana Barrier Island Comprehensive Monitoring Program, 2008 and 2016

19. Maps showing coverage of detailed habitat classes in an area of the Early Lafourche Delta region during 2008 and 2016, and paired oblique photographs, 2007 and 2017.

20. Graph showing percentages of habitat class areal coverage in the Late Lafourche Delta region mapped during the Louisiana Barrier Island Comprehensive Monitoring Program, 2008 and 2016 
21. Maps showing coverage of detailed habitat classes in an area of the Late Lafourche Delta region during 2008 and 2016, and paired oblique photographs, 2007 and 2017.

22. Graph showing percentages of habitat class areal coverage in the Modern Delta region mapped during the Louisiana Barrier Island Comprehensive Monitoring Program, 2008 and 2016

23. Maps showing coverage of detailed habitat classes in an area of the Modern Delta region during 2008 and 2016, and paired oblique photographs, 2007 and 2017 .....38

24. Graph showing percentages of habitat class areal coverage in the Chandeleur Islands region mapped during the Louisiana Barrier Island Comprehensive Monitoring Program, 2008 and 2016

25. Maps showing coverage of detailed habitat classes in an area of the Chandeleur Islands region during 2008 and 2016, and paired oblique photographs, 2006 and 2017.

\section{Tables}

1. Tropical cyclones within 125 nautical miles of either Lake Charles or New Orleans, Louisiana, from 2008 to 2016

2. Restoration projects along the Louisiana Gulf of Mexico shoreline, by Louisiana Barrier Island Comprehensive Monitoring Program region, 2009-16.

3. Louisiana Barrier Island Comprehensive Monitoring Program detailed and general habitat classification schemes used in habitat mapping efforts for the Louisiana Gulf of Mexico shoreline

4. Orthophotography date and lidar source data information for 2008 and 2015-16 habitat maps, by Louisiana Barrier Island Comprehensive Monitoring Program region

5. Louisiana Barrier Island Comprehensive Monitoring Program change product bins for the land/water and inundation zone-based habitat change products with associated BICM detailed habitat classes.

6. Louisiana Barrier Island Comprehensive Monitoring Program change classes for the land/water and inundation zone-based habitat change products

7. Accuracy assessment results for detailed habitat classes for 2008 and 2015-16, by Louisiana Barrier Island Comprehensive Monitoring Program region

8. Fuzzy accuracy assessment results for land/water change from 2008 to 2015-16, by Louisiana Barrier Island Comprehensive Monitoring Program region

9. Fuzzy accuracy assessment results for inundation zone-based habitat change classes for change from 2008 to 2015-16, by Louisiana Barrier Island Comprehensive Monitoring Program region.

10. Percent change for detailed habitat classes for 2008 and $2015-16$, by Louisiana Barrier Island Comprehensive Monitoring Program region. 


\section{Conversion Factors}

International System of Units to U.S. customary units

\begin{tabular}{|c|c|c|}
\hline Multiply & By & To obtain \\
\hline \multicolumn{3}{|c|}{ Length } \\
\hline centimeter $(\mathrm{cm})$ & 0.3937 & inch (in.) \\
\hline millimeter (mm) & 0.03937 & inch (in.) \\
\hline meter $(\mathrm{m})$ & 3.281 & foot $(\mathrm{ft})$ \\
\hline kilometer (km) & 0.6214 & mile (mi) \\
\hline kilometer (km) & 0.5400 & mile, nautical (nmi) \\
\hline meter $(\mathrm{m})$ & 1.094 & yard (yd) \\
\hline \multicolumn{3}{|c|}{ Area } \\
\hline square meter $\left(\mathrm{m}^{2}\right)$ & 0.0002471 & acre \\
\hline hectare (ha) & 2.471 & acre \\
\hline hectare (ha) & 0.003861 & square mile $\left(\mathrm{mi}^{2}\right)$ \\
\hline \multicolumn{3}{|c|}{ Flow rate } \\
\hline meter per year (m/yr) & 3.281 & foot per year ft/yr) \\
\hline millimeter per year (mm/yr) & 0.03937 & inch per year (in/yr) \\
\hline
\end{tabular}

\section{Datum}

Vertical coordinate information is referenced to the North American Vertical Datum of 1988 (NAVD 88), unless otherwise noted.

Horizontal coordinate information is referenced to the North American Datum of 1983 Universal Transverse Meter Zone 15 North (NAD 83 UTM 1N).

Elevation, as used in this report, refers to distance above the vertical datum, unless otherwise noted. 


\section{Abbreviations}

$\begin{array}{ll}\text { BICM } & \text { Barrier Island Comprehensive Monitoring } \\ \text { CIMS } & \text { Coastal Information Management System } \\ \text { CPRA } & \text { Coastal Protection and Restoration Authority } \\ \text { DEM } & \text { digital elevation model } \\ \text { EHWS } & \text { extreme high water springs tide level } \\ \text { ET } & \text { elevation threshold } \\ \text { GEOBIA } & \text { geographic object-based image analysis } \\ \text { HRT } & \text { Habitat Reporting Tool } \\ \text { IZB } & \text { inundation zone-based } \\ \text { lidar } & \text { light detection and ranging } \\ \text { MMU } & \text { minimum mapping unit } \\ \text { MSL } & \text { mean sea level } \\ \text { NDVI } & \text { normalized difference vegetation index } \\ \text { NOAA } & \text { National Oceanic and Atmospheric Administration } \\ \text { NTDE } & \text { North American Tidal Datum Epoch } \\ \text { PCA } & \text { principal components analysis } \\ \text { PDF } & \text { Portable Document Format } \\ \text { SD } & \text { standard deviation } \\ \text { TPI } & \text { topographic position index } \\ \text { USGS } & \text { U.S. Geological Survey }\end{array}$





\title{
Louisiana Barrier Island Comprehensive Monitoring Program: Mapping Habitats in Beach, Dune, and Intertidal Environments Along the Louisiana Gulf of Mexico Shoreline, 2008 and 2015-16
}

\author{
By Nicholas M. Enwright, 1 William M. SooHoo,2 Jason L. Dugas, ${ }^{1}$ Craig P. Conzelmann,1 Claudia Laurenzano, ${ }^{2}$ \\ Darin M. Lee, ${ }^{3}$ Kelly Mouton, ${ }^{2}$ and Spencer J. Stelly4
}

\section{Abstract}

Barrier islands, headlands, and coastal shorelines provide numerous valuable ecosystem goods and services, including storm protection and erosion control for the mainland, habitat for fish and wildlife, salinity regulation in estuaries, carbon sequestration in marshes, and areas for recreation and tourism. These coastal features are dynamic environments because of their position at the land-sea interface. Storms, wave energy, tides, currents, and relative sea-level rise are powerful forces that shape local geomorphology and habitat distribution. In order to make more informed decisions, coastal resource managers require insights into how these dynamic systems are changing through time.

In 2005, Louisiana's Coastal Protection and Restoration Authority, in partnership with the University of New Orleans and the U.S. Geological Survey, developed the Barrier Island Comprehensive Monitoring (BICM) Program. The goal of the BICM Program is to develop long-term datasets for habitat coverage, shoreline assessments, shoreline position, topobathymetric changes, and sediment characterization to assist with planning, designing, evaluating, and maintaining current and future barrier shorelines. The overall objectives of the study described in this report were to (1) map habitats for 2008 and 2015-16 for BICM coastal reaches and (2) map habitat change between these two time periods.

This report highlights the second phase of habitat analyses for the BICM Program. This work builds on a previous habitat analysis conducted by the University of New Orleans, which included the development of habitat maps for 1996/1998, 2001, 2004, and 2005, along with habitat change maps. For this current effort, a new 15-class habitat scheme

\footnotetext{
1U.S. Geological Survey.

${ }^{2}$ Cherokee Nation Technologies.

${ }^{3}$ Louisiana Coastal Protection and Restoration Authority.

${ }^{4}$ Stelly Consulting (for the U.S. Geological Survey).
}

was developed from the original BICM scheme to further delineate various dune habitats, including meadow habitat found along the backslopes of dunes, to distinguish between marsh and mangrove, and to distinguish between beach and unvegetated barrier flat habitats. Additionally, a geographic object-based image analysis-based mapping framework was used to incorporate relative topography and address elevation uncertainty in light detection and ranging data to assist with mapping dune and intertidal habitats.

For the entire BICM region, the area experiencing a change in a land/water category (that is, land gain or land loss) was 3.4 percent, of which, 59.2 percent was land gain and 40.8 percent was land loss. Areal coverages of meadow, mangrove, scrub/shrub, and vegetated dune increased from 2008 to 2015-16, whereas areal coverages of beach, grassland, and intertidal decreased. The decrease in intertidal, however, was largely due to differing water levels in the orthophotography between the two time periods. Regional analyses of habitat coverage and habitat change captured the dynamic nature of these systems and the effects of restoration efforts, most notably in the Late Lafourche Delta, Modern Delta, and Chandeleur Islands regions. For instance, in the Modern Delta region there was a marked increase in unvegetated flat, meadow, mangrove, scrub/shrub, beach, unvegetated dune, and vegetated dune. As a result, this region experienced the highest percent change for land/water classes (6.6 percent) with land gain accounting for much of this change (70.8 percent). In contrast, the Acadiana Bays region had the highest relative percent loss of all regions. The region had a percent change for land/water classes of 2.8 percent, of which, 79.7 percent was land loss.

The results of this study provide information about the areal coverage and distribution of habitats for two recent time periods and change over about an 8-year period. These data can be used to evaluate changes along the Louisiana Gulf of Mexico shoreline, including gradual changes caused by coastal processes, restoration actions, and (or) episodic events, such as hurricanes and extreme storms. 


\section{Introduction}

Barrier islands, headlands, and coastal shorelines are dynamic coastal environments that consist of wave-, wind-, and (or) tide-deposited sediments located along the estuarinemarine interface. These areas are composed of a diverse mixture of habitats, including beaches, dunes, intertidal marshes, intertidal flats, and coastal forests. Collectively, these coastal systems provide valuable ecosystem services, including storm protection and erosion control for the mainland, habitat for fish and wildlife, carbon sequestration in marshes, water catchment and purification, and areas for recreation and tourism (Sallenger, 2000; Feagin and others, 2010; Barbier and others, 2011). Yet, these environments face an uncertain future, particularly in the latter part of the 21 st century, as numerous coastal hazards, including hurricanes, extreme storms, accelerated sea-level rise, oil spills, and anthropogenic effects, may influence the future of these coastal systems (Pilkey and Cooper, 2014). In order to make more informed decisions, coastal resource managers require insights into how these dynamic systems are changing through time.

In particular, the Louisiana Gulf of Mexico shoreline protects extensive and valuable coastal wetlands from the erosional forces from high-energy waves and provides important habitat for many wildlife species, including critically designated habitats for two species of shorebirds, piping plovers and red knots, which are federally listed as threatened species. Louisiana's Gulf of Mexico shoreline is one of the fastest eroding shorelines in the United States (Byrnes and others, 2018), and protecting these fragile wetlands is critical because Louisiana is losing coastal wetlands at an alarming rate (Couvillion and others, 2017). Restoration efforts along Louisiana's Gulf of Mexico shoreline have been extensive (Coastal Protection and Restoration Authority, 2017), and understanding the performance and effects of these efforts, along with future needs, is imperative.

The importance and challenge of monitoring the Louisiana Gulf of Mexico shoreline led to the development of a comprehensive and holistic monitoring approach. In 2005, Louisiana's Coastal Protection and Restoration Authority (CPRA), in partnership with the University of New Orleans and the U.S. Geological Survey (USGS), developed the Barrier Island Comprehensive Monitoring (BICM) Program. The goal of the BICM Program is to provide long-term datasets to assist with planning, designing, evaluating, and maintaining current and future barrier shorelines. The program uses historical and contemporary data collections to assess and monitor changes in the subaerial and subaqueous extents, habitat types, sediment texture and geotechnical properties, environmental processes, and vegetation composition. Current examples of BICM datasets include (1) oblique photography along the shoreline with periodic comparisons; (2) coastwide shoreline delineation and change analysis; (3) topography data and change; (4) bathymetry data and change; (5) habitat delineation with habitat and land/water change; and (6) surficial sediment composition and change. The BICM Program is currently completing its second phase of data collection and analyses. For information on the initial analyses of the BICM Program, which spanned from about 2006 to 2010, see Kindinger and others (2013).

Geographers and remote sensing scientists produce maps to show how habitats on barrier islands, on headlands, and along the coastal shoreline are changing (Fearnley and others, 2009; Lucas and Carter, 2010; Kindinger and others, 2013; Jeter and Carter, 2015; Zinnert and others, 2016; Campbell and others, 2017; Enwright and others, 2019). Barrier island and coastal shoreline habitat monitoring often requires custom habitat maps because of several factors, including island size and the classification of unique geomorphology-based habitats, such as beach, dune, and unvegetated barrier flat (for example, overwash areas; Enwright and others, 2019).

The initial BICM habitat mapping effort, led by the University of New Orleans Institute for Environmental Sciences, produced habitat maps with an eight-class habitat scheme for 1996/1998, 2001, 2004, and 2005 by using supervised and unsupervised classification of USGS digital orthophoto quarter quads and QuickBird satellite orthophotography (Fearnley and others, 2009). The habitat datasets from different years were compared to determine habitat changes. Pixel-based mapping approaches, such as the one used by the initial BICM habitat mapping effort, classify each individual pixel in the orthophotography and are commonly used to map habitats on barrier islands and along coastal shorelines (Lucas and Carter, 2010, 2013; Timm and McGarigal, 2012; McCarthy and Halls, 2014).

Geographic object-based image analysis (GEOBIA; Blaschke and others, 2014) is a mapping framework process that involves the development of objects from orthophotography and then classifying the orthophotography based on object-level statistics (for example, mean value and [or] standard deviation for a spectral band of the orthophotography, such as the near-infrared band). This approach is commonly used for mapping coastal habitats (Heumann, 2011; Dronova, 2015) and barrier islands, headlands, and coastal shorelines (Hantson and others 2012; Brownett and Mills, 2017; Campbell and others, 2017; Sturdivant and others, 2017; Enwright and others, 2019). While supervised and unsupervised algorithms can be used with GEOBIA (Timm and McGarigal, 2012; Dronova, 2015; Campbell and others, 2017), researchers often use a rule-based approach that classifies habitat types in a stepwise fashion by using photointerpretation and expert knowledge (Gao and others, 2004; Myint and others, 2011; O'Neil-Dunne and others, 2014; Dronova, 2015; Brownett and Mills, 2017).

Geomorphology is an important feature for habitat delineation on barrier islands and along the coastal shoreline. Increasingly, researchers are extracting relative topography information from light detection and ranging (lidar) data to delineate dune habitats (Wernette and others, 2016; Halls and others, 2018; Enwright and others, 2019) and using bareearth digital elevation models (DEMs) developed from lidar data and tide data for automated delineation of intertidal 
and supratidal/upland habitats (McCarthy and Halls, 2014; Brownett and Mills, 2017; Halls and others, 2018). The level of uncertainty from data collected with conventional aerial topographic lidar systems has been found to be as high as 60 centimeters $(\mathrm{cm})$ in densely vegetated emergent wetlands throughout the United States (Medeiros and others, 2015; Buffington and others, 2016; Enwright and others, 2018b). For habitat mapping efforts, the vertical uncertainty is often left unaddressed because of the lack of detailed error information. Yet, the level of uncertainty becomes critical when studying low-relief environments, including barrier islands, where centimeters can make a difference in the exposure to physically demanding abiotic conditions (for example, inundation, salt spray, wave energy). These challenges were addressed in a GEOBIA habitat mapping framework developed for a recent habitat mapping effort for Dauphin Island, Alabama (Enwright and others, 2019), which was modified for this study. For more details about mapping habitats on barrier islands and along coastal shorelines, see Enwright and others (2019).

For the second phase of the BICM habitat analyses, the USGS, in cooperation with the CPRA, built on the past efforts by the BICM Program (Fearnley and others, 2009) to develop habitat datasets for 2008 and 2015-2016 and assess habitat change between these time periods. In addition to using the GEOBIA habitat mapping framework (Enwright and others, 2019), we also developed a new 15-class habitat scheme. This scheme expanded the eight-class scheme used in previous BICM habitat mapping efforts (Fearnley and others, 2009). The additional classes developed in the new classification scheme were primarily used to further delineate various dune habitats, including meadow habitat found along the backslopes of dunes, to distinguish between marsh and mangrove, and to distinguish between beach and unvegetated barrier flat habitats. To ensure comparability between this effort and previous BICM map products, we crosswalked the new habitat classification scheme to the eight-class scheme used in previous BICM habitat mapping efforts.

One challenge with large-scale habitat mapping efforts is the availability of efficient and effective data visualization and distribution. To be most effective, data products should be available to resource decision managers, the scientific community, and the general public. In response, the USGS Wetland and Aquatic Research Center's Advanced Application Team developed a web-based reporting tool (https://warcapps.usgs.gov/bicm) to aid in the visualization and dissemination of habitat and habitat change data and maps via web-based visualization and reporting.

The data developed through this effort provide a snapshot of coastal habitats along the Louisiana Gulf of Mexico shoreline that can be combined with other maps to monitor these valuable natural resources over time. Specifically, the results of this effort will help provide information on the areal coverage and distribution of habitats for two recent time periods and serve as an updated baseline for evaluating changes, including gradual changes caused by coastal processes, restoration actions, and (or) episodic events, such as hurricanes and extreme storms. As previously mentioned, restoration efforts along Louisiana's Gulf of Mexico shoreline have been extensive (CPRA, 2017), but monitoring these restoration efforts through habitat mapping is a critical part of the restoration process. For example, habitat maps are needed to determine if the efforts are meeting their intended goals (that is, delivering various ecosystem goods and services) and (or) if adaptive management actions are required to maintain the restoration benefits.

\section{Methods}

\section{Delineation and Description of Study Area}

The study area for this effort spans much of Louisiana's Gulf of Mexico shoreline (fig. 1). The BICM Program has two nested levels for habitat analyses: BICM reaches and BICM regions, which are composed of a specific number of adjacent reaches. Specifically, the study area includes 30 reaches and covers 7 BICM regions: West Chenier Plain, East Chenier Plain, a portion of Acadiana Bays, Early Lafourche Delta, Late Lafourche Delta, Modern Delta, and Chandeleur Islands. For this effort, the BICM Program team conducted some minor boundary modifications of habitat mapping reaches used in prior efforts (Fearnley and others, 2009; Kindinger and others, 2013) to ensure the reach extents were optimized for assessing change through time. Reaches were refined based on historical data (for example, shoreline data, historical topographic maps, historical orthophotography, and satellite orthophotography). In general, the reaches cover the nearshore water of the Gulf side of the shoreline to about 4 kilometers $(\mathrm{km})$ inland. These new boundaries were created by the BICM Program in order to allow for potential erosion and shoreline change over the next 50 or so years based on BICM historical shoreline position, historical aerial photographs, and satellite orthophotography.

The Louisiana Gulf Coast has two distinct geomorphic zones (not shown): the Chenier Plain (fig. 1, West Chenier Plain region to Acadiana Bays region) and the Deltaic Plain (fig. 1, Early Lafourche Delta region to Chandeleur Islands region). In general, the Louisiana Gulf Coast geomorphology has largely been shaped by sea-level fluctuations and delta lobe switching by the Mississippi River (Penland and Suter, 1989; Kindinger and others, 2013). The Chenier Plain consists of alternating sand and shell-rich ridges (that is, cheniers) and marshes, which were formed by periods of mudflat progradation and shoreline erosion during delta lobe switching of the Mississippi River, along with sedimentation from local rivers (Penland and Suter, 1989). Barrier islands occur along the Deltaic Plain of coastal Louisiana. These islands have been developed by episodes of delta building (that is, sedimentation) and then abandonment (Penland and Suter, 1989). Along the Deltaic Plain, there are examples of Penland's threestage transgressive barrier island model (Penland and others, 


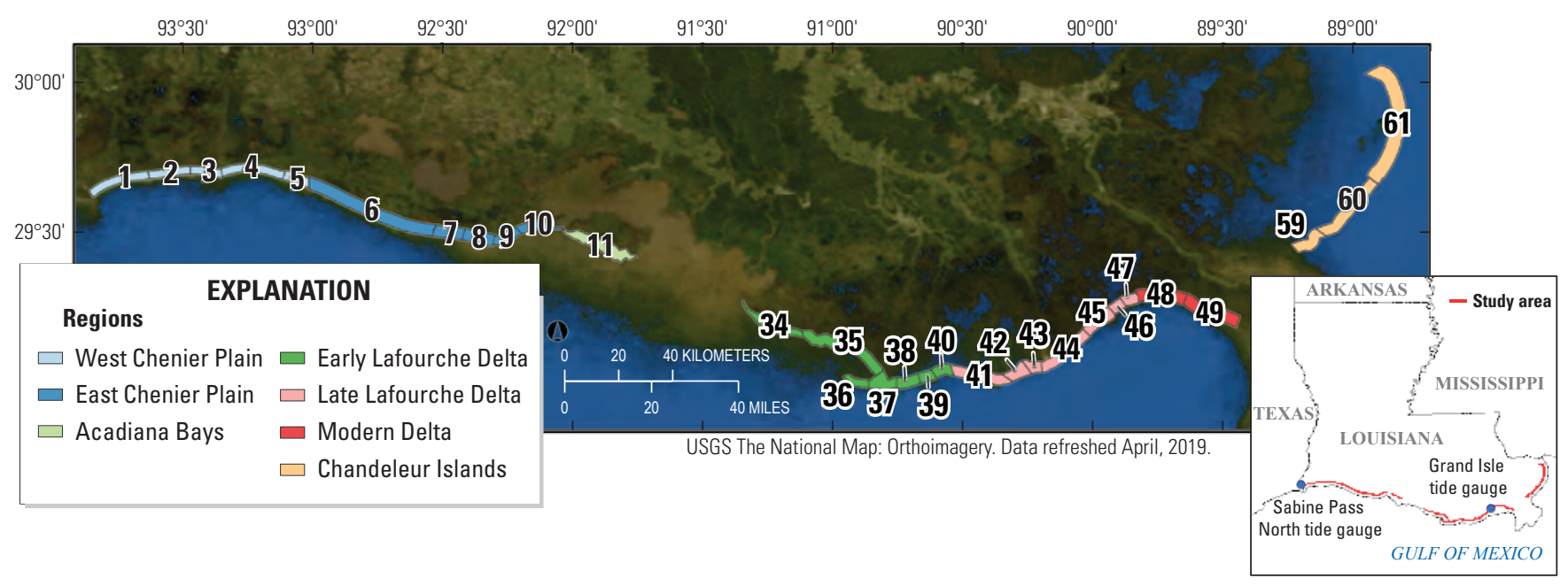

\begin{tabular}{|c|c|c|c|c|}
\hline Region & $\begin{array}{c}\text { Region area } \\
\text { (hectares) }\end{array}$ & Reach & Reach name & $\begin{array}{c}\text { Reach area } \\
\text { (hectares) }\end{array}$ \\
\hline \multirow[t]{5}{*}{ West Chenier Plain } & $25,610.50$ & 1 & Johnsons Bayou & $6,910.48$ \\
\hline & & 2 & Oceanview Beach & $4,668.72$ \\
\hline & & 3 & Holly Beach & $3,528.15$ \\
\hline & & 4 & Hackberry Beach & $7,092.27$ \\
\hline & & 5 & Mermentau River & $3,410.88$ \\
\hline \multirow[t]{5}{*}{ East Chenier Plain } & $40,428.60$ & 6 & Rockefeller Refuge & $22,431.98$ \\
\hline & & 7 & Mulberry Island & $4,969.52$ \\
\hline & & 8 & Freshwater Bayou & $5,151.55$ \\
\hline & & 9 & Chenier Au Tigre & $3,602.71$ \\
\hline & & 10 & Rainey Refuge & $4,272.84$ \\
\hline Acadiana Bays & $9,337.25$ & 11 & Marsh Island & $9,337.25$ \\
\hline \multirow[t]{7}{*}{ Early Lafourche Delta } & $36,261.27$ & 34 & Point Au Fer Island & $6,958.93$ \\
\hline & & 35 & Oyster Bayou to Caillou Boca & $13,027.66$ \\
\hline & & 36 & Raccoon Island & $2,725.30$ \\
\hline & & 37 & Whiskey Island & $4,860.11$ \\
\hline & & 38 & Trinity Island & $3,485.11$ \\
\hline & & 39 & East Island & $2,296.54$ \\
\hline & & 40 & Wine Island & $2,907.62$ \\
\hline \multirow{7}{*}{ Late Lafourche Delta } & $32,786.48$ & 41 & Timbalier Island & $8,374.07$ \\
\hline & & 42 & East Timbalier Island & $3,834.82$ \\
\hline & & 43 & West Belle Pass & $2,412.52$ \\
\hline & & 44 & Caminada Headland & $8,527.62$ \\
\hline & & 45 & Grand Isle & $5,118.41$ \\
\hline & & 46 & West Grand Terre & $2,145.23$ \\
\hline & & 47 & East Grand Terre & $2,373.81$ \\
\hline \multirow{2}{*}{ Modern Delta } & $17,910.72$ & 48 & Chaland Headland & $8,085.60$ \\
\hline & & 49 & Shell Island & $9,825.12$ \\
\hline \multirow[t]{3}{*}{ Chandeleur Islands } & $43,131.73$ & 59 & Breton Island & $5,188.16$ \\
\hline & & 60 & Grand Gosier and Curlew Islands & $11,597.67$ \\
\hline & & 61 & North Chandeleur Islands & $26,345.89$ \\
\hline $\begin{array}{l}\text { Entire BICM habitat } \\
\text { region }\end{array}$ & $205,466.55$ & & & \\
\hline
\end{tabular}

Figure 1. Regions and reaches along the Louisiana Gulf of Mexico shoreline mapped during the 2008 and 2015-16 habitat mapping efforts for the Louisiana Barrier Island Comprehensive Monitoring (BICM) Program. 
1988) (1) active delta (for example, the Wax Lake Delta); (2) erosional headland with flanking barriers (for example, Caminada Headland); (3) barrier island arc (for example, northern Chandeleur Islands); and (4) inner shelf shoals (for example, Ship Shoal). For more information on the subsurface geologic framework of the BICM study area, see Kindinger and others (2013).

\section{Hurricanes, Extreme Storms, and Restoration Efforts}

Hurricanes can substantially change composition and distribution of habitats along the Louisiana Gulf of Mexico shoreline. Byrnes and others (2018) used a National Oceanic and Atmospheric Administration (NOAA) cyclone database (NOAA, 2019a) to identify the paths of historical hurricanes and tropical storms that made landfall in or near coastal Louisiana from 1854 to 2015 . These tropical cyclones (that is, hurricanes and tropical storms) were generally assigned to BICM regions. For example, tropical cyclones that made landfall within about 125 nautical miles of Lake Charles were assigned to the regions in the Chenier Plain geomorphic zone, and cyclones that made landfall within 125 nautical miles of New Orleans were assigned to the regions in the Deltaic Plain geomorphic zone. No tropical cyclones occurred in 2016 within the respective 125-nautical-mile areas (table 1; NOAA, 2019a).

Restoration projects on barrier islands and along Louisiana Gulf of Mexico shoreline have been done to help offset coastal forces such as extreme waves and storms. Table 2 lists 21 restoration projects that were constructed between 2009 and 2016. Information on these restoration projects can be found in the CPRA's Coastal Information Management System (CIMS; https://cims.coastal.la.gov/). In this report, we will loosely connect regional habitat change analyses with hurricane and extreme storm events and restoration efforts (for example, a large increase in marsh habitat could be from a marsh restoration effort that occurred in that region).

\section{Habitat Mapping}

\section{Habitat Classification Schemes}

One challenge with a long-term monitoring program, such as BICM, is how to best to deal with opportunities that arise from technological advancements related to source data availability and characteristics and data processing. For this effort, we built on the habitat classification scheme used in previous BICM habitat mapping efforts (Fearnley and others, 2009) to develop a new habitat classification scheme (table 3). Hereinafter, the new classification scheme is referred to as the BICM "detailed" habitat classification scheme, and the original BICM habitat classification scheme is called the BICM "general" habitat classification scheme. The additional classes developed in the detailed scheme are primarily used to delineate dune habitats, including meadow habitat on the back slopes of dunes, to distinguish between marshes and mangroves, and to distinguish between beach and unvegetated barrier flat habitats. Researchers have begun extracting relative topography from elevation data for dune delineation (Wernette and others, 2016; Halls and others, 2018; Enwright and others, 2019), which has allowed the opportunity to enhance the BICM classification scheme by adding geomorphology-based habitats, such as vegetated dune and unvegetated dune, which were previously classified as barrier vegetation or bare land, respectively, for the initial BICM habitat mapping effort (Fearnley and others, 2009). In the absence of extreme freezes, black mangroves can often outcompete and expand at the expense of graminoids (for example, Spartina alterniflora or Juncus roemerianus) in tidal saline wetland systems (Osland and others, 2013), which provided critical rationale for delineating mangroves and marshes as separate classes. Currently,

Table 1. Tropical cyclones (that is, hurricanes and tropical storms) within 125 nautical miles of either Lake Charles or New Orleans, Louisiana, from 2008 to 2016 (National Oceanic and Atmospheric Administration, 2019a). Table adapted from Byrnes and others (2018) with permission.

[WC, West Chenier Plain; AB, Acadiana Bays; CI, Chandeleur Islands; --, not applicable]

\begin{tabular}{clllc}
\hline $\begin{array}{c}\text { Regions } \\
\text { (fig .1) }\end{array}$ & \multicolumn{1}{c}{ Cyclone name } & Year & Date(s) of cyclone within buffer & $\begin{array}{c}\text { Saffir-Simpson hur- } \\
\text { ricane wind scale } \\
\text { category at landfall }\end{array}$ \\
\hline WC to AB & Tropical Storm Edouard & 2008 & August 3-6 & -- \\
& Hurricane Gustav & 2008 & August 25-September 5 & 2 \\
& Hurricane Ike & 2008 & September 1-15 & 2 \\
& Tropical Storm Lee & 2011 & September 2-6 & -- \\
AB to CI & Hurricane Gustav & 2008 & August 25-September 5 & 2 \\
& Tropical Storm Lee & 2011 & September 2-6 & - \\
& Hurricane Isaac & 2012 & August 20-September 1 & 1 \\
\hline
\end{tabular}


Table 2. Restoration projects along the Louisiana Gulf of Mexico shoreline, by Louisiana Barrier Island Comprehensive Monitoring Program region, 2009-16. Table adapted from Byrnes and others (2018) with permission.

[WC, West Chenier Plain; EC, East Chenier Plain; ELD, Early Lafourche Delta; LLD, Late Lafourche Delta; MD, Modern Delta; CI, Chandeleur Islands]

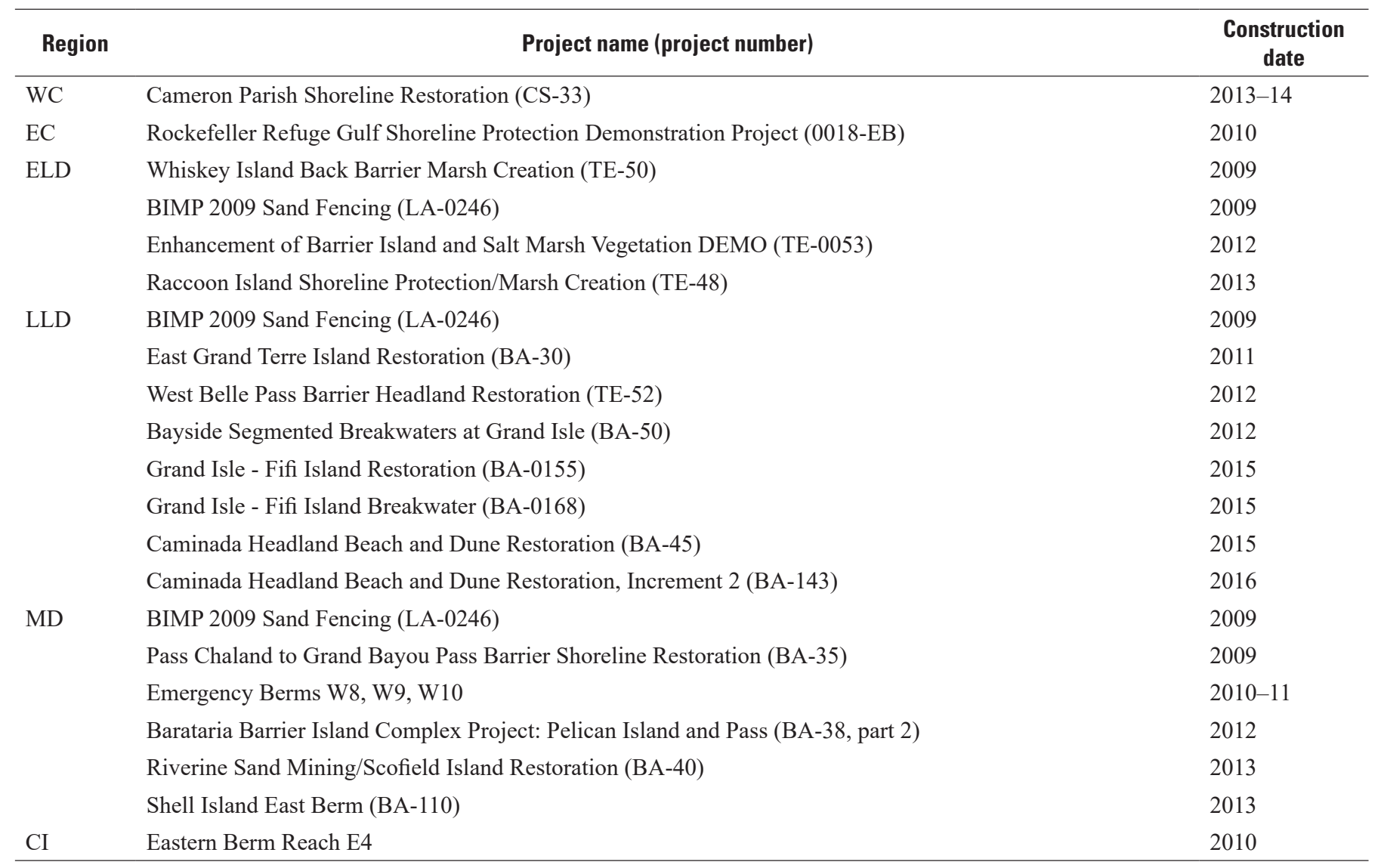

no standardized black mangrove habitat data have been developed for coastal Louisiana, so these data can also help fill an important data gap. To ensure comparability between this effort and previous BICM map products, we have crosswalked the detailed habitat classes to general habitat classes previously used by Fearnley and others (2009). In other words, the results with the general habitat classes included in this report and associated products were not directly interpreted by using the methodology discussed below, but instead were derived from a direct linkage to detailed classes (table 3).

\section{Source Data and Preprocessing}

Orthophotography served as the primary data source for BICM habitat maps. We used USGS 1-meter (m) four-band color-infrared orthophotography acquired in 2008, 2015, and 2016 (table 4). Orthophotography from 2008 covered the entire study area, whereas orthophotography from 2015 covered the West Chenier Plain, East Chenier Plain, and the western half of Acadiana Bays. The orthophotography from 2016 covered the eastern half of Acadiana Bays eastward through the Chandeleur Islands (fig. 1). As a result, the later dates of the habitat maps were 2015 for the West Chenier Plain and East Chenier Plain regions, 2015-16 for the Acadiana Bays region, and 2016 for the remaining regions to the east.

Seamless mosaics were developed for each reach. Because our effort included spatial change detection, it was important to ensure that orthophotography for each date was co-registered (that is, locations in one image are in the same location as in another image from a different date). We used image matching to register the 2015 and 2016 orthophotography to 2008. This is a challenging process on barrier islands and coastal settings because of the limited amount of fixed or nonmoving features, such as roads or structures. To ensure that we had enough well-spaced control points, we often used areas with similar texture and shape, such as the center of a circular patch of vegetation that can be easily detected in the orthophotography for both time periods. On average, we used 30 control points and either second- or third-order polynomial models to georeference the 2015 and 2016 orthophotography to match the 2008 with an average root mean square error of $0.93 \mathrm{~m}$.

We applied a local pass filter (that is, 3 pixels by 3 pixels) to reduce noise in the orthophotography. Next, we used the filtered orthophotography to calculate a normalized difference 
Table 3. Louisiana Barrier Island Comprehensive Monitoring (BICM) Program detailed and general habitat classification schemes used in habitat mapping efforts for the Louisiana Gulf of Mexico shoreline.

[--, not applicable]

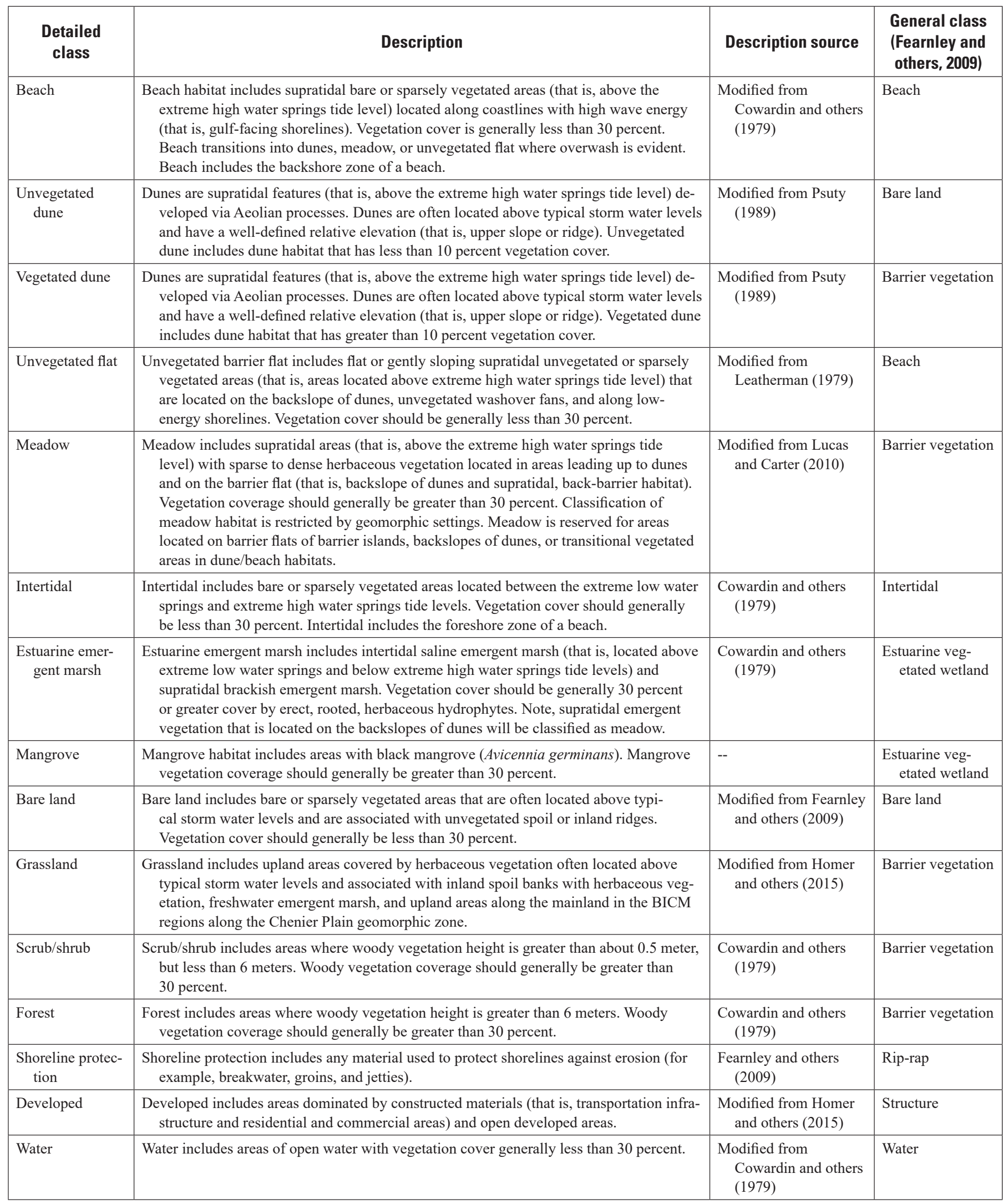


Table 4. Orthophotography date and lidar source data information (that is, date, digital elevation model [DEM] spatial resolution, and source) for 2008 and 2015-16 habitat maps, by Louisiana Barrier Island Comprehensive Monitoring (BICM) Program region.

[lidar, light detection and ranging; WC, West Chenier Plain; m, meter; USGS, U.S. Geological Survey; CoNED, Coastal National Elevation Database; EC, East Chenier Plain; USACE, U.S. Army Corps of Engineers; JALBTCX, Joint Airborne Lidar Bathymetry Technical Center for Expertise; AB, Acadiana Bays; ELD, Early Lafourche Delta; LLD, Late Lafourche Delta; MD, Modern Delta; CI, Chandeleur Islands. For full lidar DEM details, see metadata for BICM regional habitat classification datasets (Enwright and others, 2018a)]

\begin{tabular}{|c|c|c|c|c|c|c|c|c|}
\hline \multirow[b]{2}{*}{$\begin{array}{l}\text { Region } \\
\text { (fig. 1) }\end{array}$} & \multicolumn{4}{|c|}{2008 Habitat maps } & \multicolumn{4}{|c|}{ 2015-16 Habitat maps } \\
\hline & $\begin{array}{c}\text { Ortho- } \\
\text { photo- } \\
\text { graphy } \\
\text { date }\end{array}$ & $\begin{array}{l}\text { Lidar data } \\
\text { date(s) }\end{array}$ & $\begin{array}{l}\text { DEM spatial } \\
\text { resolution }\end{array}$ & Lidar data source & $\begin{array}{l}\text { Ortho- } \\
\text { photo- } \\
\text { graphy } \\
\text { date(s) }\end{array}$ & $\begin{array}{l}\text { Lidar data } \\
\text { date }\end{array}$ & $\begin{array}{l}\text { DEM spatial } \\
\text { resolution }\end{array}$ & $\begin{array}{l}\text { Lidar data } \\
\text { source }\end{array}$ \\
\hline WC & 2008 & 1999-2009 & $3-\mathrm{m}$ & USGS CoNED & 2015 & 2017 & $1-\mathrm{m}$ & USGS \\
\hline \multirow[t]{2}{*}{ EC } & 2008 & 1999-2011 & $3-\mathrm{m}$ & USGS CoNED & 2015 & 2017 & $1-\mathrm{m}$ & USGS \\
\hline & & 2009 & $3-\mathrm{m}$ & USACE JALBTCX & & & & \\
\hline $\mathrm{AB}$ & 2008 & 2011 & $3-\mathrm{m}$ & USGS & $2015-16$ & 2017 & $1-\mathrm{m}$ & USGS \\
\hline \multirow[t]{2}{*}{ ELD } & 2008 & 2010 & $3-\mathrm{m}$ & USACE JALBTCX & 2016 & 2015 & $3-\mathrm{m}$ & USGS \\
\hline & & 2011 & $3-\mathrm{m}$ & USGS & & & & \\
\hline \multirow[t]{2}{*}{ LLD } & 2008 & $2002-13$ & $3-\mathrm{m}$ & USGS CoNED & 2016 & 2013 & $3-\mathrm{m}$ & USGS \\
\hline & & 2010 & $3-\mathrm{m}$ & USACE JALBTCX & & 2015 & $3-\mathrm{m}$ & USGS \\
\hline \multirow[t]{2}{*}{ MD } & 2008 & $2002-13$ & $3-\mathrm{m}$ & USGS CoNED & 2016 & 2013 & $3-\mathrm{m}$ & USGS \\
\hline & & 2010 & $3-\mathrm{m}$ & USACE JALBTCX & & & & \\
\hline CI & 2008 & $2005-12$ & $3-\mathrm{m}$ & USGS CoNED & 2016 & 2015 & $3-\mathrm{m}$ & USGS \\
\hline
\end{tabular}

vegetation index (NDVI; eq. 1; Rouse and others, 1974), which is an index for vegetation greenness. The equation for NDVI is as follows:

$$
N D V I=\frac{N I R-R E D}{N I R+R E D}
$$

where
NIR is the near-infrared band of the orthophotography, and
$R E D \quad$ is the red band of the orthophotography.

We also conducted principal components analyses (PCA) of the filtered four-band aerial orthophotography. The application of PCA to nonspatial data produces "new" orthophotography that is a linear combination of the input data. In other words, this process creates a "new" four-band raster dataset in which the first one or two bands account for the most variance in the original image.

As previously mentioned, lidar data provided important information for coastal geomorphology. For each reach and period (that is, 2008, 2015, and 2016), we used the best available bare-earth lidar-based DEMs with relation to the orthophotography date. The spatial resolution for the majority of the DEMs was $3 \mathrm{~m}$; however, some 1-m DEMs were used for the Chenier Plain and Acadiana Bays regions for the 2015-16 habitat mapping effort. We transformed the elevation datasets from the North American Vertical Datum of 1988 to local mean sea level by using NOAA's VDatum version 3.1
(Parker, 2003). Extensive coastal habitat mapping efforts, such as this one, require the use of the best available data. One challenge with lidar data is that over time lidar data acquisitions may be captured with an increasingly higher sampling density, which may result in incremental quality increases over time (Heidemann, 2018). Additionally, lidar data are often collected less frequently than orthophotography. As a result, there may sometimes be temporal lags between the orthophotography, the primary data source for this effort, and other ancillary data, such as lidar data (table 4). In these cases, we assumed there were no major differences in topography between the two time periods unless we noticed obvious changes between the orthophotography and the DEM (for example, major beach erosion or spit migration). We used photointerpretation of the orthophotography for mapping habitats in areas with obvious disagreement between the orthophotography and the DEM. A potential implication of this approach is that some areas that were mapped as a certain habitat may be incorrect if there were substantial changes in elevation and relative topography that could not be detected by photointerpretation. In other words, an area may be mapped as unvegetated dune based on analysis of the orthophotography and lidar data; however, an overwash event that occurred since the lidar data were acquired could have resulted in the area actually being unvegetated flat and not unvegetated dune (that is, commission errors for unvegetated dune and omission errors for unvegetated flat). For mapping habitats for the Caminada Headland 
reach for 2016, we also used restoration project as-built data (that is, engineering design details) for information on the beach/dune restoration engineering design whenever restoration features were not included in the best available DEM. Esri ArcMap 10.5-10.7 (Redlands, California) was used for spatial analyses for this effort.

\section{Elevation Uncertainty and Monte Carlo Simulations}

Several elevation derivatives were developed to assist with habitat mapping of various classes, including intertidal zone habitats (estuarine emergent marsh, mangrove, and intertidal detailed classes) and dune habitats. Studies have found that elevation data uncertainty in densely vegetated areas such as marsh can have a vertical error as high as $60 \mathrm{~cm}$ (Medeiros and others, 2015; Buffington and others, 2016; Enwright and others, 2018b). One traditional approach for addressing vertical uncertainty in DEMs is the use of Monte Carlo simulations (Hunter and Goodchild, 1995; Wechsler and Kroll, 2006). For example, Monte Carlo simulations can be used to propagate error and determine the probability that the elevation is below a specific threshold for the set of iterations. Liu and others (2007) used Monte Carlo simulations and error reported from lidar metadata to delineate the mean high water shoreline on the Bolivar Peninsula in Texas.

While vertical accuracy estimates are contained within the DEM metadata, these estimates are often representative of the entire acquisition footprint, which includes a large area and many different land cover types and geomorphic settings. As a result, this can be an underestimate of the DEM vertical uncertainty for specific coastal habitat types, such as vegetated intertidal wetlands and dunes. For this reason, we used a relative accuracy assessment of a 2015 1-m lidar-based DEM for Dauphin Island, Ala., for error and bias estimates for intertidal and wetland vegetation and dunes (Enwright and others, 2018b, 2019).

Intertidal wetlands are situated above the extreme low water spring and below the extreme high water springs (EHWS) tidal datum (Cowardin and others, 1979). We defined EHWS as the highest astronomical tide for a given tide gauge during the most recent North American Tidal Datum Epoch (NTDE; 1983-2001) or the 5-year epoch for gauges in areas with rapid relative sea-level rise. We used data from NOAA tide gauges to determine the EHWS from the Sabine Pass North gauge (Station ID: 8770570; fig. 1; EHWS = $0.40 \mathrm{~m}$ relative to mean sea level [MSL] based on observations from the recent NTDE) for West Chenier to Acadiana Bays regions and the Grand Isle gauge (Station ID: 8761724; fig. 1; EHWS $=0.39 \mathrm{~m}$ relative to MSL based on observations during 2012-16) for Early Lafourche Delta to Chandeleur Islands regions.
Storms play a large role in the regulation of morphology and habitats along the Louisiana Gulf of Mexico shoreline, which consists of wave-dominated barrier islands, headlands, and shorelines (McBride and others, 2013). We used NOAA's extreme water analyses for estimates on reoccurrence intervals for extreme water levels for the two tide gauges (Zervas, 2013). These analyses developed reoccurrence intervals for the tide gauges based on observations between 1966 and 2010. Similar to efforts for Dauphin Island, Ala. (Enwright and others, 2019), we used the extreme water level with a 10-percent annual exceedance probability for NTDE or recent 5-year tidal datum epoch (1.20 m relative to MSL for Sabine Pass North and $1.11 \mathrm{~m}$ relative to MSL for Grand Isle) for the 2008 habitat mapping effort and an updated estimate for 2015 for the 2015-16 habitat mapping effort (1.30 m relative to MSL for Sabine Pass North and $1.16 \mathrm{~m}$ relative to MSL for Grand Isle) to account for relative sea-level rise (NOAA, 2016a, b).

To address elevation uncertainty, we used Monte Carlo simulations to estimate the probability of a pixel being above or below the previously mentioned elevation thresholds. The results of this process were probabilistic rasters that estimated the probability of a pixel being intertidal by using the EHWS elevation threshold with relative vertical error and bias for intertidal areas from Enwright and others (2019). Additionally, probabilistic rasters were developed to estimate the probability of an area being above the elevation associated with an extreme storm water level with a 10-percent annual exceedance by using extreme storm water levels from NOAA and the dune relative vertical error and bias estimates from Enwright and others (2019). Figure 2 shows the workflow used for the Monte Carlo simulations for each reach. The first step of the Monte Carlo simulations was to develop a random field with a mean $=0$ and a standard deviation of 0.5 . Next, a local filter was used to incorporate spatial autocorrelation. We multiplied the filtered random field by the error and bias estimates for the desired outcome (that is, intertidal relative vertical error for determining the probability of an area being intertidal and dune relative vertical error for the probability of an area being above the extreme storm water level). Next, we ran a logical operator to create a binary presence/absence raster based on whether pixels met the specific criteria related to the elevation threshold. This process was repeated 500 times for each Monte Carlo simulation to determine the probability of an area meeting the desired outcome for that simulation (that is, probability of being intertidal or probability of being above extreme storm water levels). Originally, we used 1,000 iterations for each Monte Carlo simulation; however, we reduced this number to 500 to increase computation efficiency, especially for large reaches, and to be consistent with the iteration count that was used for similar research on Dauphin Island, Ala. (Enwright and others, 2018b). For the Monte Carlo simulations, we resampled all 1-m DEMs that were used for the 2015-16 habitat maps to 3-m DEMs by using bilinear interpolation. The rationale for this was for consistency with the 2008 habitat 

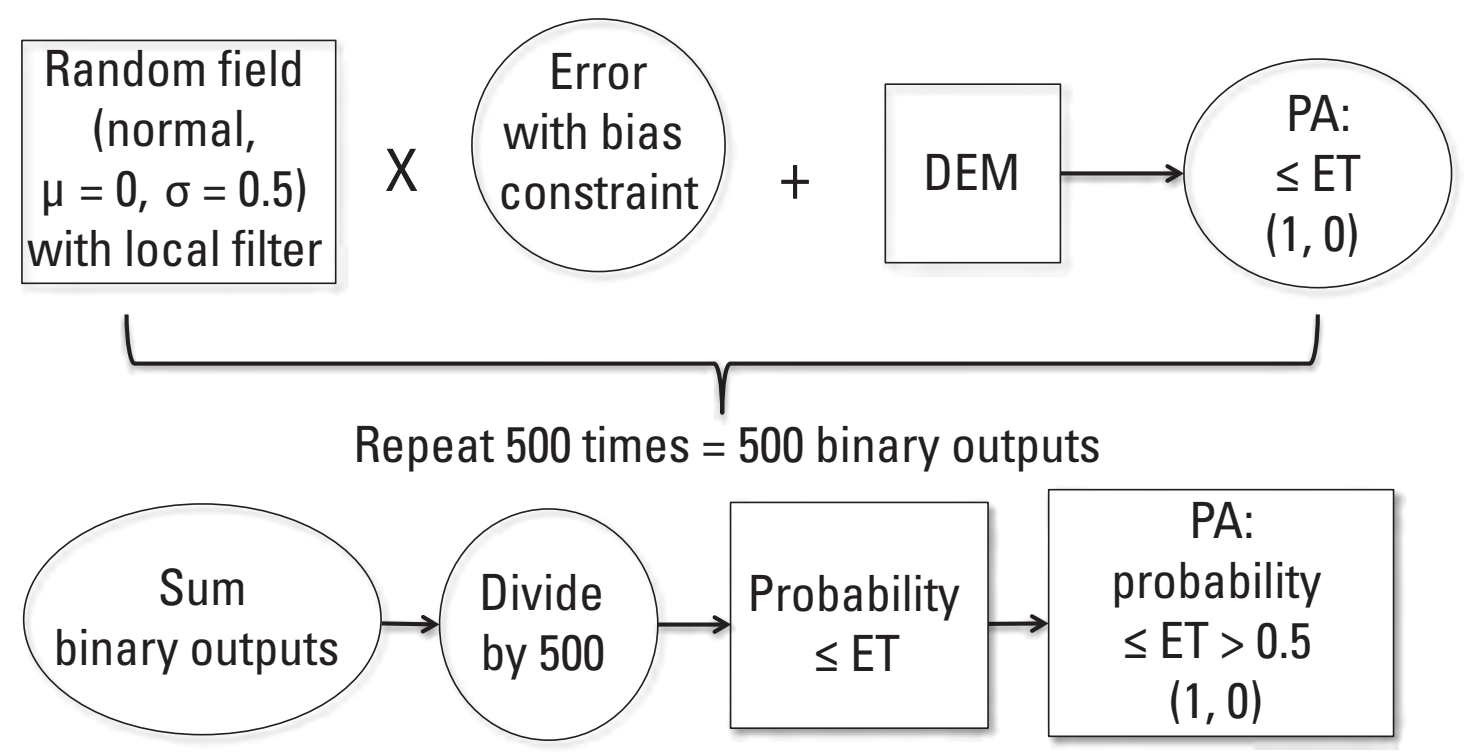

Figure 2. An overview of the Monte Carlo error propagation process for estimating the probability of a pixel being above or below a specific elevation threshold (that is, the elevation of extreme high water spring or the elevation of extreme water level with a 10-percent annual exceedance probability) for digital elevation models (DEMs) for the Louisiana Barrier Island Comprehensive Monitoring Program habitat mapping effort along the Louisiana Gulf of Mexico shoreline. [Modified from Enwright and others (2018b) with permission; $\mu$, mean; $\sigma$, standard deviation; PA, presence-absence; ET, elevation threshold]

map DEMs and for enhanced computational efficiency. For more information on the Monte Carlo analyses, see Enwright and others $(2017,2018 b, 2019)$.

\section{Dune Extraction Approach}

As previously mentioned, relative topography is helpful for delineating dunes. We used an approach similar to that of Wernette and others (2016) to help guide dune delineation by using relative relief. The topographic position index (TPI) was developed by comparing the elevation for a pixel with the mean for a user-defined neighborhood (Weiss, 2001; De Reu and others, 2013). We estimated the TPI for a circular 30-m neighborhood. The optimal neighborhood size was determined through trial and error and visual interpretation of the TPI outputs and cross-shore topographic profiles. Additionally, this neighborhood size was used for similar analyses on Dauphin Island, Ala. (Enwright and others, 2019). The mean and standard deviation (SD) for the region of interest (that is, the land portion of a given reach) of the relative difference between the center pixel and the mean neighborhood value were used to identify upper slopes and ridges. Upper slopes had a value between one-half of a SD and one SD from the regional mean, and ridges had a value that is greater than one SD from the regional mean (Weiss, 2001; De Reu and others, 2013). We eliminated ridges and upper slopes from the TPI data that had a probability at or below 0.5 for being below the extreme storm water level. Next, we used photointerpretation to manually edit the ridges and upper slopes to remove areas with disagreement between the DEM and orthophotography because of temporal differences or areas that were above extreme storm water levels and had relative topography, but were not dunes (for example, spoil banks). For more information on this process, see Enwright and others (2019).

\section{Object-Based Image Analysis}

We used a semiautomated approach to classify habitats on barrier islands, on headlands, and along coastal shorelines. We used multiresolution segmentation (Trimble, 2016) in Trimble eCognition 9.2 to segment the orthophotography into objects based on spectral similarities with regard to the orthophotography, derivatives of orthophotography, including the first two components of the PCA, NDVI, and spatial similarities based on elevation data. As done in similar studies, such as Myint and others (2011), we determined the optimal segmentation parameters (that is, bands, weights, scale of objects) by using a trial-and-error approach. We used a hierarchical approach to classify the image objects based on object-level statistics (fig. 3) and photointerpretation. First, we classified the objects as land or water. We then classified land objects into vegetated and unvegetated categories by trial and error by using level-slice thresholds for NDVI and near-infrared spectral object-level statistics (fig. 4). We used general knowledge-based thresholds and photointerpretation to further subdivide vegetated and unvegetated areas into habitats according to habitat definitions (table 3 ). For a given step, threshold-based rules were used to minimize omission and 
commission errors. We used the intertidal probabilistic rasters as a guide for habitat mapping for intertidal zone habitats. Generally, we considered areas with a probability of being below EHWS greater than 0.5 to have an intertidal hydrologic regime. In some cases, however, we also assigned areas to supratidal/upland habitats based on the visual inspection of the aerial photography. Because the DEMs we used were limited to only topographic lidar data, our elevation analyses for identifying intertidal areas were focused on identifying areas located between the MSL and the EHWS. We used photointerpretation to map intertidal areas below the MSL. Similarly, the edited TPI-based ridges and upper slopes were used as a guide for dune delineation. After applying general decision rules for each habitat in a stepwise fashion, we used photointerpetation to refine habitats through manual editing.

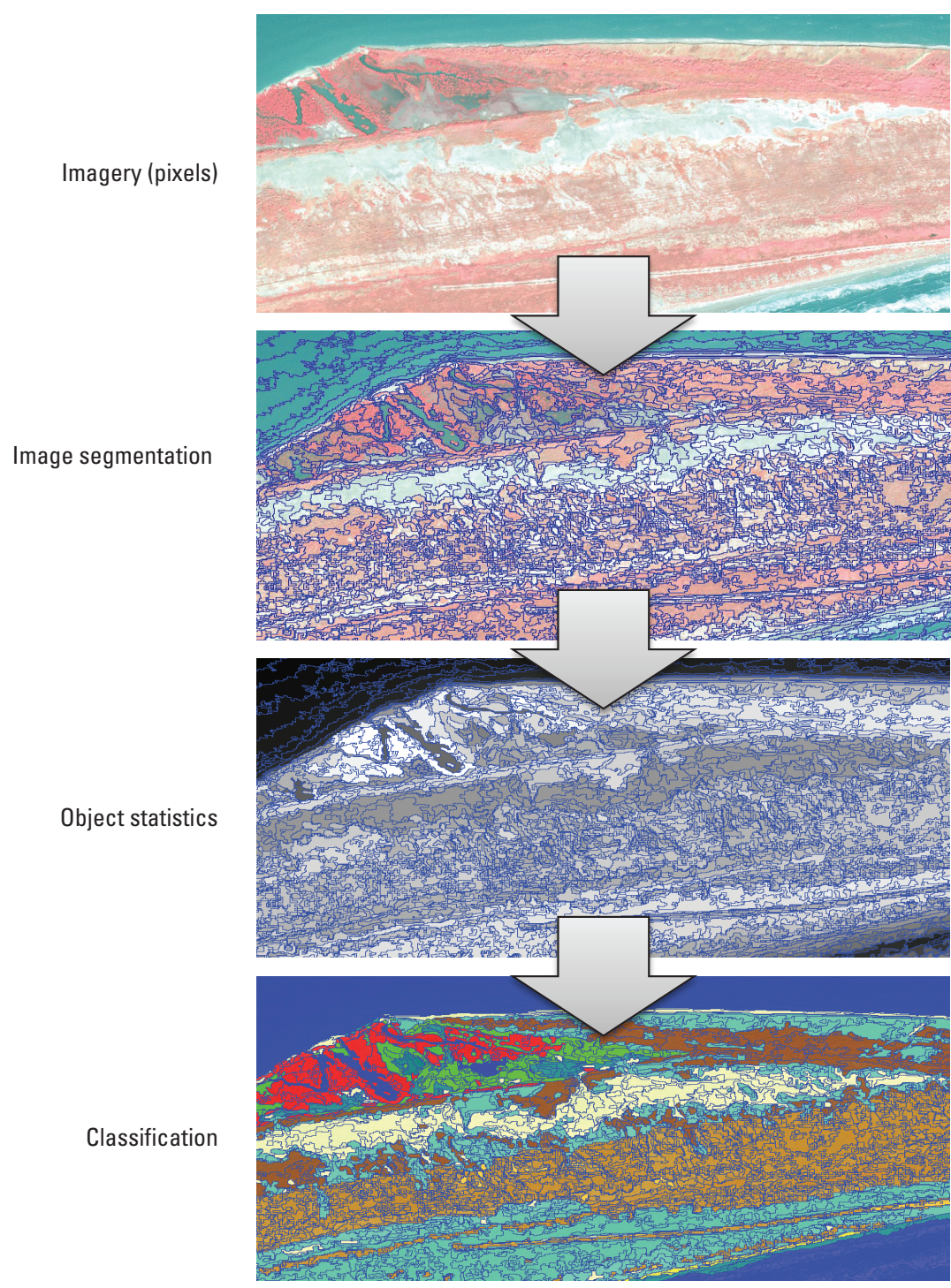

Figure 3. Example of workflow for using geographic object-based image analyses for habitat mapping for the Louisiana Barrier Island Comprehensive Monitoring Program.

\section{Data Post-Processing}

Reach-specific habitat maps were converted from image objects to a 1-m raster to increase efficiency of manual editing. The map was reviewed for errors and manually edited, as needed. ERDAS Imagine 2017 and 2018 (Hexagon Geospatial, Madison, Ala.) were used for manually editing rasters. To generalize the map, we applied a majority filter for a 3-pixel by 3-pixel neighborhood and then applied a 0.01 acre (that is, about 40 square meters $\left[\mathrm{m}^{2}\right]$ ) minimum mapping unit (MMU). Note, the MMU was not applied to the developed class. We selected this MMU as a reasonable balance between noise reduction and loss of detail. This MMU is well below the smallest MMU (that is, 2,500 $\mathrm{m}^{2}$ ) suggested by the USGS and the National Park Service for mapping vegetation in national parks (Lea and Curtis, 2010). The reach-specific raster-based habitat maps were mosaicked into a region-wide habitat map. We converted these region-wide maps to vector data by using the simplify polygon option. The rationale for using the simplify polygon option was to create more aesthetically pleasing habitat maps like other detailed habitat maps, such as the U.S. Fish and Wildlife Service's National Wetlands Inventory. At this point, all attribution was completed, and the product was finalized.

\section{Habitat Classific ation Accuracy Assessment}

We assessed the habitat map accuracy by using photointerpretation of source data following general guidelines by Congalton and Green (2009). For each reach, we attempted to generate 30 random points per class with a minimum distance of $5 \mathrm{~m}$. In some cases, we were not able to obtain the desired number of points per class because of limited areal coverage of habitat. We buffered the random points by $2 \mathrm{~m}$. We identified the habitat class that covered the majority of each buffered area via photointepretation of orthophotography, elevation data, and relative topography. Likewise, we determined the mapped habitat class that covered the majority of each random buffer. These reference data were used to assess the overall accuracy and the user's and producer's accuracies of each class. We excluded the Kappa statistic (Cohen, 1960) based on guidance by Pontius and Millones (2011) and Stehman and Foody (2019). Stehman and Foody (2019) reviewed research regarding the usage of the Kappa statistic for remote sensing accuracy assessments and confirmed prior guidance by Pontius and Millones (2011) that the Kappa statistic should be omitted from 


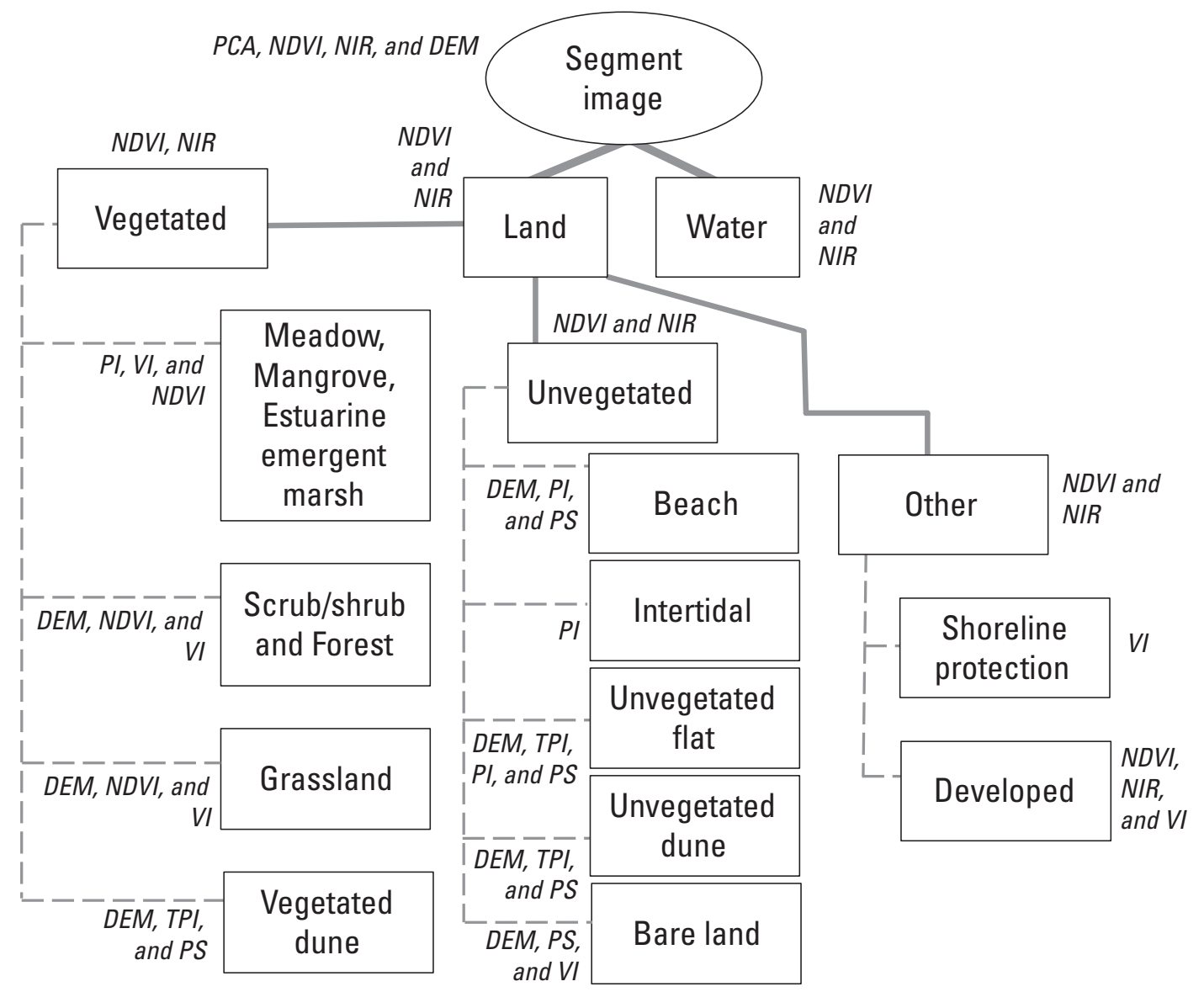

Figure 4. An overview of the mapping process used for the barrier island habitat maps for the Louisiana Barrier Island Comprehensive Monitoring Program for the detailed scheme. The italic text indicates data or techniques used for classifying each habitat. Modified from Enwright and others (2019) with permission. [PCA, principal component analysis; NDVI, normalized difference vegetation index; NIR, near infrared band; DEM, digital elevation model; PI, probability of being intertidal; VI, photointerpretation; PS, probability of being above water levels during extreme storms; TPI, topographic position index. VI was used for all mapping steps and classes.]

accuracy assessments because of several factors, including the high degree of correlation with the overall accuracy statistic (Lu and Weng, 2007). Also, the Kappa statistic rarely changes the interpretation of the map when compared to the overall accuracy (Pontius and Millones, 2011), and a map that is created from a random classification, which is the reference point for the Kappa statistic, is unrealistic (Ye and others, 2018).

\section{Habitat Change and Accuracy Assessment}

The habitat change analyses depict and summarize change between habitat maps from 2008 and 2015-16 per BICM reach. The results from these analyses highlighted changes based on land/water classes and classes related to general inundation frequency (table 5). The land/water change classification scheme bins change into 4 classes, whereas the inundation zone-based (IZB) change classification scheme bins change into 15 different classes (table 6).

Change was determined by intersecting the habitat maps from each date. Similar to the approach used by Zhou and others (2008), we applied two constraints on the changed polygons to reduce noise in the maps and issues associated with image misregistration: (1) the changed polygon must be greater than the MMU, and (2) the changed polygon must have a minimum width of $2 \mathrm{~m}$. In other words, polygons that experienced change (for example, land gain), but had a total area of less than $40 \mathrm{~m}^{2}$ and (or) narrow portions of a polygon that were less than $2 \mathrm{~m}$ were assigned to the appropriate unchanged class (for example, water unchanged). We explored the use of increased width constraints; however, we decided to use $2 \mathrm{~m}$ to be consistent with the work of Zhou and others (2008) and 
Table 5. Louisiana Barrier Island Comprehensive Monitoring (BICM) Program change product bins for the land/water and inundation zone-based habitat change products with associated BICM detailed habitat classes.

\begin{tabular}{|c|c|c|}
\hline $\begin{array}{l}\text { BICM habitat } \\
\text { change product }\end{array}$ & $\begin{array}{l}\text { Generalized classes for } \\
\text { change }\end{array}$ & BICM detailed habitat classes \\
\hline \multirow[t]{2}{*}{ Land/water } & Land & $\begin{array}{l}\text { Bare land, beach, developed, estuarine emergent marsh, forested, grassland, man- } \\
\text { grove, scrub/shrub, shoreline protection, unvegetated dune, unvegetated flat, } \\
\text { vegetated dune }\end{array}$ \\
\hline & Water & Water, intertidal \\
\hline \multirow[t]{4}{*}{ Inundation zone-based } & Water & Water \\
\hline & Intertidal-vegetated & Estuarine emergent marsh, mangrove \\
\hline & Supratidal & $\begin{array}{l}\text { Bare land, beach, forest, grassland, meadow, scrub/shrub, unvegetated dune, } \\
\text { unvegetated flat, vegetated dune }\end{array}$ \\
\hline & $\begin{array}{l}\text { Developed/shoreline protec- } \\
\text { tion }\end{array}$ & Developed, shoreline protection \\
\hline
\end{tabular}

Table 6. Louisiana Barrier Island Comprehensive Monitoring (BICM) Program change classes for the land/water and inundation zone-based habitat change products.

\begin{tabular}{lll}
\hline $\begin{array}{c}\text { BICM habitat } \\
\text { change product }\end{array}$ & \multicolumn{2}{c}{ Habitat change classes } \\
\hline Land/water & $\begin{array}{l}\text { 1. Land gain } \\
\text { 2. Land loss }\end{array}$ & $\begin{array}{l}\text { 3. Land unchanged } \\
\text { 4. Water unchanged }\end{array}$ \\
\hline $\begin{array}{l}\text { Inundation zone- } \\
\text { based }\end{array}$ & 1. Intertidal-vegetated to supratidal/upland & 9. Water to intertidal-unvegetated \\
& 2. Intertidal-unvegetated to supratidal/upland & 10. Supratidal/upland to water \\
& 3. Water to supratidal/upland & 11. Intertidal-vegetated to water \\
& 4. Supratidal/upland to intertidal-vegetated & 12. Intertidal-unvegetated to water \\
& 5. Intertidal-unvegetated to intertidal-vegetated & 13. Developed/shoreline protection gain \\
& 6. Water to intertidal-vegetated & 14. Developed/shoreline protection loss \\
& 7. Supratidal/upland to intertidal-unvegetated & 15. Unchanged \\
\hline
\end{tabular}

because of the $\sim 1$-m root mean square error for image matching the $2015-16$ orthophotography to 2008 orthophotography. The two constraints were applied in a stepwise fashion. First, we applied the MMU and recoded small polygons to the appropriate unchanged class for the land/water change dataset and the unchanged class for the inundation-based zone change dataset. Next, we applied the width constraint and removed areas within changed polygons that were generally less than $2 \mathrm{~m}$ wide. Finally, we reapplied the MMU constraint because the width constraint can reintroduce small change polygons that are below the MMU.

Even with the application of constraints to reduce noise, it is important to assess the accuracy of the change map data. We assessed the change map accuracy by using photointerpretation of source data following general guidelines by Congalton and Green (2009). For each region, we generated 100 random points per class. For this assessment, we placed equal portions of randomly selected points within interior and edge areas (that is, areas within a 4-m interior buffer). A comparison between accuracy results of points sampled from both interior and edge areas, and excluding points from the edge area, respectively, showed that targeting samples in the edge may lead to a lower accuracy result. However, highlighting habitat change along transition areas was important for this effort. Similar to the assessment of habitat maps, we assessed the habitat change class at each point via photointerpretation of orthophotography, elevation data, and relative topography. We did not buffer the habitat change accuracy assessment points. The rationale for this was due to the complexity of determining the majority change for an area, especially for buffered points located along the edge of a polygon.

The accuracy assessment included both deterministic and fuzzy accuracy. We used a fuzzy accuracy assessment approach developed by Woodcock and Gopal (2000), which allowed for the classification of (1) exact match (for example, area is determined to be the same change class in both the 
change map and for reference data); (2) acceptable match because of a high level of subjectivity at the location or different water levels between the two maps used to detect change; or (3) unacceptable/error (for example, mapping an area as land gain when it is water for both dates). Fuzzy accuracy is well suited for assessing barrier island habitats because of dynamic transitions such as water and intertidal classes, which are dependent on water level, or along the transition zones of supratidal and intertidal zones (for example, beach to intertidal or meadow to estuarine emergent marsh); therefore, we present the fuzzy accuracy assessment results in this report. For deterministic accuracy assessment results, see the metadata for regional datasets (Enwright and others, 2018a). The accuracy assessment includes deterministic accuracy and fuzzy accuracy estimates, including overall accuracy and the user's and producer's accuracies for each class. Again, we excluded the Kappa statistic (Cohen, 1960) based on guidance by Pontius and Millones (2011) and Stehman and Foody (2019). Despite the application of these constraints, errors identified in the accuracy assessment of the change data could still be from localized misregistration, fuzzy areas along habitat transitions, and habitat map discrepancies based on subjectivity.

\section{Habitat Reporting Tool}

The BICM Program developed a custom web-enabled mapping and reporting application called the "Habitat Reporting Tool" (HRT). The goal of this tool was to allow the habitat and habitat change datasets to be broadly accessed (that is, visualized) by natural resource managers, researchers, and the general public without the need for specialized technical software packages. The application is an Internet Information Services-hosted C\#.NET application with backend dependencies on Microsoft SQL Server for tabular data and Esri ArcGIS Server 10.7 for spatial geometry, layer symbology, and performance caching. The backend is additionally dependent on PDFSharp (Empire Software, Germany) to develop reachspecific Portable Document Format (PDF) maps. Lastly, the application depends on several client-side libraries, including Bootstrap, jQuery, and the Esri ArcGIS Javascript application programming interface.

\section{Data Analyses}

For the entire BICM study area and each region, we highlighted the top five nonwater detailed habitat classes in terms of areal coverage. We summarized percent change by detailed habitat classes from 2008 to $2015-16$ by region. We did not analyze the percent change for general habitats because these were not explicitly mapped, but instead were developed by using a crosswalk. As previously mentioned, these data were developed for anyone that is interested in comparing 2008 and 2015-16 with historical BICM habitat data (that is, 1997/1998, 2001, 2004, and 2005). We binned the percent decrease and percent increase estimates into quantiles.
We determined the percentage of the total for each of the land/water and IZB habitat change classes, excluding the developed/shoreline protection change classes. To do this, we excluded the land unchanged and water unchanged classes for the land/water change data and the unchanged class for the IZB change data from the total changed estimates. As previously mentioned, we considered general linkages to change in a region with hurricanes, extreme storms, shoreline changes (Byrnes and others, 2018), and restoration efforts that occurred between 2008 and 2015-16. SigmaPlot 14.0 (Systat Software, Inc., San Jose, Calif.) was used to produce plots.

\section{Results and Discussion}

\section{Habitat and Habitat Change Data}

Habitat maps were developed by the BICM Program to show the detailed and general habitat classes for the Whiskey Island reach (fig. 5). Maps of the Whiskey Island reach showing the land/water and IZB habitat changes are shown in figures 6 and 7, respectively. All the habitat datasets and habitat change datasets have been published in a USGS data release (Enwright and others, 2018a). These data include recommended symbology files and Federal Geographic Data Committee-compliant metadata. These data are also available on the BICM project page on the CIMS (https://cims.coastal.louisiana.gov/outreach/projects/bicm).

Data produced through this effort are available in the BICM HRT (https://warcapps.usgs.gov/bicm). As previously mentioned, the HRT allows users to visualize the BICM habitat and habitat change datasets and develop standardized reach-specific maps as PDF files without the need of a geographic information system software package (fig. 8). The HRT includes a wizard that guides the user through a series of questions to develop either a single- or multi-pane web map. The resulting map includes a user-specified combination of BICM habitat maps and habitat change maps developed by the USGS. Users can also use the tool to create reach-specific habitat maps and habitat change maps as downloadable PDF files.

\section{Habitat and Habitat Change Accuracy}

Detailed accuracy assessment results are listed in table 7. The overall accuracy for the detailed habitat maps from 2008 for the seven BICM regions ranged from 89.2 to 96.7 percent $($ mean $=93.4$ percent, $\mathrm{SD}=2.6$ percent). The overall accuracy for the detailed habitat maps from 2015-16 for the seven BICM regions ranged from 94.6 to 97.4 percent (mean $=95.9$ percent, $\mathrm{SD}=0.9$ percent). For all habitat maps, the lowest producer's accuracy (that is, omission error) was for unvegetated dune with a mean of 89.2 percent and an SD of 11.2 percent, whereas estuarine emergent marsh had the lowest user's accuracy (that is, commission error) with a mean of 92.6 percent and an SD of 4.9 percent. The higher accuracies 


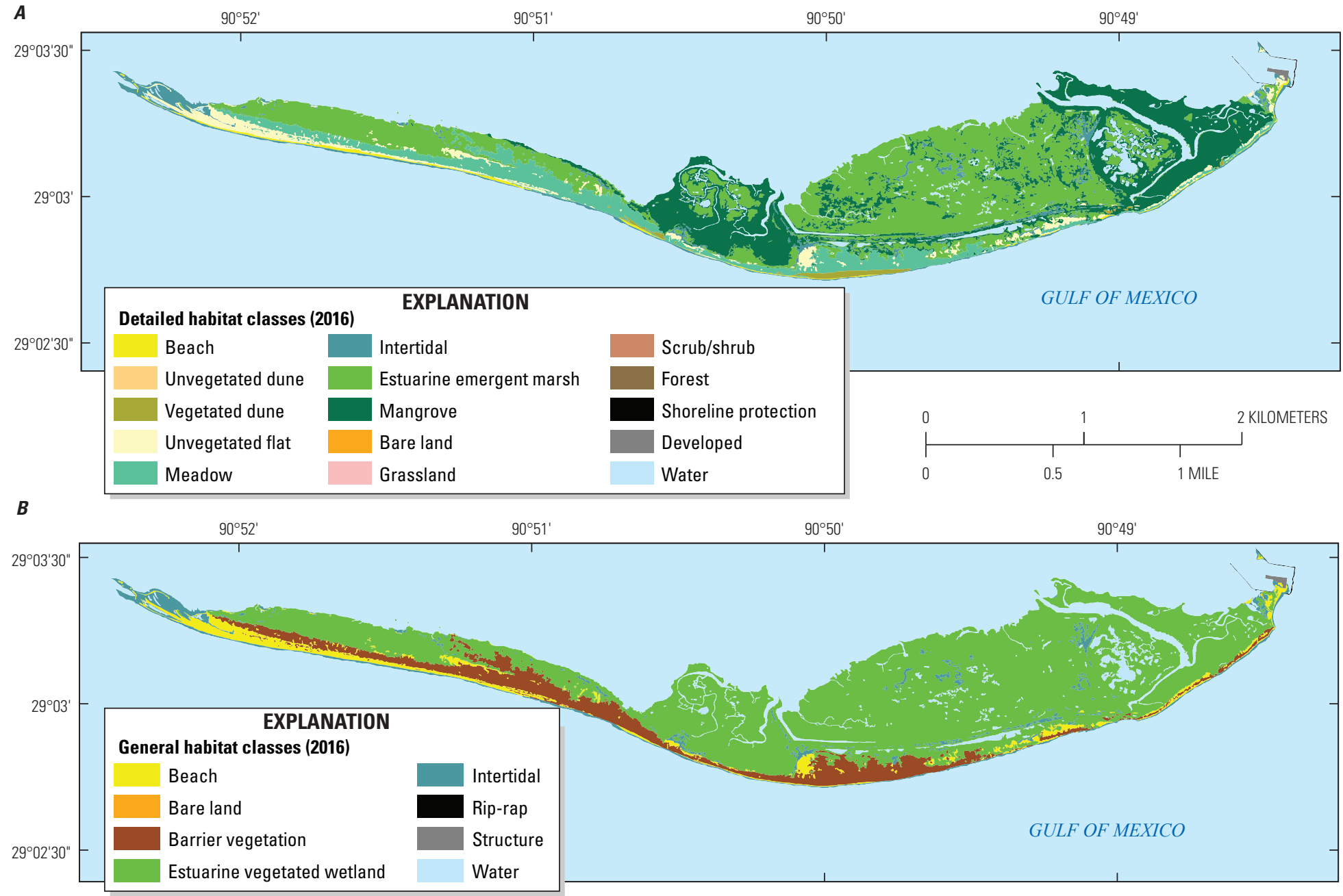

Figure 5. Louisiana Barrier Island Comprehensive Monitoring Program $A$, detailed habitat classes and $B$, general habitat classes, 2016, Whiskey Island, Louisiana. 


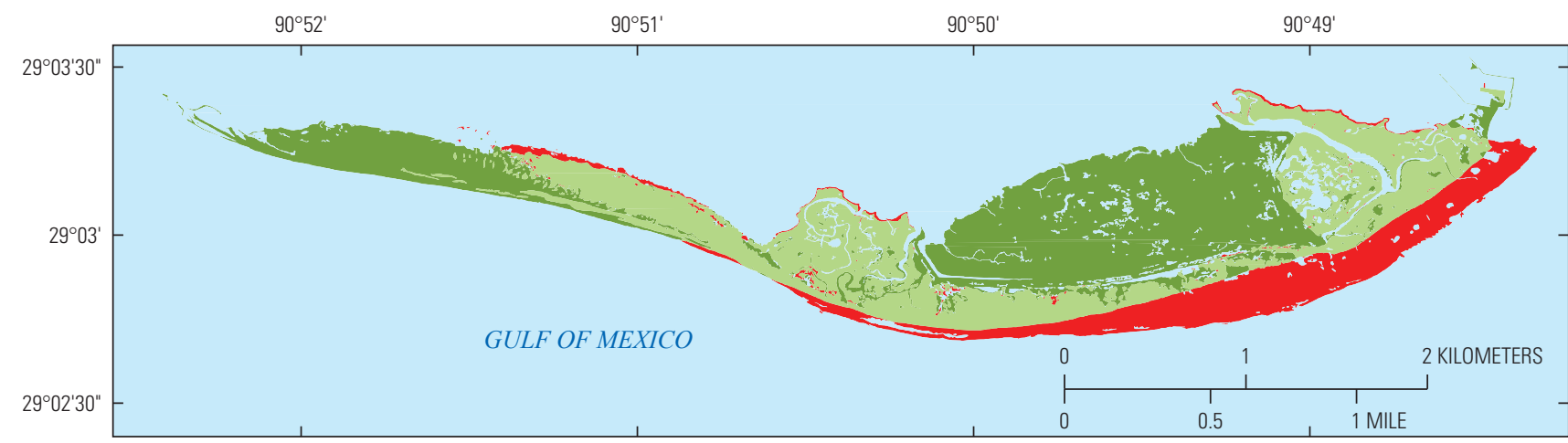

\begin{tabular}{|c|c|}
\hline \multicolumn{2}{|c|}{$\begin{array}{l}\text { EXPLANATION } \\
\text { Land/water-based change classes } \\
(2008-16)\end{array}$} \\
\hline Land gain & Land unchanged \\
\hline Land loss & Water unchanged \\
\hline
\end{tabular}

Figure 6. Louisiana Barrier Island Comprehensive Monitoring Program land/water-based change classes for 2008-16 for Whiskey Island, Louisiana.

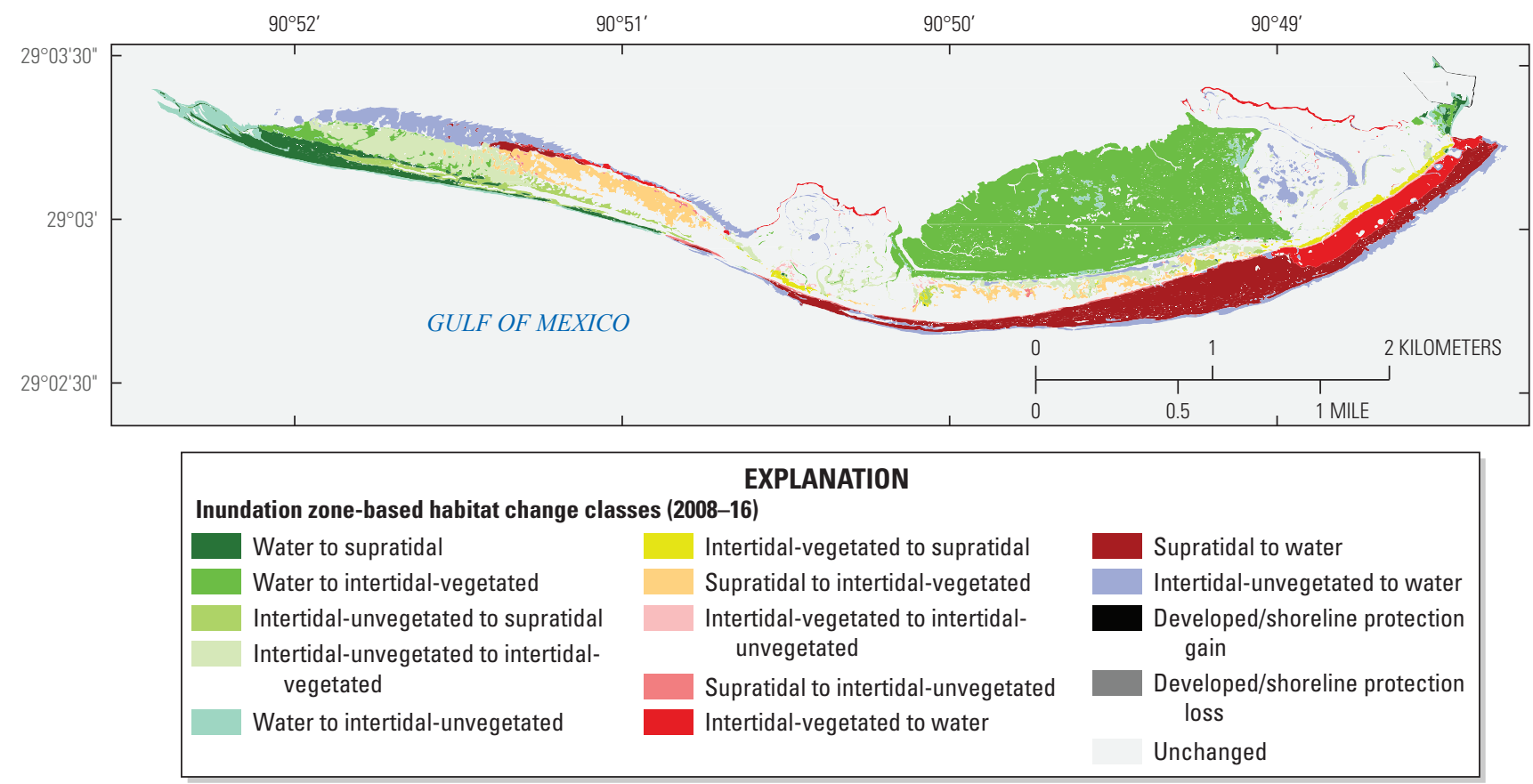

Figure 7. Louisiana Barrier Island Comprehensive Monitoring Program inundation zone-based habitat change classes for 2008-16 for Whiskey Island, Louisiana.

associated with these habitat data (that is, often greater than 90 percent) were likely caused by the use of a semiautomated process that included manual editing of the products, which took a substantial amount of time.

The fuzzy accuracy assessment results for the land/water change datasets are listed in table 8 . The fuzzy overall accuracy for these data for the seven BICM regions ranged from 93.0 to 99.5 percent (mean $=96.6$ percent, $\mathrm{SD}=2.0$ percent).
The lowest fuzzy producer's accuracy was for land unchanged with a mean of 94.7 percent and an SD of 4.0 percent, whereas land gain had the lowest fuzzy user's accuracy with a mean of 94.3 percent and an SD of 5.6 percent.

The fuzzy accuracy assessment results for the IZB change datasets are listed in table 9. The fuzzy overall accuracy for these data for the seven BICM regions ranged from 87.0 to 99.2 percent $($ mean $=92.1$ percent, $\mathrm{SD}=4.3$ percent $)$. 

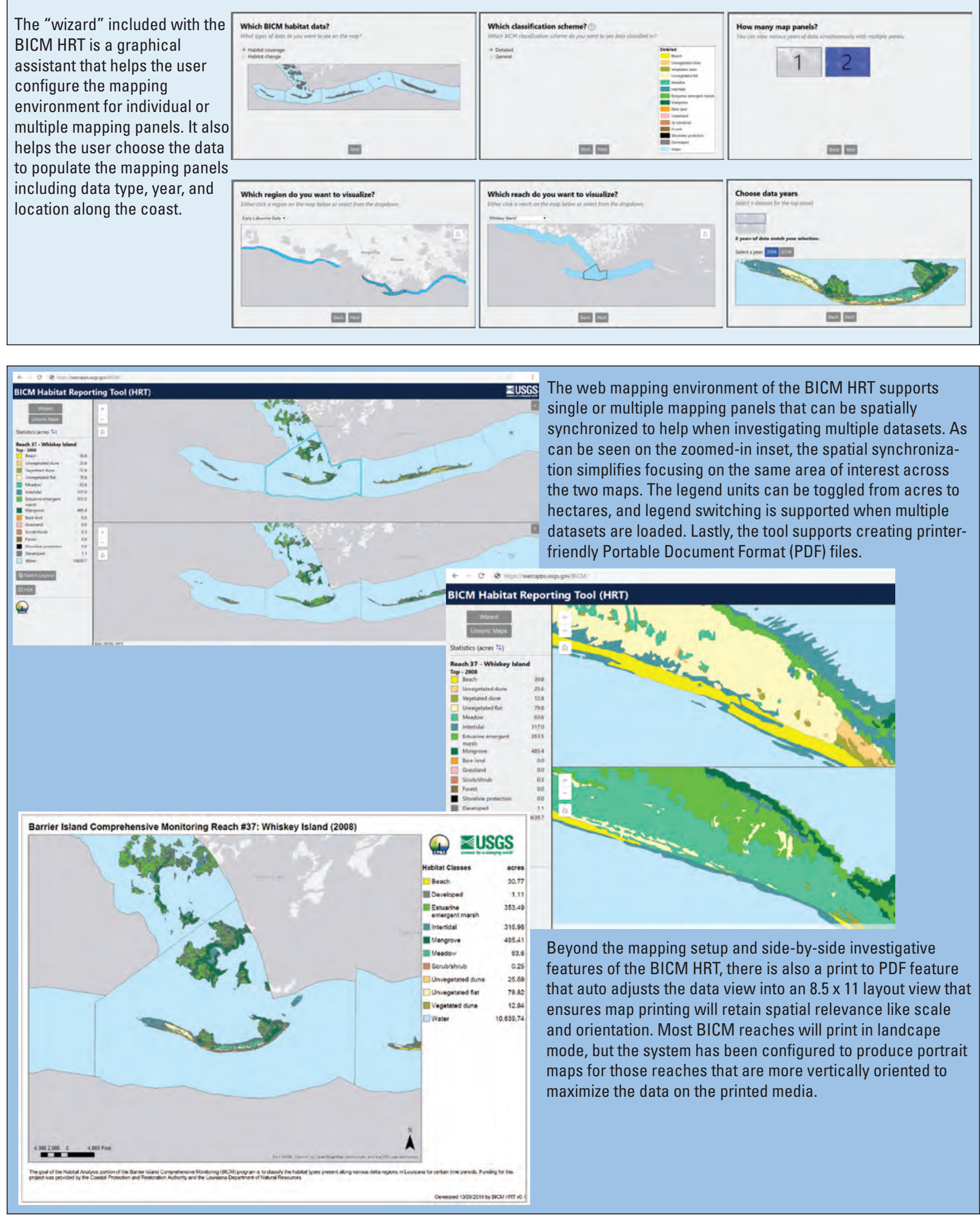

Figure 8. Overview of the functionality of the Louisiana Barrier Island Comprehensive Monitoring (BICM) Program Habitat Reporting Tool (HRT). 
Table 7. Accuracy assessment results for detailed habitat classes for 2008 and 2015-16, by Louisiana Barrier Island Comprehensive Monitoring Program region.

[OA, overall accuracy; \%, percent; BL, bare land; B, beach; DV, developed; EM, estuarine emergent marsh; F, forest; GL, grassland; I, intertidal; MG, mangrove; MW, meadow; SS, scrub/shrub; SP, shoreline protection; UD, unvegetated dune; UF, unvegetated flat; VD, vegetated dune; W, water; WC, West Chenier Plain; --, not applicable; EC, East Chenier Plain; AB, Acadiana Bays; ELD, Early Lafourche Delta; LLD; Late Lafourche Delta; MD, Modern Delta; CI, Chandeleur Islands]

\begin{tabular}{|c|c|c|c|c|c|c|c|c|c|c|c|c|c|c|c|c|c|}
\hline \multirow{2}{*}{$\begin{array}{l}\text { Region } \\
\text { (fig. 1) }\end{array}$} & \multirow[t]{2}{*}{ Map date } & \multirow[t]{2}{*}{$\mathbf{O A}(\%)$} & \multicolumn{15}{|c|}{$\begin{array}{c}\text { Class-specific accuracy } \\
\text { (Per map date: first row, producer's accuracy [\%] and second row, user's accuracy [\%]) }\end{array}$} \\
\hline & & & BL & B & DV & EM & $\mathbf{F}$ & $\mathbf{G L}$ & $I$ & MG & MW & SS & SP & UD & UF & VD & $\mathbf{W}$ \\
\hline \multirow[t]{4}{*}{ WC } & 2008 & 89.2 & 68.5 & 88.7 & 97.7 & 94.2 & 91.2 & 71.1 & 95.0 & -- & 73.1 & 89.2 & 93.7 & 87.9 & 95.4 & 87.8 & 99.1 \\
\hline & & & 96.1 & 96.6 & 97.7 & 82.6 & 83.0 & 90.9 & 87.4 & -- & 75.4 & 89.2 & 100.0 & 85.1 & 85.6 & 90.2 & 92.2 \\
\hline & 2015 & 96.2 & 94.1 & 96.0 & 98.7 & 100.0 & 94.9 & 95.4 & 98.0 & -- & 99.3 & 90.1 & 89.3 & 96.5 & 96.0 & 97.4 & 99.3 \\
\hline & & & 100.0 & 99.3 & 98.0 & 91.0 & 94.9 & 93.6 & 96.7 & -- & 93.7 & 98.3 & 100.0 & 97.2 & 96.7 & 97.4 & 93.1 \\
\hline \multirow[t]{4}{*}{$\mathrm{EC}$} & 2008 & 96.7 & 94.2 & 98.6 & 94.0 & 100.0 & 96.7 & 97.4 & 94.6 & -- & 94.8 & 97.2 & 98.7 & 98.5 & 93.6 & 95.7 & 99.3 \\
\hline & & & 100.0 & 95.9 & 99.0 & 91.8 & 97.8 & 94.8 & 100.0 & -- & 96.7 & 97.2 & 100.0 & 94.8 & 97.8 & 100.0 & 96.1 \\
\hline & 2015 & 95.8 & 100.0 & 90.8 & 94.9 & 98.4 & 96.6 & 96.6 & 97.2 & -- & 95.2 & 96.8 & -- & 94.1 & 95.9 & 96.8 & 97.5 \\
\hline & & & 100.0 & 99.2 & 98.9 & 92.8 & 98.3 & 100.0 & 91.5 & -- & 96.6 & 96.0 & -- & 99.1 & 91.5 & 95.7 & 92.8 \\
\hline \multirow[t]{4}{*}{$\mathrm{AB}$} & 2008 & 96.1 & 85.7 & 92.9 & 93.3 & 100.0 & -- & 97.2 & 96.8 & -- & 100.0 & 96.2 & -- & 100.0 & 89.7 & 100.0 & 100.0 \\
\hline & & & 96.0 & 100.0 & 100.0 & 93.9 & -- & 97.2 & 93.8 & -- & 96.9 & 86.2 & -- & 100.0 & 100.0 & 100.0 & 90.9 \\
\hline & 2015-16 & 95.4 & 90.3 & 96.7 & 100.0 & 100.0 & 100.0 & 96.6 & 89.7 & -- & 100.0 & 100.0 & -- & 80.0 & 96.7 & 96.7 & 100.0 \\
\hline & & & 96.6 & 96.7 & 100.0 & 100.0 & 100.0 & 96.6 & 89.7 & -- & 100.0 & 100.0 & -- & 96.0 & 93.6 & 87.9 & 90.9 \\
\hline \multirow[t]{4}{*}{ ELD } & 2008 & 92.7 & 96.5 & 95.2 & 95.4 & 93.7 & -- & 100.0 & 91.4 & 90.1 & 91.7 & 90.7 & 88.0 & 85.0 & 93.9 & 85.2 & 100.0 \\
\hline & & & 98.2 & 91.9 & 100.0 & 86.2 & -- & 96.0 & 91.9 & 95.5 & 92.2 & 92.9 & 100.0 & 90.5 & 88.1 & 94.2 & 91.7 \\
\hline & 2016 & 95.4 & 100.0 & 96.0 & 83.9 & 96.7 & -- & 100.0 & 96.6 & 97.2 & 93.1 & 97.7 & 93.8 & 92.2 & 93.4 & 98.1 & 99.5 \\
\hline & & & 100.0 & 99.0 & 100.0 & 96.2 & -- & 98.4 & 97.0 & 95.6 & 93.1 & 99.2 & 100.0 & 92.2 & 93.9 & 96.2 & 86.6 \\
\hline \multirow[t]{4}{*}{ LLD } & 2008 & 94.0 & 96.5 & 94.2 & 99.0 & 96.3 & 96.7 & 94.4 & 94.3 & 91.3 & 88.7 & 95.5 & 98.3 & 89.9 & 90.2 & 91.9 & 99.5 \\
\hline & & & 98.2 & 96.2 & 99.0 & 89.4 & 100.0 & 97.1 & 88.8 & 98.5 & 90.3 & 95.1 & 100.0 & 91.0 & 90.4 & 93.2 & 97.0 \\
\hline & 2016 & 97.4 & 100.0 & 96.9 & 94.8 & 95.1 & 96.8 & 100.0 & 99.1 & 99.0 & 99.6 & 94.9 & 98.8 & 92.9 & 95.7 & 97.2 & 98.6 \\
\hline & & & 97.6 & 97.3 & 98.2 & 99.1 & 96.8 & 94.0 & 96.6 & 99.0 & 97.2 & 96.5 & 95.2 & 97.5 & 99.0 & 96.1 & 94.8 \\
\hline \multirow[t]{4}{*}{ MD } & 2008 & 93.6 & 96.9 & 96.6 & 92.6 & 95.4 & -- & 91.3 & 94.9 & 94.1 & 91.5 & 80.6 & 91.8 & 89.4 & 97.0 & 91.1 & 98.4 \\
\hline & & & 100.0 & 98.3 & 98.0 & 92.0 & -- & 84.0 & 93.3 & 89.8 & 91.5 & 96.7 & 100.0 & 97.7 & 87.7 & 98.1 & 91.0 \\
\hline & 2015 & 96.2 & 98.3 & 98.3 & 96.6 & 100.0 & -- & 88.9 & 100.0 & 100.0 & 100.0 & 98.3 & 93.3 & 96.4 & 100.0 & 98.4 & 100.0 \\
\hline & & & 100.0 & 100.0 & 100.0 & 97.4 & -- & 100.0 & 95.3 & 100.0 & 98.5 & 98.3 & 100.0 & 98.2 & 98.4 & 100.0 & 95.5 \\
\hline \multirow[t]{4}{*}{ CI } & 2008 & 91.4 & 100.0 & 92.1 & 66.7 & 83.0 & -- & -- & 93.7 & -- & 84.7 & 93.3 & 90.9 & -- & 95.0 & 88.1 & 99.2 \\
\hline & & & 81.8 & 95.1 & 100.0 & 89.3 & -- & -- & 89.3 & -- & 95.3 & 82.4 & 100.0 & -- & 94.0 & 97.4 & 94.6 \\
\hline & 2016 & 94.6 & -- & 94.5 & 100.0 & 97.8 & -- & -- & 98.9 & 93.4 & 93.4 & 97.1 & 83.3 & 56.8 & 97.8 & 97.4 & 98.9 \\
\hline & & & -- & 98.9 & 100.0 & 95.7 & -- & -- & 96.8 & -- & 96.6 & 100.0 & 83.3 & 95.5 & 88.1 & 73.1 & 98.9 \\
\hline
\end{tabular}


Table 8. Fuzzy accuracy assessment results for land/water change from 2008 to 2015-16, by Louisiana Barrier Island Comprehensive Monitoring Program region.

[OA, overall accuracy; \%, percent; PA, producer's accuracy; UA, user's accuracy; LG, land gain; LL, land loss; LU, land unchanged; WU, water unchanged; WC, West Chenier Plain; EC, East Chenier Plain; AB, Acadiana Bays; ELD, Early Lafourche Delta; LLD, Late Lafourche Delta; MD, Modern Delta; CI, Chandeleur Islands]

\begin{tabular}{|c|c|c|c|c|c|}
\hline \multirow{2}{*}{$\begin{array}{l}\text { Region } \\
\text { (fig. 1) }\end{array}$} & \multirow{2}{*}{$\mathrm{OA}(\%)$} & \multicolumn{4}{|c|}{$\begin{array}{c}\text { Class-specific accuracy } \\
\text { (Per map date: first row, PA [\%] and second row, UA [\%]) }\end{array}$} \\
\hline & & LG & LL & LU & WU \\
\hline \multirow[t]{2}{*}{ WC } & 96.5 & 100.0 & 100.0 & 100.0 & 100.0 \\
\hline & & 100.0 & 100.0 & 100.0 & 100.0 \\
\hline \multirow[t]{2}{*}{$\mathrm{EC}$} & 97.8 & 100.0 & 99.0 & 92.8 & 100.0 \\
\hline & & 94.0 & 99.0 & 100.0 & 98.0 \\
\hline \multirow[t]{2}{*}{$\mathrm{AB}$} & 97.5 & 100.0 & 100.0 & 96.6 & 94.9 \\
\hline & & 92.0 & 98.0 & 100.0 & 100.0 \\
\hline \multirow[t]{2}{*}{ ELD } & 93.0 & 100.0 & 97.0 & 90.0 & 89.0 \\
\hline & & 84.0 & 91.0 & 98.1 & 99.0 \\
\hline \multirow[t]{2}{*}{ LLD } & 95.5 & 100.0 & 100.0 & 90.4 & 93.9 \\
\hline & & 93.0 & 90.0 & 99.0 & 100.0 \\
\hline \multirow[t]{2}{*}{ MD } & 96.5 & 98.0 & 100.0 & 94.1 & 94.6 \\
\hline & & 97.0 & 92.0 & 98.0 & 99.0 \\
\hline \multirow[t]{2}{*}{ CI } & 99.5 & 100.0 & 100.0 & 99.0 & 98.0 \\
\hline & & 100.0 & 98.0 & 100.0 & 100.0 \\
\hline
\end{tabular}

While the fuzzy overall accuracy is still high, some classspecific accuracy assessments were low. The two lowest fuzzy producer's accuracies were for unchanged with a mean of 65.0 percent and an SD of 17.5 percent and intertidalvegetated to supratidal/upland with a mean of 76.8 percent and an SD of 21.8 percent. The two fuzzy lowest user's accuracies were for intertidal-vegetated to supratidal/upland with a mean of 56.7 percent and an SD of 26.2 percent and developed/ shoreline protection gain with a mean of 82.4 percent and an $\mathrm{SD}$ of 22.5 percent. As previously mentioned, the accuracy assessment targeted edges and interior areas equally. The rationale for this was that edges (that is, transition areas between habitats) could be areas where errors were concentrated. Yet, for the habitat change classes, the edges of polygons (that is, transition areas) can be difficult to assess because a point could be ambiguous and not clearly in a specific class. Thus, we also presented the accuracy assessment results for all points (that is, interior and exterior) as well as the accuracy assessment results for the interior points in the metadata for the regional change datasets (Enwright and others, 2018a). While image matching and constraints were used to reduce issues with image registration differences between the dates, it is still possible to have issues with false change from registration in areas where the registration error is especially high. One downside of a semiautomated approach is that methods, such as photointerpretation, introduce subjectivity into the mapping process, which can lead to change error. One example of this type of error could be inconsistent mapping of small ponds within estuarine emergent marsh between both dates. These results highlight the importance of ensuring that the mapping process takes advantage of as much automation as possible to enhance the consistency of the results.

\section{BICM Region-Wide Habitat and Habitat Change}

The focus of this section is the habitat and habitat change results across the entire BICM region. Regional results will be discussed in subsequent sections of this report. The areal coverages for detailed and general habitat maps by reach are reported in the appendix (table 1-1; table 1-2). The five nonwater detailed habitat classes in 2008 with the highest areal coverages were (1) estuarine emergent marsh $(54,803.30$ hectares [ha]; 26.7 percent of total area [that is, including water]); (2) intertidal (4,391.48 ha; 2.1 percent); (3) grassland (2,368.55 ha; 1.2 percent); (4) meadow (1,628.61 ha; 0.8 percent); and (5) unvegetated flat (1,279.99 ha; 0.6 percent) (table $1-1$; fig. 9). The five nonwater detailed habitat classes with the highest areal coverage in 2015-16 were (1) estuarine emergent marsh $(54,238.80$ ha; 26.4 percent); (2) meadow (2,319.98 ha; 1.1 percent); (3) mangrove (1,937.03 ha; 0.9 percent); (4) grassland (1,880.14 ha; 0.9 percent); and (5) scrub/shrub (1,801.88 ha; 0.9 percent) (table $1-1$; fig. 9).

Table 10 lists the percent change between 2008 and 2015-16 per class by region. Habitats that increased throughout the entire BICM region were vegetated dune, scrub/shrub, 
Table 9. Fuzzy accuracy assessment results for inundation zone-based habitat change classes for change from 2008 to 2015-16, by Louisiana Barrier Island Comprehensive Monitoring Program region.

[OA, overall accuracy; \%, percent; S-IV, supratidal/upland to intertidal-vegetated; S-IUV, supratidal/upland to intertidal-unvegetated; S-W supratidal/upland to water; IV-S, intertidal-vegetated to supratidal/ upland; IV-IUV, intertidal-vegetated to intertidal-unvegetated; IV-W, intertidal-vegetated to water; IUV-S, intertidal-unvegetated to supratidal/upland; IUV-IV, intertidal-unvegetated to intertidal-vegetated;

IUV-W, intertidal-unvegetated to water; W-S, water to supratidal/upland; W-IV, water to intertidal-vegetated; W-IUV, water to intertidal-unvegetated; DSPG, developed/shoreline protection gain; DSPL, developed/shoreline protection loss; U, unchanged; WC, West Chenier Plain; EC, East Chenier Plain; AB, Acadiana Bays; ELD, Early Lafourche Delta; LLD, Late Lafourche Delta; MD, Modern Delta; CI, Chandeleur Islands]

\begin{tabular}{|c|c|c|c|c|c|c|c|c|c|c|c|c|c|c|c|c|}
\hline \multirow{2}{*}{$\begin{array}{l}\text { Region } \\
\text { (fig. 1) }\end{array}$} & \multirow[t]{2}{*}{$\mathrm{OA}(\%)$} & \multicolumn{15}{|c|}{$\begin{array}{c}\text { Class-specific accuracy } \\
\text { (Per map date: first row, producer's accuracy [\%] and second row, user's accuracy [\%]) }\end{array}$} \\
\hline & & S-IV & S-IUV & S-W & IV-S & IV-IUV & IV-W & IUV-S & IUV-IV & IUV-W & W-S & W-IV & W-IUV & DSPG & DSPL & $\mathbf{U}$ \\
\hline \multirow[t]{2}{*}{ WC } & 87.0 & 100.0 & 100.0 & 100.0 & 100.0 & 98.0 & 100.0 & 98.0 & 99.0 & 100.0 & 100.0 & 97.9 & 99.0 & 100.0 & 100.0 & 48.8 \\
\hline & & 23.0 & 95.0 & 96.0 & 44.0 & 100.0 & 98.0 & 98.0 & 97.0 & 99.0 & 98.0 & 99.0 & 97.0 & 83.0 & 78.0 & 100.0 \\
\hline \multirow[t]{2}{*}{$\mathrm{EC}$} & 93.5 & 100.0 & 100.0 & 100.0 & 100.0 & 98.0 & 100.0 & 100.0 & 77.1 & 99.0 & 100.0 & 100.0 & 100.0 & 100.0 & 100.0 & 68.4 \\
\hline & & 34.0 & 99.0 & 100.0 & 87.0 & 100.0 & 98.0 & 98.0 & 100.0 & 100.0 & 97.0 & 98.0 & 100.0 & 100.0 & 93.4 & 100.0 \\
\hline \multirow[t]{2}{*}{$\mathrm{AB}$} & 95.1 & 100.0 & 98.1 & 100.0 & 97.3 & 98.0 & 100.0 & 100.0 & 97.9 & 100.0 & 100.0 & 100.0 & 100.0 & 100.0 & -- & 76.0 \\
\hline & & 66.0 & 100.0 & 100.0 & 96.0 & 100.0 & 96.0 & 100.0 & 96.0 & 100.0 & 100.0 & 100.0 & 100.0 & 100.0 & -- & 100.0 \\
\hline \multirow[t]{2}{*}{ ELD } & 89.0 & 100.0 & 100.0 & 96.4 & 98.6 & 100.0 & 97.9 & 98.2 & 98.8 & 95.5 & 100.0 & 100.0 & 100.0 & 92.9 & 100.0 & 46.0 \\
\hline & & 68.0 & 97.2 & 99.1 & 83.7 & 95.0 & 96.0 & 97.2 & 88.7 & 98.0 & 100.0 & 86.7 & 100.0 & 38.1 & 77.5 & 95.3 \\
\hline \multirow[t]{2}{*}{ LLD } & 88.1 & 100.0 & 100.0 & 99.0 & 90.5 & 98.7 & 100.0 & 97.9 & 90.6 & 97.2 & 99.0 & 96.2 & 100.0 & 98.7 & 100.0 & 52.2 \\
\hline & & 40.0 & 96.0 & 98.0 & 50.0 & 86.0 & 93.0 & 97.0 & 98.0 & 100.0 & 98.0 & 96.0 & 96.0 & 89.0 & 86.0 & 99.0 \\
\hline \multirow[t]{2}{*}{ MD } & 92.5 & 98.3 & 98.7 & 96.4 & 93.9 & 98.9 & 94.8 & 100.0 & 93.4 & 98.2 & 99.0 & 96.9 & 96.9 & 100.0 & 100.0 & 69.3 \\
\hline & & 66.0 & 88.0 & 96.0 & 77.0 & 97.0 & 95.0 & 95.0 & 98.0 & 98.0 & 100.0 & 98.0 & 99.0 & 97.6 & 86.8 & 97.0 \\
\hline \multirow[t]{2}{*}{ CI } & 99.2 & 99.0 & 100.0 & 100.0 & 100.0 & 100.0 & 100.0 & 100.0 & 99.0 & 100.0 & 100.0 & 99.0 & 100.0 & 100.0 & 100.0 & 94.1 \\
\hline & & 100.0 & 99.0 & 100.0 & 100.0 & 100.0 & 99.0 & 99.0 & 100.0 & 99.0 & 100.0 & 98.0 & 100.0 & 69.2 & 100.0 & 100.0 \\
\hline
\end{tabular}




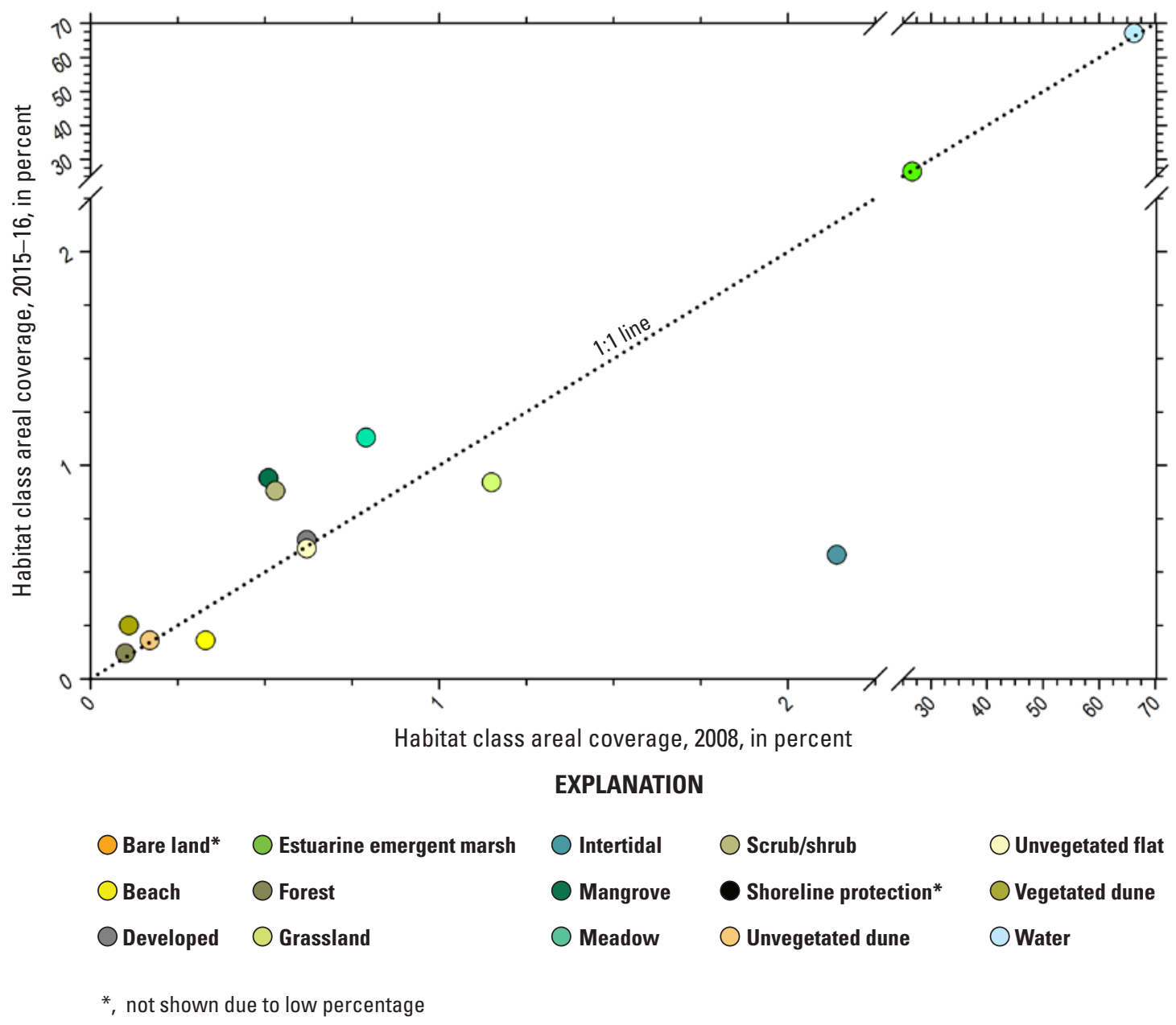

Figure 9. Percentages of habitat class areal coverage in the regions mapped during the Louisiana Barrier Island Comprehensive Monitoring Program habitat analyses (fig. 1), 2008 and 2015-16. Points that are off the 1:1 line represent change in coverage between the time periods.

meadow, and mangrove (table 1-1). Vegetated dune increases were largely attributed to habitat succession on unvegetated dunes. One of the causes for scrub/shrub increase was habitat succession along spoil banks, but also along the backslopes of dunes (that is, meadow habitat). One dynamic aspect of barrier islands, headlands, and coastal shorelines is vegetation burial from overwash during extreme storms and subsequent vegetation recovery (Lucas and Carter, 2013; Brantley and others, 2014). Vegetation burial during extreme storms (that is, Hurricanes Katrina and Rita in 2005 and Hurricanes Gustav and Ike in 2008) and subsequent recovery (that is, habitat succession on unvegetated flats) is one of the main causes for meadow increases. As previously noted, mangrove expansion can occur in the absence of extreme winter temperatures. Recent expansion and contraction of mangroves has occurred in the Barataria Basin (not shown; spans Late Lafourche Delta and Modern Delta regions in fig. 1) (Osland and others, 2017). From 2008 to 2015-16, the intertidal and grassland habitat classes tended to decrease more than the other classes (table 1-1). The change in the intertidal habitat class tended to vary by region; some causes of the changes include water level changes, restoration efforts, and dynamic coastal processes, such as waves and currents, occurring during the time between mapping efforts. Grassland loss can largely be attributed to addition of new spoil along spoil banks (that is, change from grassland to bare land) or habitat succession (that is, change from grassland to scrub/shrub). The other classes either had a mix of increases and decreases by region, or the change was in the lower two quantiles for increase or decrease.

The areal coverage for land/water change and IZB habitat change by reach are reported in tables $1-3$ and $1-4$, respectively. For the entire BICM region, the area experiencing a change in a land/water category (that is, land gain or land loss) was 3.4 percent (table 1-3). Of this change, 59.2 percent of the change was land gain, and 40.8 percent was land loss. For the IZB change (that is, excluding developed/shoreline protection gain or loss), the changed classes accounted for 6.0 percent of the BICM region (table 1-4). The reason for the difference 
[The color indicates the quantile of percent increase or percent decrease, respectively. PDQ1, percent decrease quantile 1; PDQ2, percent decrease quantile 2; PDQ3, percent decrease quantile 3; PDQ4, percent decrease quantile 4; PIQ1, percent increase quantile 1; PIQ2, percent increase quantile 2, PIQ3, percent increase quantile 3; PIQ4, percent increase quantile 4; \%, percent; BL, bare land; B, beach; DV, developed; EM, estuarine emergent marsh; F, forest; GL, grassland; I, intertidal; MG, mangrove; MW, meadow; SS, scrub/shrub; SP, shoreline protection; UD, unvegetated dune; UF, unvegetated flat; VD, vegetated dune; W, water; WC, West Chenier Plain; EC, East Chenier Plain; AB, Acadiana Bays; ELD, Early Lafourche Delta; LLD, Late Lafourche Delta; MD, Modern Delta; CI, Chandeleur Islands]

\begin{tabular}{|c|c|c|c|c|c|c|c|c|c|c|c|c|c|c|c|}
\hline \multicolumn{16}{|c|}{ EXPLANATION } \\
\hline PD01 & PD02 & PD03 & PD04 & PI01 & PI02 & $\mathrm{PIO3}$ & PIC & & & & & & & & \\
\hline \multirow{2}{*}{$\begin{array}{l}\text { Region } \\
\text { (fig. 1) }\end{array}$} & \multicolumn{15}{|c|}{ Percent change (\%; rounded to nearest integer) } \\
\hline & BL & B & DV & EM & $\mathbf{F}$ & GL & $\mathbf{I}$ & MG & MW & SS & SP & UD & UF & VD & $\mathbf{W}$ \\
\hline $\mathrm{WC}$ & -74 & -60 & 10 & 5 & -18 & -12 & -61 & 0 & 45 & 48 & -24 & -49 & -33 & 151 & -5 \\
\hline EC & 67 & -77 & -11 & 0 & 47 & -52 & -47 & 0 & -18 & 110 & 83 & -9 & -39 & 108 & 1 \\
\hline $\mathrm{AB}$ & 853 & 21 & 67 & -4 & 0 & -71 & -85 & 0 & 18 & 94 & 0 & -80 & -5 & 4 & 8 \\
\hline ELD & -31 & -74 & -23 & -5 & 0 & -54 & -93 & 99 & 139 & 43 & -10 & -97 & -66 & 133 & 6 \\
\hline LLD & -59 & -37 & 2 & -23 & 54 & -40 & -78 & 80 & 62 & 49 & -13 & 169 & -19 & 38 & 2 \\
\hline MD & 32 & 68 & -9 & -12 & 0 & 474 & -88 & 78 & 565 & 31 & -30 & 1,008 & 124 & 661 & 1 \\
\hline CI & -100 & 331 & 74 & 88 & 0 & 0 & -22 & 74 & 209 & 4,420 & -43 & -41 & 134 & 58 & -1 \\
\hline
\end{tabular}


between the two change assessments is that intertidal is lumped in with water for the land/water change classification scheme, but not within the IZB change classification scheme (table 5). The IZB change classes with a "high" coverage (that is, greater than $\sim 10.0$ percent) were (1) intertidal-unvegetated to water (21.9 percent); (2) water to intertidal-vegetated (15.2 percent); (3) intertidal-vegetated to water (15.2 percent); and (4) intertidal-vegetated to supratidal/upland (9.9 percent). The high amount of intertidal-unvegetated to water change was likely caused by water levels and dynamic coastal processes. Water and intertidal-vegetated areas had a high degree of transfer between classes (that is, areas swapped values), which was likely caused by restoration efforts that include marsh planting and (or) natural habitat succession on intertidal areas, such as the berm restoration on Chandeluer Island (table 2; FitzGerald and others, 2015), and marsh loss (Couvillion and others, 2017). Intertidal-vegetated to supratidal/upland change could have been caused by restoration efforts or overwash events that increased the elevation of intertidal areas (Walters and Kirwan, 2016).

\section{West Chenier Plain Region Habitat and Habitat Change}

For the West Chenier Plain region, the five nonwater detailed habitat classes with the highest areal coverages in 2008 were (1) estuarine emergent marsh $(13,533.61$ ha; 52.8 percent); (2) grassland ( $1,858.67$ ha; 7.3 percent); (3) intertidal (608.62 ha; 2.4 percent); (4) developed (552.41 ha; 2.2 percent); and (5) scrub/shrub (508.15 ha; 2.0 percent) (table 1-1; fig. 10). The five nonwater detailed habitat classes with the highest areal coverages in 2015 were (1) estuarine emergent marsh (14,183.90 ha; 55.4 percent); (2) grassland (1,626.44 ha; 6.4 percent); (3) scrub/shrub

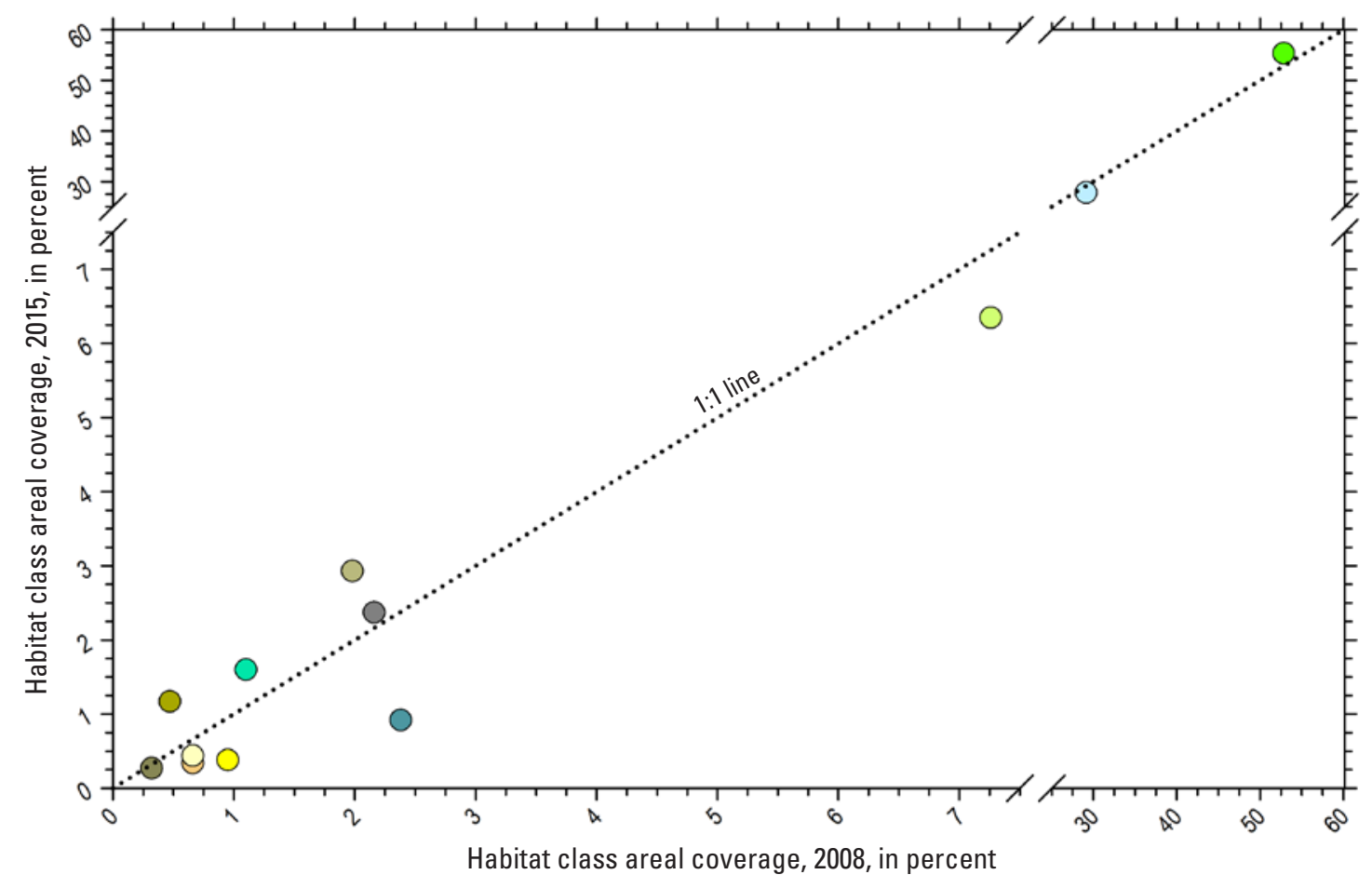

EXPLANATION

\begin{tabular}{|c|c|c|c|c|}
\hline Bare land* & Estuarine emergent marsh & Intertidal & Scrub/shrub & Unvegetated flat \\
\hline Beach & Forest & Mangrove* & Shoreline protection* & Vegetated dune \\
\hline Developed & Grassland & Meadow & Unvegetated dune & Water \\
\hline
\end{tabular}

Figure 10. Percentages of habitat class areal coverage in the West Chenier Plain region mapped during the Louisiana Barrier Island Comprehensive Monitoring Program, 2008 and 2015. Points that are off the 1:1 line represent change in coverage between the time periods. 
(750.82 ha; 2.9 percent); (4) developed (608.12 ha; 2.4 percent); and (5) meadow (409.77 ha; 1.6 percent) ( ; fig. 10). Vegetated dune had a "high" percent increase (that is, either quantile 3 or 4 for percent increase) between these two dates (table 10), mainly because of habitat succession associated with the Cameron Parish Shoreline Restoration project (table 2). Bare land, beach, intertidal, and unvegetated dune classes had "high" percent decreases (table 10; that is, either quantile 3 or 4 for percent decrease). As previously discussed, bare land includes areas with spoil banks, inland ridges, or upland bare areas (table 3 ). In some cases, these bare areas could be in an early phase of development (for example, land clearing phase) or become vegetated over time (for example, spoil banks). The decrease in beach was due to a wider beach zone in 2008 compared to 2015. Some of the decrease in beach could be attributed to the shoreline restoration effort in 2014, which converted some of this area to dune, and (or) insufficient time for shoreface adjustment to occur after sediment placement. Collectively, this creates an elevation high enough to reduce exposure to high energy waves and to become transitional areas in front of a dune (that is, unvegetated flat or meadow; table 3). Additionally, this localized beach loss is also the result of coastal processes and coastal erosion. BICM shoreline analyses by Byrnes and others (2018) found that the West Chenier region had the lowest shoreline loss rate from 2004 to 2012; however, the analyses did point to spatial variability with high amounts of accretion in the Johnsons Bayou (fig. 11), Holly Beach, and Mermentau River reaches. Decrease of intertidal area for this region was largely due to changes in water levels, which reduced the ability to detect intertidal flats in 2015 compared to 2008 in the Johnsons Bayou and Mermentau River reaches. In the accreting western portion of the Johnsons Bayou reach (Byrnes and others, 2018), a large amount of intertidal area became estuarine emergent marsh (fig. 11). Finally, some of the unvegetated dune decrease can be attributed to vegetation succession on the dune associated with the Cameron Parish Shoreline Restoration project.

The area experiencing a change in a land/water category for this region was 4.7 percent (table 1-3). Of this change, 78.8 percent was land gain, and 21.2 percent was land loss (fig. 12). This amount of change is supported by the very low rate of shoreline erosion (that is, -0.7 meter per year $[\mathrm{m} /$ yr]) for this reach from 2004 to 2012, relative to other BICM reaches (Byrnes and others, 2018). For the IZB change (that is, excluding developed/shoreline protection gain or loss), the changed classes accounted for 8.3 percent of the region (table 1-4). These IZB change classes had a "high" coverage: (1) water to intertidal-vegetated (30.3 percent); (2) Supratidal/ upland to intertidal-vegetated (14.5 percent); (3) intertidalunvegetated to water (13.7 percent); and (4) intertidalvegetated to supratidal/upland (13.0 percent) (fig. 13). Water to intertidal-vegetated change was largely due to expansion of emergent marsh at the expense of marsh ponds in the western half of the region and shoreline accretion in the western portion of the Johnsons Bayou reach, which was likely driven by recovery after Hurricanes Gustav and Ike (table 1). The change from supratidal/upland to intertidal-vegetated could be from degradation of spoil banks or changes in shrub/scrub cover (that is, scrub/shrub is considered supratidal/upland and does not account for estuarine scrub/shrub wetlands). However, some changes could be caused by the higher quality lidar data for the 2015 mapping effort (that is, a recent 2017 1-m lidar-based DEM collection; table 4). The changes from intertidal-unvegetated to water for this region were previously discussed. The change from intertidal-vegetated to supratidal/ upland could be a result of the Cameron Parish Shoreline Restoration project increasing elevations in localized areas or overwash increasing the elevation of these areas; however, lidar quality differences between the dates may also be a factor. 

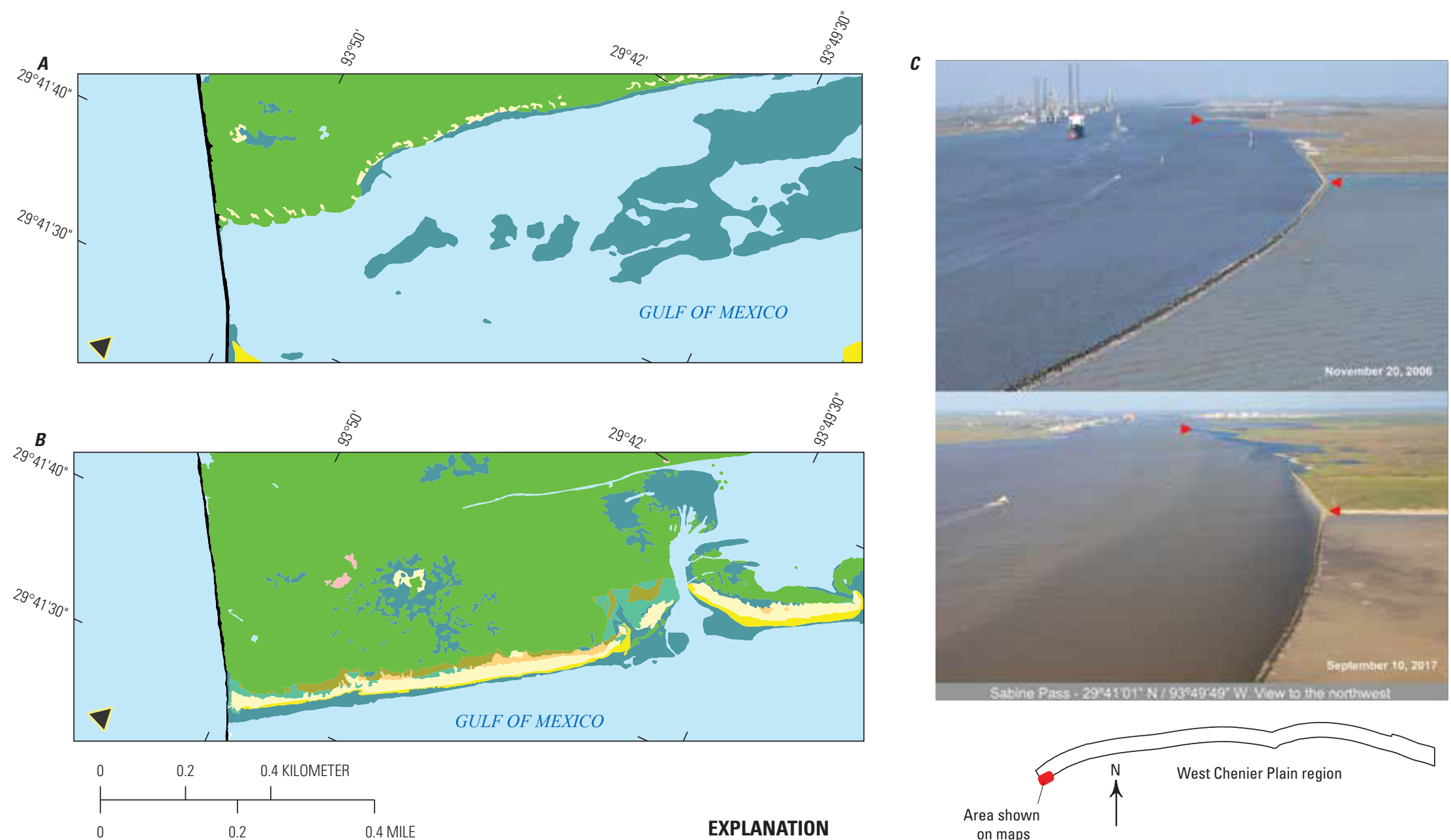

EXPLANATION

Detailed habitat classes

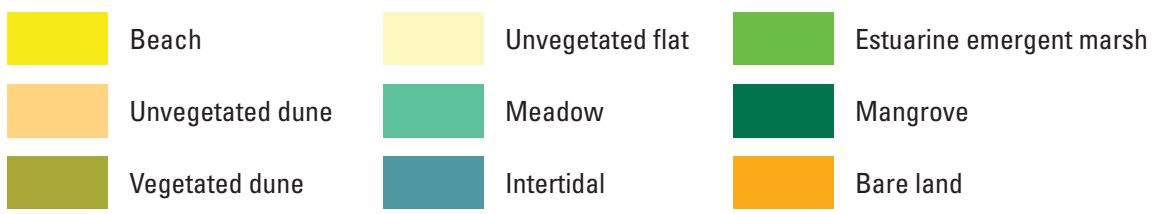

- Approximate vantage point and bearing for oblique photo $(C)$

- Location marker for paired photo comparison

Figure 11. Coverage of detailed habitat classes in an area of the West Chenier Plain region during $A, 2008$ and $B, 2015$, and $C$, paired oblique photographs showing Sabine Pass, 2006 and 2017, used with permission from Westphal (2018). 


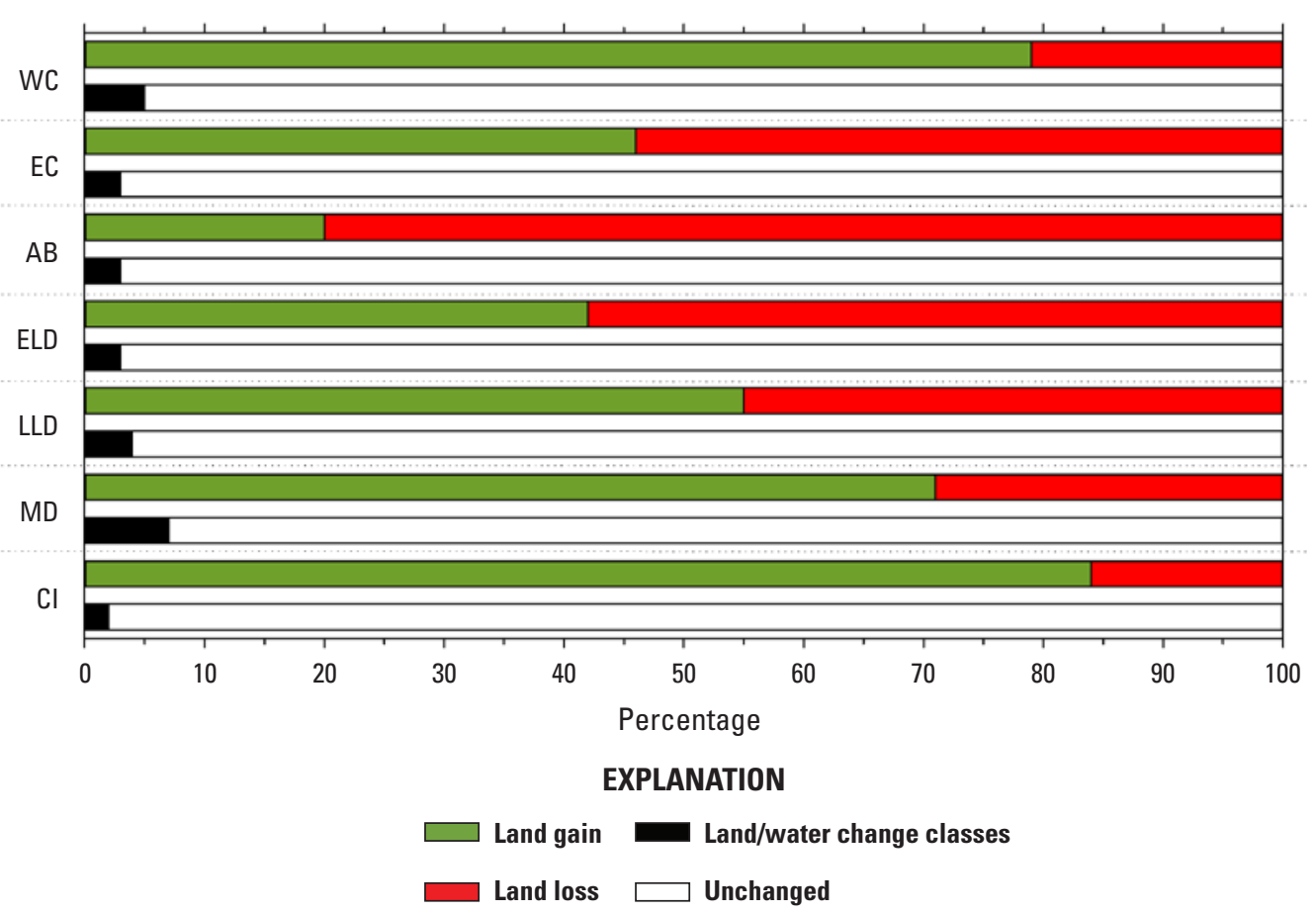

Figure 12. The percentages of areal coverage for land/water change classes (table 5), by Louisiana Barrier Island Comprehensive Monitoring Program region. For each region, the first bar shows the percentage of change made up by each change class, and the second bar shows the percentage of cover for changed and unchanged classes. [WC, West Chenier Plain; EC, East Chenier Plain; AB, Acadiana Bays; ELD, Early Lafourche Delta; LLD, Late Lafourche Delta; MD, Modern Delta; $\mathrm{Cl}$, Chandeleur Islands]

\section{East Chenier Plain Region Habitat and Habitat Change}

For the East Chenier Plain region, the five nonwater detailed habitat classes with the highest areal coverages in 2008 were (1) estuarine emergent marsh $(22,974.94$ ha; 56.8 percent); (2) meadow (543.53 ha; 1.3 percent); (3) grassland (371.40 ha; 0.9 percent); (4) unvegetated flat (296.99 ha; 0.7 percent); and (5) scrub/shrub (292.38 ha; 0.7 percent) (table 1-1; fig. 14). The five nonwater detailed habitat classes with the highest areal coverages in 2015 were (1) estuarine emergent marsh (23,005.50 ha; 56.9 percent); (2) scrub/shrub (614.22 ha; 1.5 percent); (3) meadow (446.89 ha; 1.1 percent); (4) unvegetated flat (180.20 ha; 0.4 percent); and (5) grassland (177.63 ha; 0.4 percent) (table 1-1; fig. 14). Scrub/shrub, shoreline protection, and vegetated dune all had a "high" percent increase (table 10). Increases in scrub/shrub are likely due to post-storm habitat recovery and (or) succession along spoil banks, dune backslopes, and in marshes (fig. 15).
The increase in shoreline protection was associated with the Rockefeller Refuge Gulf Shoreline Protection Demonstration Project (table 2) and some additional breakwater construction projects in the Chenier Au Tigre and Rainey Refuge reaches. The increase in vegetated dune appears to be associated with habitat succession in the eastern part of the region (that is, the Chenier Au Tigre and Rainey Refuge reaches). Beach, grassland, intertidal, and unvegetated flat all had a "high" percent decrease (table 10). Similar to the beach in the West Chenier region, the beach was wider in 2008 than in 2015 (fig. 15). The shoreline for this region rapidly receded from 2004 to 2012 $(-7.3 \mathrm{~m} / \mathrm{yr})$, which is similar to some of the regions in the Deltaic Plain (Byrnes and others, 2018). Additionally, some of the areas that were beach in 2008 have converted to intertidal or estuarine emergent marsh, which is common for post-storm recovery with an extended period of quiescent conditions (fig. 15). The coastal processes of erosion and post-storm succession, along with a lack of sediment supply to offset the erosion, are expected to be the major factors leading to the 


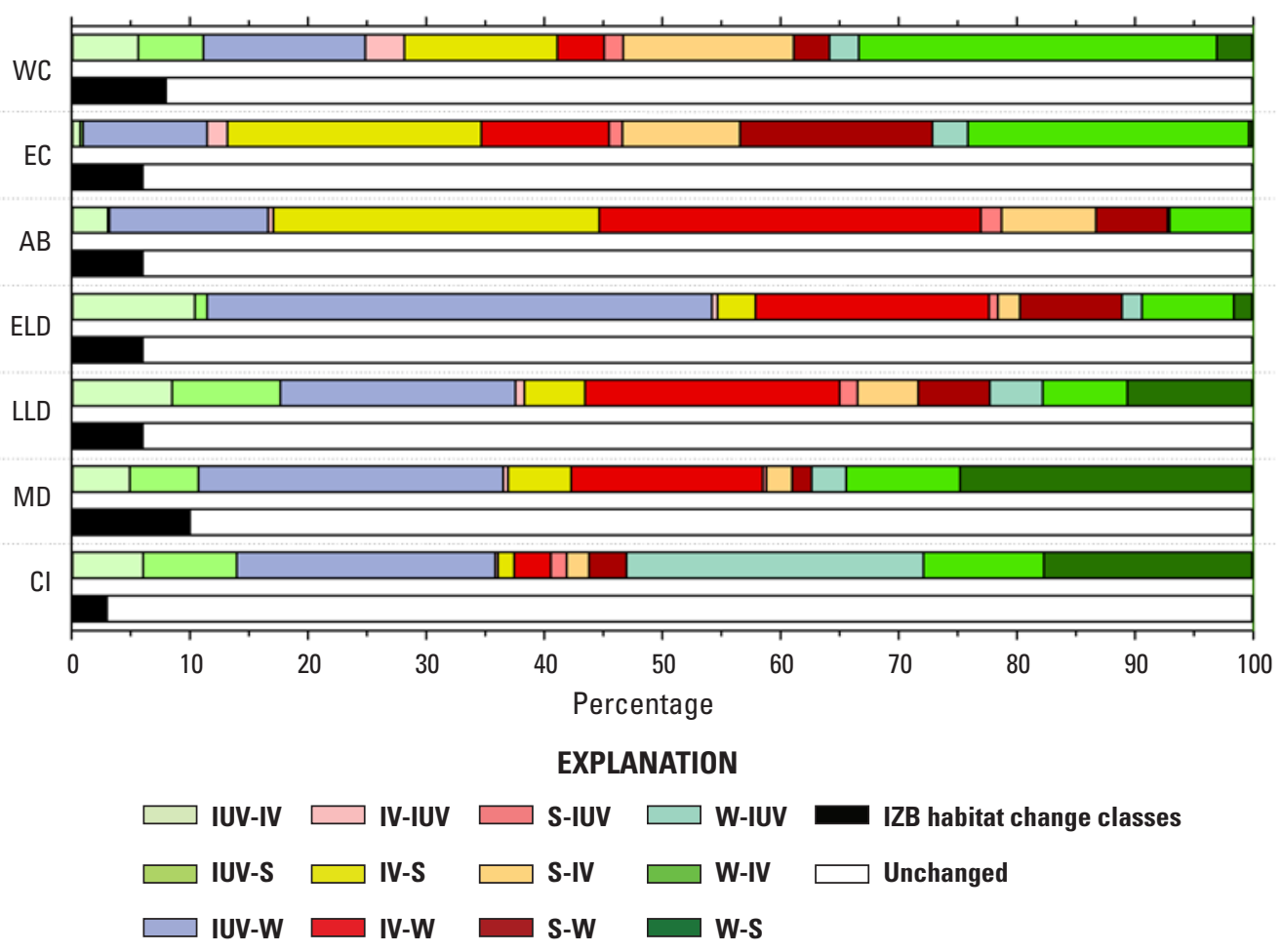

Figure 13. The percentages of areal coverage for inundation zone-based (IZB) habitat change classes (table 6), by Louisiana Barrier Island Comprehensive Monitoring Program region. For each region, the first bar shows the percentage of change made up by each change class, and the second bar shows the percentage of cover for changed and unchanged classes. [WC, West Chenier Plain; EC, East Chenier Plain; AB, Acadiana Bays; ELD, Early Lafourche Delta; LLD, Late Lafourche Delta; MD, Modern Delta; CI, Chandeleur Islands IUV-IV, intertidal-unvegetated to intertidal-vegetated; IUV-S, intertidal-unvegetated to supratidal/upland; IUV-W, intertidal-unvegetated to water; IV-IUV, intertidal vegetated to intertidal-unvegetated; IV-S, intertidal-vegetated to supratidal/upland; IV-W, intertidal-vegetated to water; S-IUV, supratidal/upland to intertidal-unvegetated; S-IV, supratidal/upland to intertidal-vegetated; S-W, supratidal/upland to water; W-IUV, water to intertidal-unvegetated; W-IV, water to intertidal-vegetated; W-S, water to supratidal/upland]

loss of beach habitat in this region. The decline in grassland habitat seems to be largely due to habitat succession. The bulk of the intertidal change is along the shoreline, with some areas concentrated in the parts of the Rockefeller Refuge reach. It can be assumed that these decreases are largely due to coastal processes (that is, shoreline erosion) and water level differences between the two images (that is, surf level along the shoreline and water level in Flat Lake [not shown]). Finally, the unvegetated flat decreases seem to be largely due to habitat succession on overwash areas along the shoreline, especially for a large area in the eastern part of the Mulberry Island reach.
The area experiencing a change in a land/water category for this region was 3.3 percent (table 1-3). Of this change, 45.7 percent was land gain, and 54.3 percent was land loss (fig. 12). This change is supported by the high rate of shoreline erosion for this reach from 2004 to 2012 (Byrnes and others, 2018). For the IZB change, the changed classes accounted for 5.9 percent of the region (table 1-4). These IZB change classes had a "high" coverage (1) water to intertidalvegetated (23.8 percent); (2) intertidal-vegetated to supratidal/upland (21.5 percent); (3) supratidal/upland to water (16.3 percent); (4) intertidal-vegetated to water (10.8 percent); 


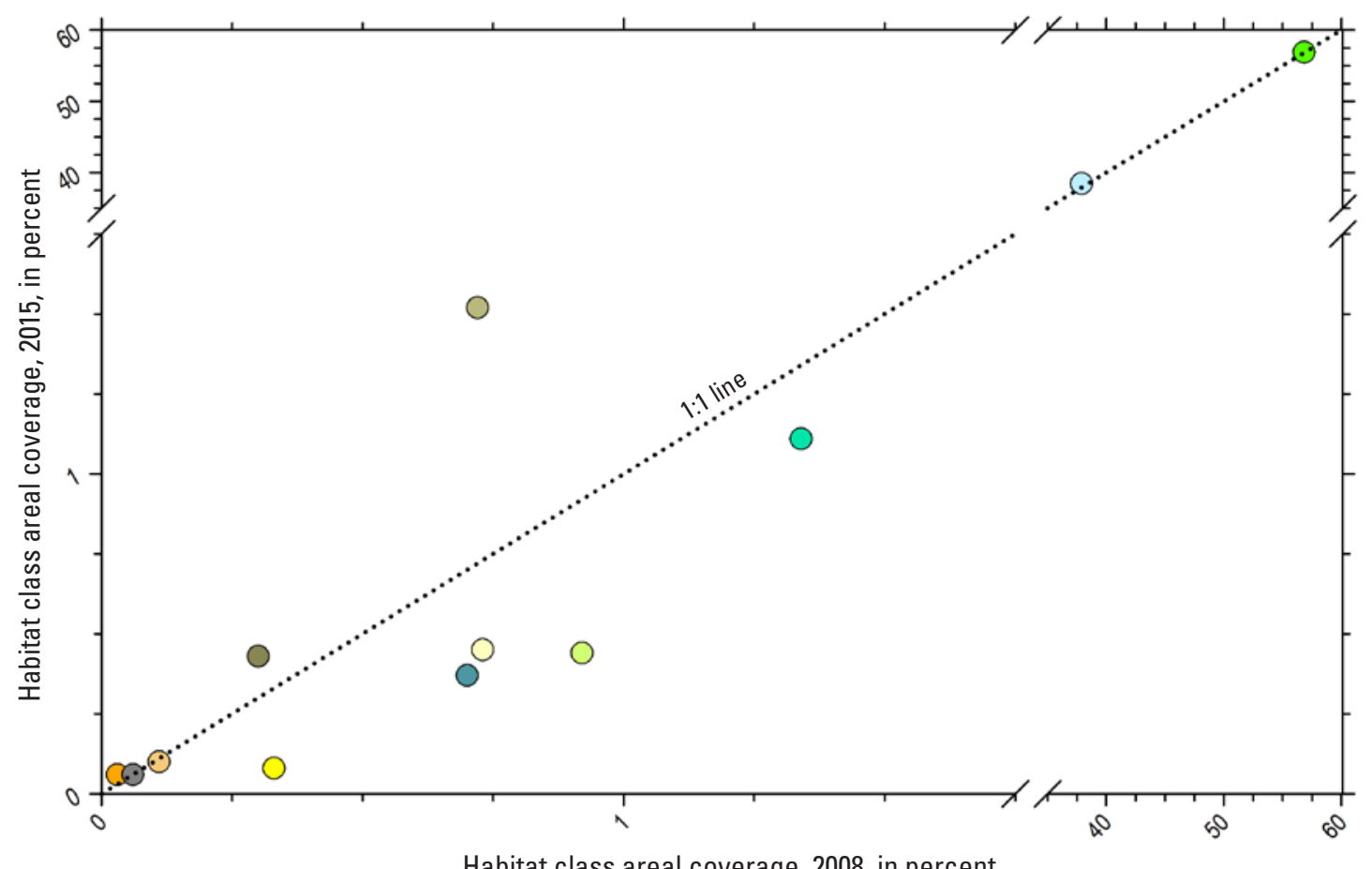

Habitat class areal coverage, 2008, in percent

EXPLANATION

$\begin{array}{lllll}\text { Bare land } & \bigcirc \text { Estuarine emergent marsh } & \bigcirc \text { Intertidal } & \bigcirc \text { Scrub/shrub } & \text { Unvegetated flat } \\ \text { Beach } & \bigcirc \text { Forest } & \bigcirc \text { Mangrove* } & \text { Shoreline protection* } & \bigcirc \text { Vegetated dune* } \\ \text { Developed } & \bigcirc \text { Grassland } & \bigcirc \text { Meadow } & \bigcirc \text { Unvegetated dune } & \bigcirc \text { Water } \\ & & & \end{array}$

Figure 14. Percentages of habitat class areal coverage in the East Chenier Plain region mapped during the Louisiana Barrier Island Comprehensive Monitoring Program, 2008 and 2015. Points that are off the 1:1 line represent change in coverage between the time periods.

(5) intertidal-unvegetated to water (10.5 percent); and (6) supratidal/upland to intertidal-vegetated (10.0 percent) (fig. 13). The water to intertidal-vegetated change was largely due to expansion of emergent marsh at the expense of marsh ponds, and to a lesser extent, terrace development in Rockefeller State Wildlife Refuge and Game Preserve in Round Lake (not shown). The change from intertidalvegetated to supratidal/upland seemed to be from increased detection of linear spoil bank features. As previously stated, these "new" features could be detected because of actual change or increased lidar quality for the 2015 habitat map (table 4). Similarly, some areas with habitat succession and scrub/shrub development would change the area from intertidal-vegetated to supratidal/upland based on the IZB change classification scheme. The supratidal/upland to water change was largely due to the high shoreline erosion rate. As an example, a spit in front of Flat Lake on the eastern portion of the Rockefeller Refuge reach was eroded between 2008 and 2015. Intertidal-vegetated to water change was also highest in the Rockefeller Refuge reach. As previously mentioned, the intertidal-unvegetated to water change was largely due to water level differences between 2008 and 2015. Finally, the supratidal/upland to intertidal-vegetated change occurred along spoil banks, the previously mentioned overwash area in Mulberry Island, near chenier ridges, along the landward edge of meadow (that is, backslopes), and near some developed areas. The changes along spoil banks could indicate spoil bank degradation, yet, besides the change related to the overwash area in Mulberry Island, much of all the change for this class could be due to differences in lidar quality between the dates. 

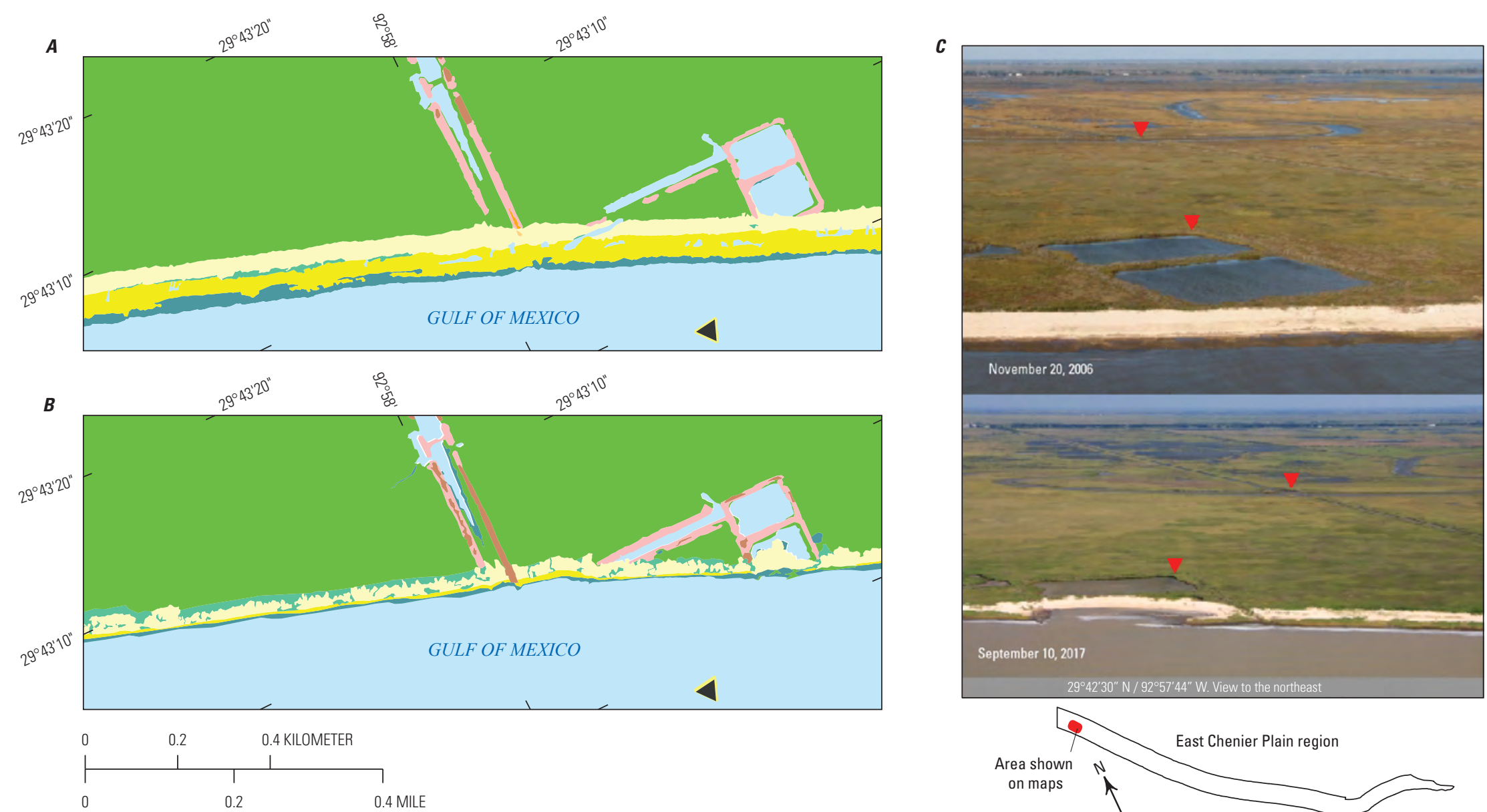

\section{EXPLANATION}

Detailed habitat classes

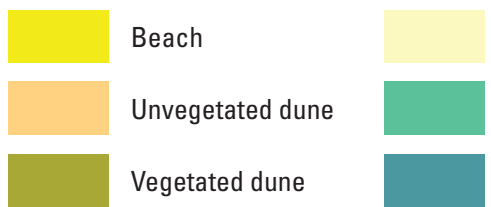

\begin{tabular}{l|l} 
Unvegetated flat & Estuarine emergent marsh \\
Meadow & Mangrove \\
\hline Intertidal & Bare land \\
\hline
\end{tabular}

- Approximate vantage point and bearing for oblique photo $(C)$

$\nabla$ Location marker for paired photo comparison

Figure 15. Coverage of detailed habitat classes in an area of the East Chenier Plain region during $A, 2008$ and B, 2015, and $C$, paired oblique photographs, 2006 and 2017, used with permission from Westphal (2018). 


\section{Acadiana Bays Region Habitat and Habitat Change}

For the Acadiana Bays region, the five nonwater detailed habitat classes with the highest areal coverages in 2008 were

(1) estuarine emergent marsh (5,745.33 ha; 61.5 percent);

(2) meadow (362.11 ha; 3.9 percent); (3) intertidal (90.83 ha;

1.0 percent); (4) grassland ( 22.86 ha; 0.2 percent); and

(5) scrub/shrub (12.65 ha; 0.1 percent) (table 1-1; fig. 16).

The five nonwater detailed habitat classes with the highest areal coverages in 2015-16 were (1) estuarine emergent marsh (5,525.91 ha; 59.2 percent); (2) meadow (426.56 ha; 4.6 percent); (3) scrub/shrub (24.58 ha; 0.3 percent); (4) vegetated dune (13.90 ha; 0.1 percent); and (5) intertidal (13.81 ha;

0.1 percent) (table $1-1$; fig. 16). Bare land and scrub/shrub had "high" percent increases (table 10). The bare land and scrub/ shrub increases were due to spoil bank maintenance along several canals and vegetation succession along undisturbed canals, respectively. Grassland, intertidal, and unvegetated dune had "high" percent decreases (table 10). Mirroring the increase in scrub/shrub, grassland areas changed to scrub/ shrub along some spoil banks. The intertidal decrease (fig. 17) is largely due to water level differences between the dates because many mudflats were evident in marsh ponds for 2008, but not for 2015-16. The decrease in unvegetated dune was largely due to habitat succession on dunes in the western portion of the Marsh Island reach.

The area experiencing a change in a land/water category for this region was 2.8 percent (table 1-3). Of this change, 20.3 percent was land gain, and 79.7 percent was land loss (fig. 12). This region experienced the highest relative percent loss of land for all regions. Some of this change is from a low rate ( 0 to $3 \mathrm{~m} / \mathrm{yr}$ ) of shoreline erosion for this reach from 2004 to 2012 (Byrnes and others, 2018), although most of the change is from loss of emergent marsh to open water. For the IZB change, the changed classes accounted for 5.5 percent of the region (table 1-4). These IZB change classes had a "high" coverage (1) intertidal-vegetated to water (32.3 percent);

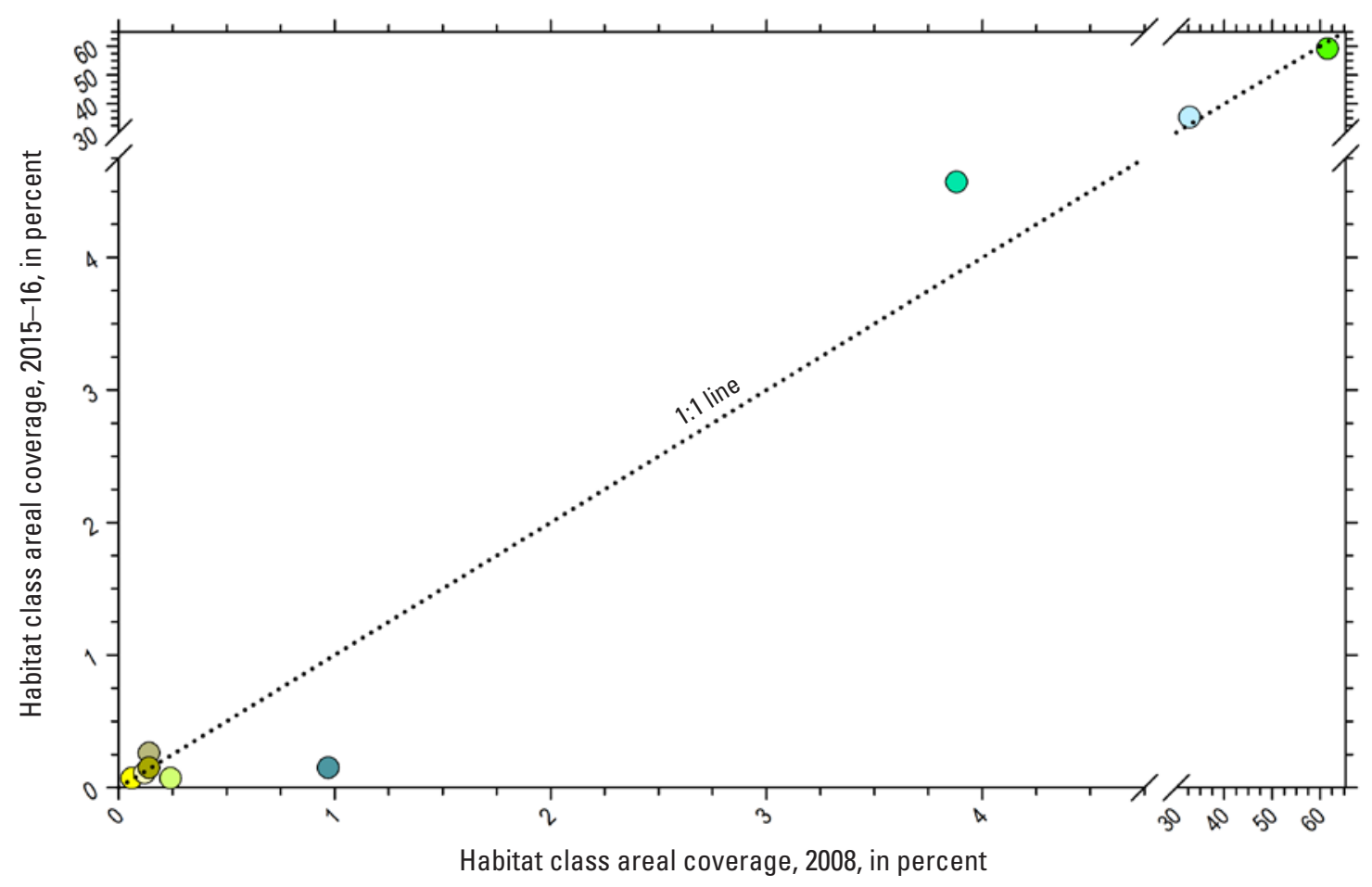

EXPLANATION

\begin{tabular}{|c|c|c|c|c|}
\hline Bare land* & Estuarine emergent marsh & Intertidal & Scrub/shrub & Unvegetated flat \\
\hline Beach & Forest* & Mangrove* & Shoreline protection* & Vegetated dune \\
\hline Developed* & Grassland & Meadow & Unvegetated dune* & Water \\
\hline
\end{tabular}

Figure 16. Percentages of habitat class areal coverage in the Acadiana Bays region mapped during the Louisiana Barrier Island Comprehensive Monitoring Program, 2008 and 2015-16. Points that are off the 1:1 line represent change in coverage between the time periods. 

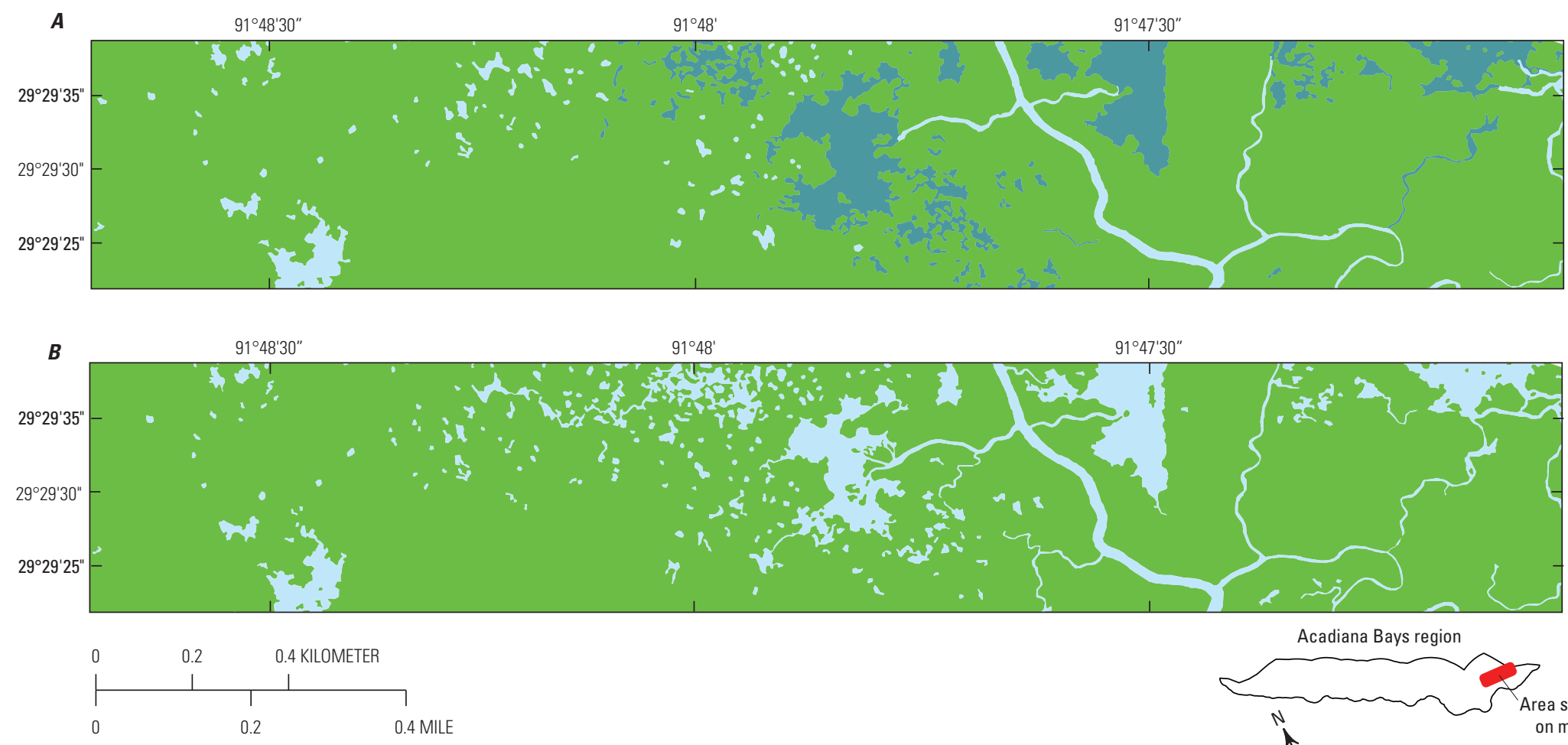

EXPLANATION

Detailed habitat classes

\begin{tabular}{|l|l|l|l|l|l|}
\hline & & Unvegetated flat & Estuarine emergent marsh & Grassland & Shoreline protection \\
\hline Beach & Meadow & Mangrove & Scrub/shrub \\
\hline Uegetated dune & Intertidal & Bare land & Foveloped & Fater \\
\hline
\end{tabular}

Figure 17. Coverage of detailed habitat classes in an area of the Acadiana Bays region during $A, 2008$ and $B, 2015-16$. 
(2) intertidal-vegetated to supratidal/upland (27.6 percent); and (3) intertidal-unvegetated to water (13.4 percent) (fig. 13). As previously mentioned, a large amount of the change in this reach/region was attributed to loss of marsh to open water. The change from intertidal-vegetated to supratidal/upland occurred along the landward edge of meadow habitat. This could have been a result of overwash; however, the limited number of extreme storms suggests that these differences could be largely based on differences in lidar data quality. Finally, the changes from intertidal-unvegetated to water were largely due to water level variability in marsh ponds.

\section{Early Lafourche Delta Region Habitat and Habitat Change}

For the Early Lafourche Delta region, the five nonwater detailed habitat classes with the highest areal coverages in 2008 were (1) estuarine emergent marsh $(8,436.06$ ha; 23.3 percent); (2) intertidal (1,328.15 ha; 3.7 percent); (3) mangrove (340.03 ha; 0.9 percent); (4) unvegetated flat
(200.40 ha; 0.6 percent); and (5) beach (96.76 ha; 0.3 percent) (table 1-1; fig. 18). The five nonwater detailed habitat classes with the highest areal coverages in 2016 were (1) estuarine emergent marsh (8,037.72 ha; 22.2 percent); (2) mangrove (677.45 ha; 1.9 percent); (3) meadow (184.73 ha; 0.5 percent); (4) intertidal (89.76 ha; 0.2 percent); and (5) scrub/shrub (83.19 ha; 0.2 percent) (table $1-1$; fig. 18). Meadow, vegetated dune, and mangrove had "high" percent increases (table 10). The increase in meadow and vegetated dune was largely due to habitat succession associated with restoration efforts for Raccoon Island (fig. 19), Whiskey Island, Trinity Island, and East Island reaches where unvegetated flat and unvegetated dune changed to meadow and vegetated dune, respectively. Mangrove expansion into estuarine emergent marsh accounted for the increase in mangrove habitat (fig. 19). Beach, intertidal, grassland, unvegetated dune, and unvegetated flat had "high" percent decreases (table 10). Similar to the beaches in regions to the west, the beach was wider in 2008 than in 2016, which was likely due to the system being out of equilibrium after the extreme storms (table 1). The westernmost

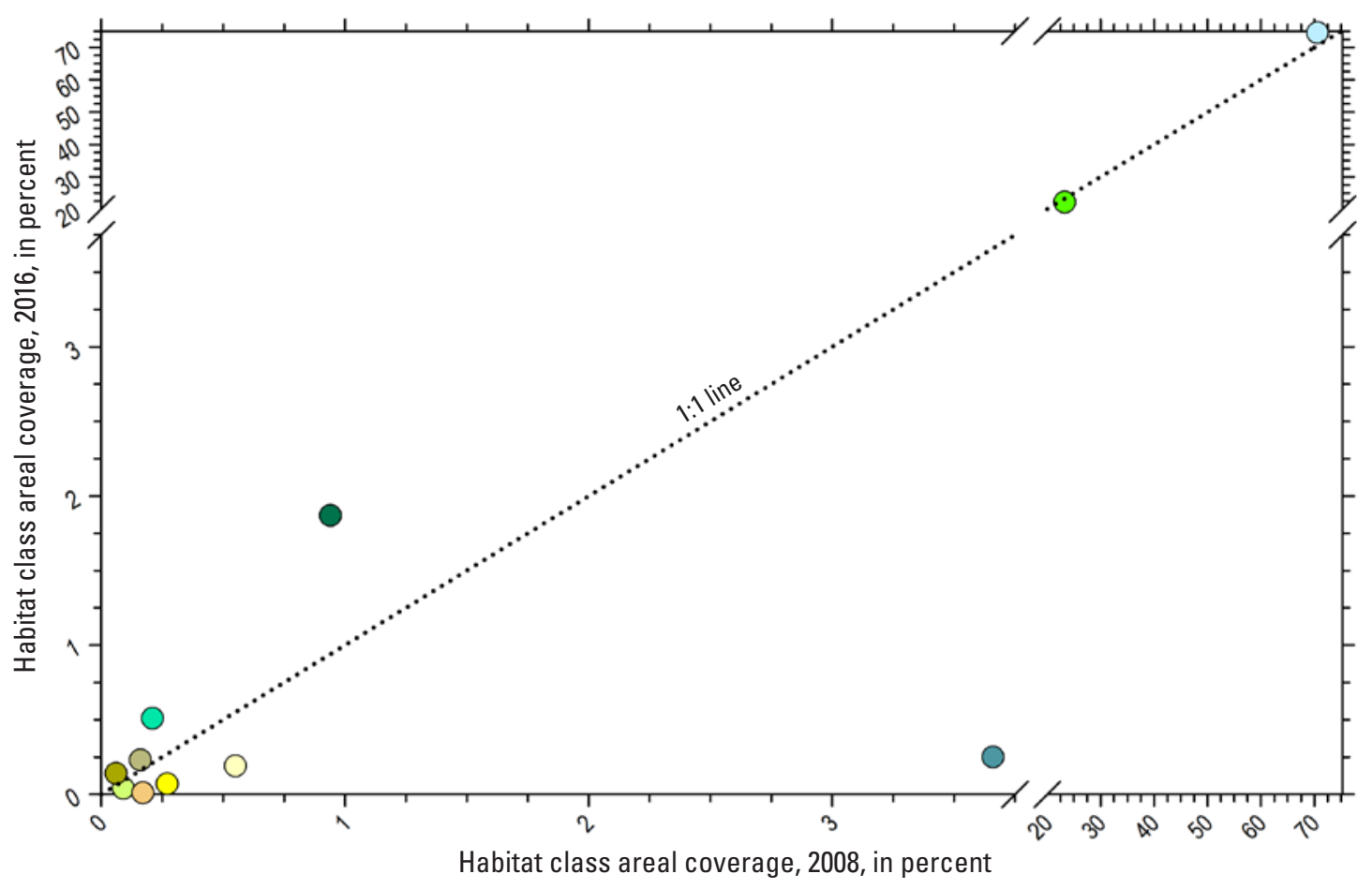

EXPLANATION

\begin{tabular}{|c|c|c|c|c|}
\hline Bare land* & Estuarine emergent marsh & Intertidal & Scrub/shrub & Unvegetated flat \\
\hline Beach & Forest* & Mangrove & Shoreline protection* & Vegetated dune \\
\hline Developed* & $\bigcirc$ Grassland & Meadow & $\bigcirc$ Unvegetated dune & Water \\
\hline
\end{tabular}

Figure 18. Percentages of habitat class areal coverage in the Early Lafourche Delta region mapped during the Louisiana Barrier Island Comprehensive Monitoring Program, 2008 and 2016. Points that are off the 1:1 line represent change in coverage between the time periods. 

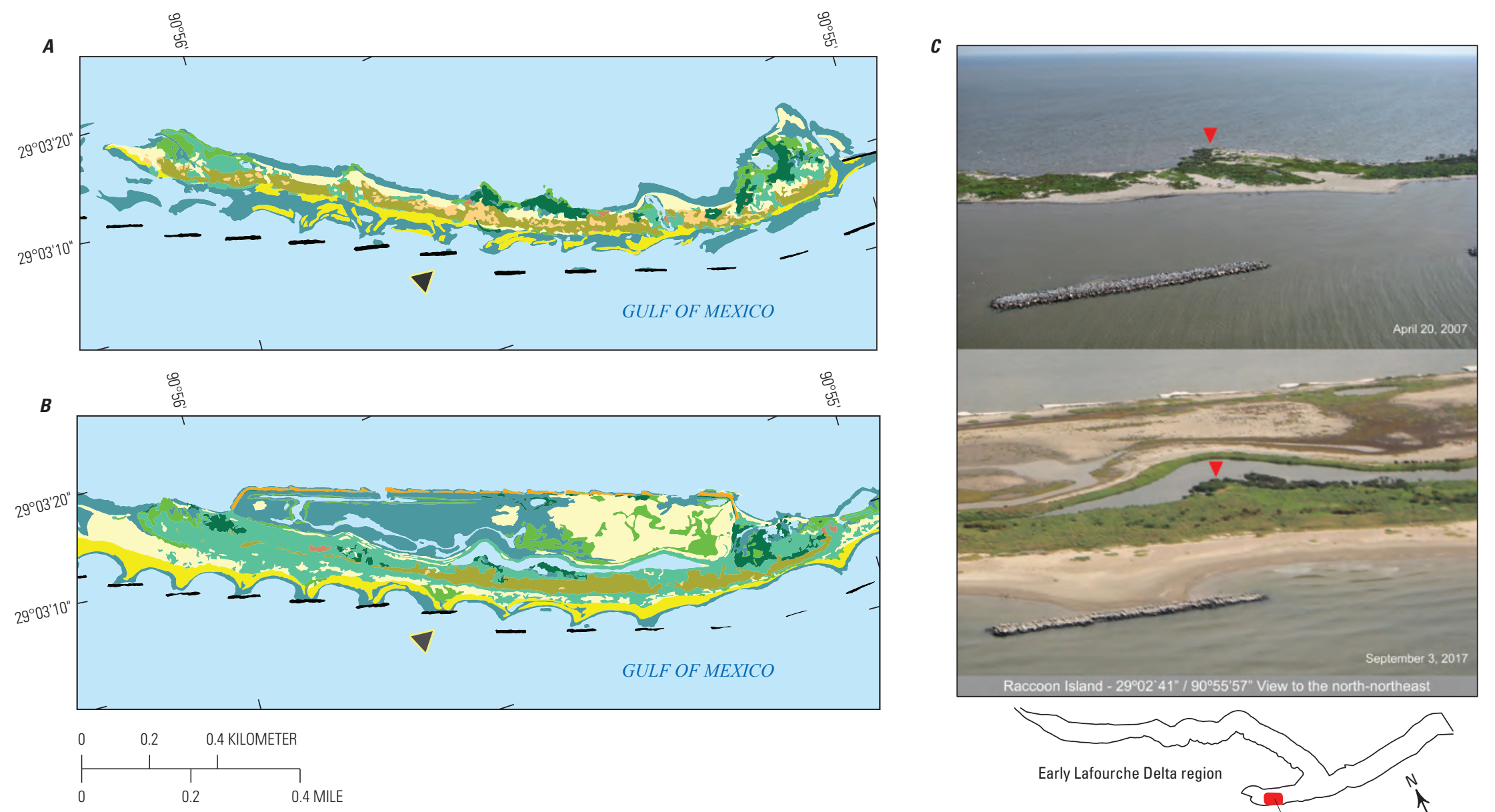

\section{EXPLANATION}

\section{Detailed habitat classes}

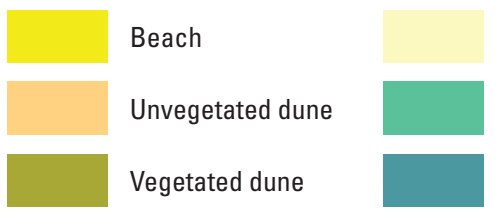

\begin{tabular}{|c|c|}
\hline Unvegetated flat & Estuarine emergent marsh \\
\hline Meadow & Mangrove \\
\hline & Bare land \\
\hline
\end{tabular}

A Approximate vantage point and bearing for oblique photo $(C)$

$\nabla$ Location marker for paired photo comparison

Figure 19. Coverage of detailed habitat classes in an area of the Early Lafourche Delta region during $A, 2008$ and $B, 2016$, and $C$, paired oblique photographs, 2007 and 2017, used with permission from Westphal (2018).
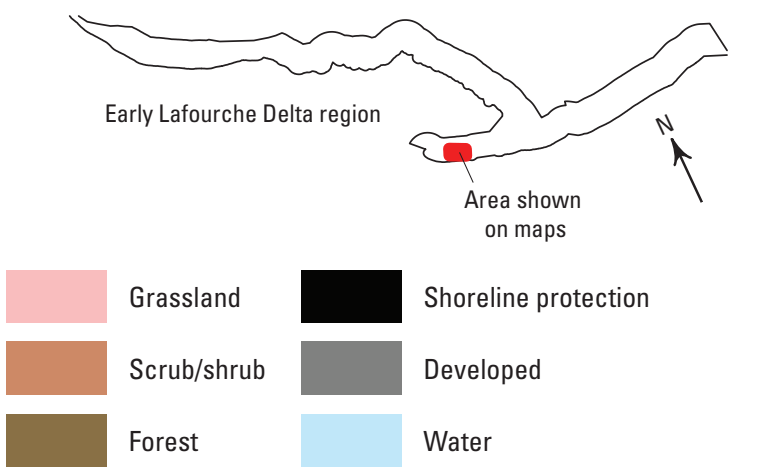
reaches have a marsh-dominated shoreline (that is, Point $\mathrm{Au}$ Fer Island and Oyster Bayou to Caillou Boca), whereas the remainder of the reaches are wave-dominated barrier islands. The decline of beach habitat for these barrier island reaches (that, is Raccoon, Whiskey, Trinity, East, and Wine Islands) is not surprising given the high shoreline erosion rates from 2004 to 2012, which ranged from $2.7 \mathrm{~m} / \mathrm{yr}$ to $26.8 \mathrm{~m} / \mathrm{yr}$, with a median of $5.7 \mathrm{~m} / \mathrm{yr}$ (Byrnes and others, 2018). The main reason for the decline of intertidal area was due to water level differences leading to mudflats within marsh ponds and tidal creeks throughout the region being exposed in 2008, but not in 2016. However, some other causes of the intertidal decline were erosion of part of the western spit of Raccoon Island and restoration along the western spit of Whiskey Island. The decline in grassland appeared to be largely associated with habitat succession along spoil banks. The reason for the decline in unvegetated dune and unvegetated flat were previously discussed with regard to the increase in meadow and vegetated dune habitat (fig. 19).

The area experiencing a change in a land/water category for this region was 3.1 percent (table 1-3). Of this change, 41.7 percent was land gain, and 58.3 percent was land loss (fig. 12). For the IZB change, the changed classes accounted for 6.1 percent of the region (table 1-4). These IZB change classes had a "high" percent change (1) intertidal-unvegetated to water (42.7 percent); (2) intertidal-vegetated to water (19.7 percent); and (3) intertidal-unvegetated to intertidalvegetated (10.4 percent) (fig. 13). The intertidal-unvegetated to water change was previously discussed. The intertidalvegetated to water change was largely due to shoreline erosion throughout the whole region, but especially along the marsh shorelines of the westernmost reaches. The intertidalunvegetated to intertidal-vegetated change was largely a result of the marsh restoration effort on Whiskey Island in 2009 (table 2).

\section{Late Lafourche Delta Region Habitat and Habitat Change}

For the Late Lafourche Delta region, the five nonwater detailed habitat classes with the highest areal coverages in 2008 were (1) estuarine emergent marsh $(2,551.91$ ha; 7.8 percent); (2) intertidal (797.97 ha; 2.4 percent); (3) developed (680.23 ha; 2.1 percent); (4) mangrove (582.36 ha; 1.8 percent); and (5) unvegetated flat (323.79 ha; 1.0 percent) (table 1-1; fig. 20). The five nonwater detailed habitat classes with the highest areal coverages in 2016 were (1) estuarine emergent marsh (1,952.63 ha; 6.0 percent); (2) mangrove (1,048.20 ha; 3.2 percent); (3) developed (695.02 ha; 2.1 percent); (4) meadow (478.79 ha; 1.5 percent); and (5) scrub/shrub (265.20 ha; 0.8 percent) (table 1-1; fig. 20). Unvegetated dune and mangrove had "high" percent increases (table 10). The reason for the high increase in unvegetated dune was the Caminada Headland beach and dune restoration (table 2; fig. 21). Mangrove expansion occurred in most

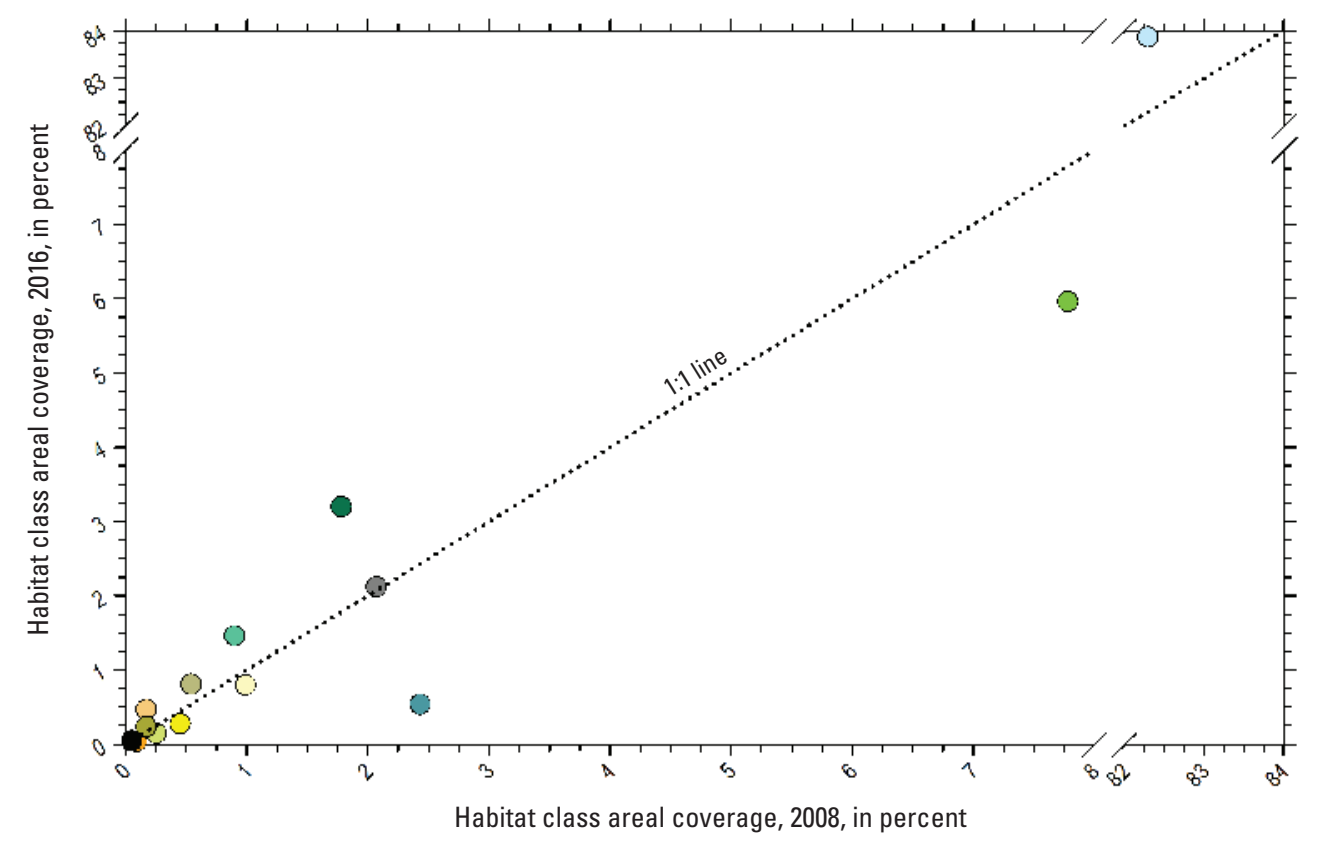

EXPLANATION

$\begin{array}{lllll}\text { OBare land } & \text { O Estuarine emergent marsh } & \text { O Intertidal } & \text { O Scrub/shrub } & \text { O Unvegetated flat } \\ \text { OBeach } & \text { O Forest } & \text { O Mangrove } & \text { O Shoreline protection } & \text { O Vegetated dune } \\ \text { ODeveloped } & \text { O Grassland } & \text { O Meadow } & \text { O Unvegetated dune } & \text { OWater }\end{array}$

Figure 20. Percentages of habitat class areal coverage in the Late Lafourche Delta region mapped during the Louisiana Barrier Island Comprehensive Monitoring Program, 2008 and 2016. Points that are off the 1:1 line represent change in coverage between the time periods. 

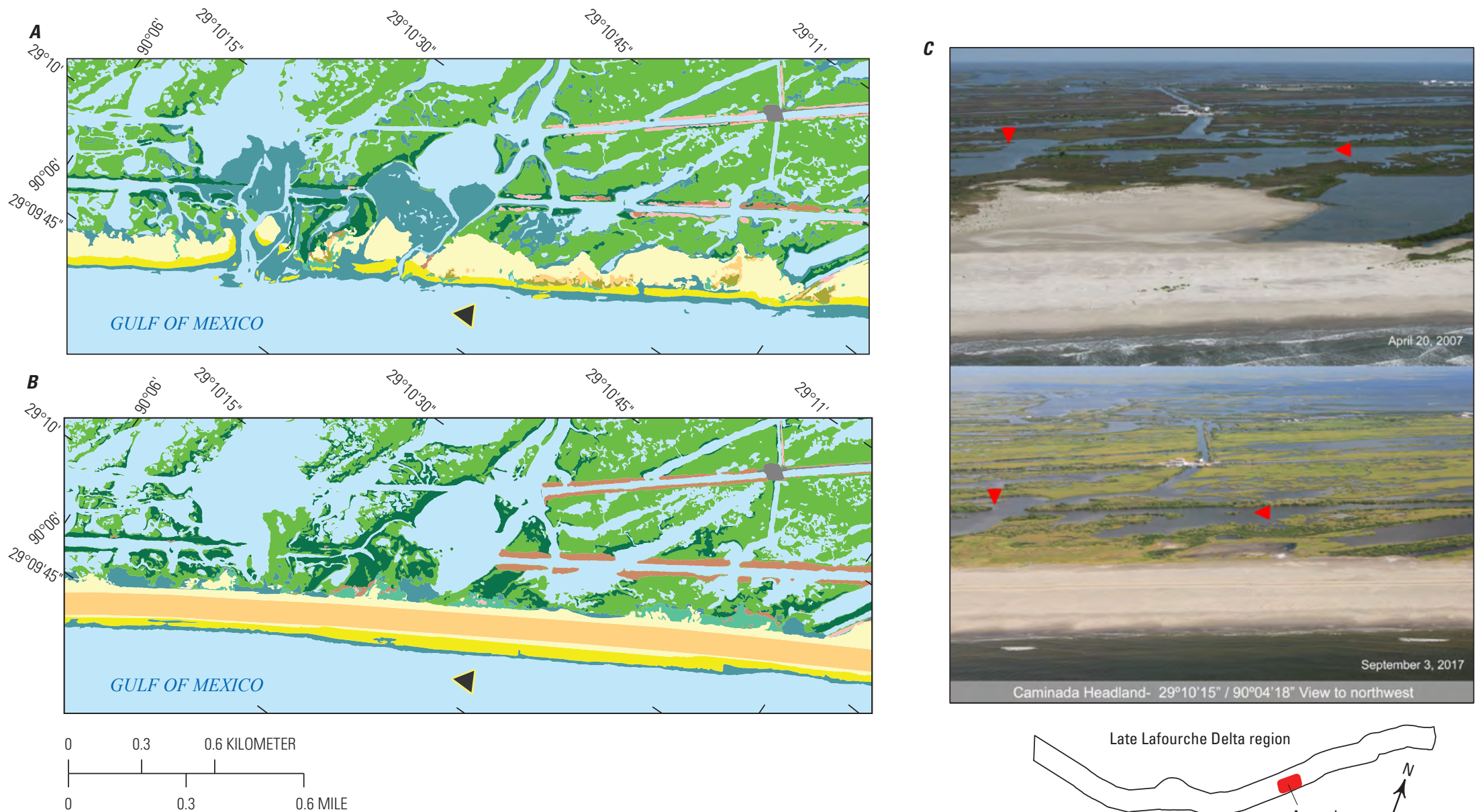

\section{EXPLANATION}

Detailed habitat classes

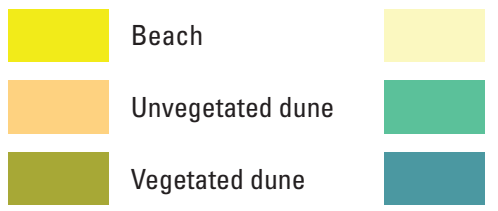

Unvegetated flat
Meadow
Intertidal

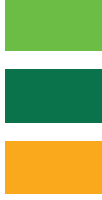

Estuarine emergent marsh

Mangrove

Bare land

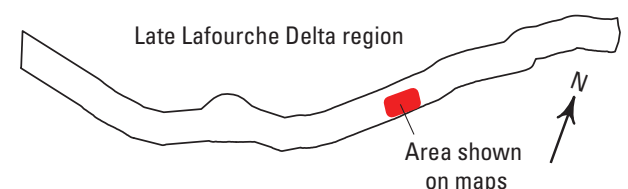

- Approximate vantage point and bearing for oblique photo $(C)$

$\nabla \quad$ Location marker for paired photo comparison

Figure 21. Coverage of detailed habitat classes in an area of the Late Lafourche Delta region during $A, 2008$ and B, 2016, and $C$, paired oblique photographs, 2007 and 2017, used with permission from Westphal (2018). 
of the reaches, with the largest increase along the Caminada Headland (fig. 21). This finding is consistent with a recent study by Osland and others (2017) for this area. Intertidal, bare land, and grassland had "high" percent decreases (table 10). The main reasons for the decline of intertidal area were water level differences leading to mudflats within marsh ponds and tidal creeks throughout the region being exposed in 2008, but not in 2016. Additionally, some intertidal loss was likely driven by recovery after Hurricanes Gustav and Ike (table 1; fig. 21). Habitat succession was the reason for the bulk of the loss of grassland and bare land area (fig. 21).

The area experiencing a change in a land/water category for this region was 4.0 percent (table 1-3). Of this change, 55.1 percent was land gain, and 44.9 percent was land loss (fig. 12). Despite a high shoreline erosion rate from 2004 to 2012 of $6.2 \mathrm{~m} / \mathrm{yr}$ (Byrnes and others, 2018), restoration efforts were likely the major reason for the land gain in this region. For the IZB change, the changed classes accounted for 5.8 percent of the region (table 1-4). These IZB change classes had a "high" percent change (1) intertidalvegetated to water (21.6 percent); (2) intertidal-unvegetated to water (19.9 percent); and (3) water to supratidal/upland (10.6 percent) (fig. 13). The change from intertidal-vegetated to water was largely due to marsh loss to open water and erosion along the back-barrier shorelines. The Grand Isle area has one of the highest relative sea-level rise trends in the United States at about 9.1 millimeters per year based on observations from 1947 to 2018 (Sweet and others, 2017; NOAA, $2019 b$ ), which is likely to be a major factor in the change for both intertidal classes to water. Another likely cause for these changes was erosion of Timbalier and East Timbalier Islands from Hurricane Isaac. Water level differences in marsh ponds and tidal creeks accounted for a large amount of the change from intertidal-unvegetated to water. The change from water to supratidal/upland was likely due to restoration projects on West Belle Pass, East Grand Terre Island, and the previously mentioned Caminada Headland (table 2), along with some localized accretion along the shoreline, especially along island spits and tips.

\section{Modern Delta Region Habitat and Habitat Change}

For the Modern Delta region, the five nonwater detailed habitat classes with the highest areal coverages in 2008 were (1) estuarine emergent marsh (1,404.89 ha; 7.8 percent);
(2) intertidal (718.41 ha; 4.0 percent); (3) unvegetated flat (143.84 ha; 0.8 percent); (4) mangrove (69.83 ha; 0.4 percent); and (5) scrub/shrub (47.08 ha; 0.3 percent) (table 1-1; fig. 22). The five nonwater detailed habitat classes with the highest areal coverages in 2016 were (1) estuarine emergent marsh (1,238.67 ha; 6.9 percent); (2) unvegetated flat (322.63 ha; 1.8 percent); (3) meadow (304.48 ha; 1.7 percent); (4) mangrove (124.29 ha; 0.7 percent); and (5) intertidal ( 84.51 ha; 0.5 percent) (table $1-1$; fig. 22). Grassland, meadow, unvegetated dune, and vegetated dune all had "high" percent increases (table 10). The grassland increase was largely associated with herbaceous vegetation growing on containment dikes (that is, spoil banks) from the various restoration efforts in the Chaland Headland and Shell Island reaches (table 2; fig. 23). These restoration efforts were also likely responsible for the high increases in meadow, unvegetated dune, and vegetated dune because these efforts all included these features in their designs. In addition to the restoration efforts, habitat succession in areas restored in 2007 in Chaland Headland, as well as some other nonrestored areas, may have also been responsible for the increase in meadow habitat. Intertidal was the only class with a "high" percent decrease (table 10). Most of the intertidal changes were due to mudflats being exposed by lower water levels in 2008; however, some change was from restoration efforts throughout the region (table 2), which changed intertidal habitat to supratidal/upland habitats.

The area experiencing a change in a land/water category for this region was 6.6 percent, which was the highest of all regions (table 1-3). Of this change, 70.8 percent was land gain, and 29.2 percent was land loss (fig. 12). Restoration efforts led to a net gain of land despite the high shoreline erosion rate from 2004 to 2012 of $6.4 \mathrm{~m} / \mathrm{yr}$ (Byrnes and others, 2018). For the IZB change, the changed classes accounted for 10.3 percent of the region (table 1-4). These IZB change classes had a "high" percent change (1) intertidal-unvegetated to water (25.8 percent); (2) water to supratidal/upland (24.8 percent); and (3) intertidal-vegetated to water (16.2 percent) (fig. 13). The intertidal-unvegetated to water change was previously discussed. The water to supratidal/upland change likely resulted from several restoration efforts (table 2) and was responsible for the high amount of net gain in this region. Finally, the intertidal-vegetated to water change was from estuarine emergent marsh loss to water throughout the region, but particularly along marsh edges. 


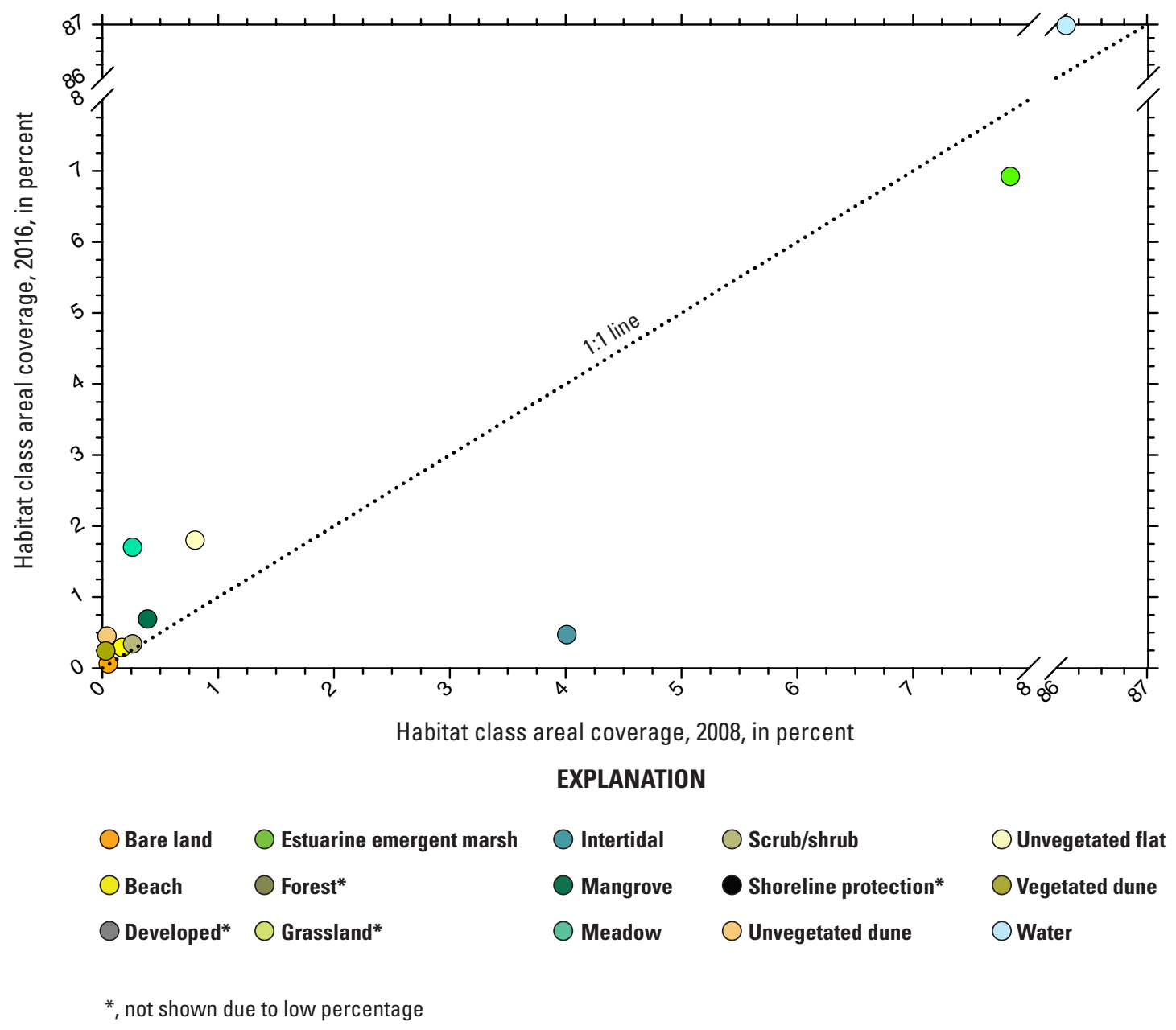

Figure 22. Percentages of habitat class areal coverage in the Modern Delta region mapped during the Louisiana Barrier Island Comprehensive Monitoring Program, 2008 and 2016. Points that are off the 1:1 line represent change in coverage between the time periods. 

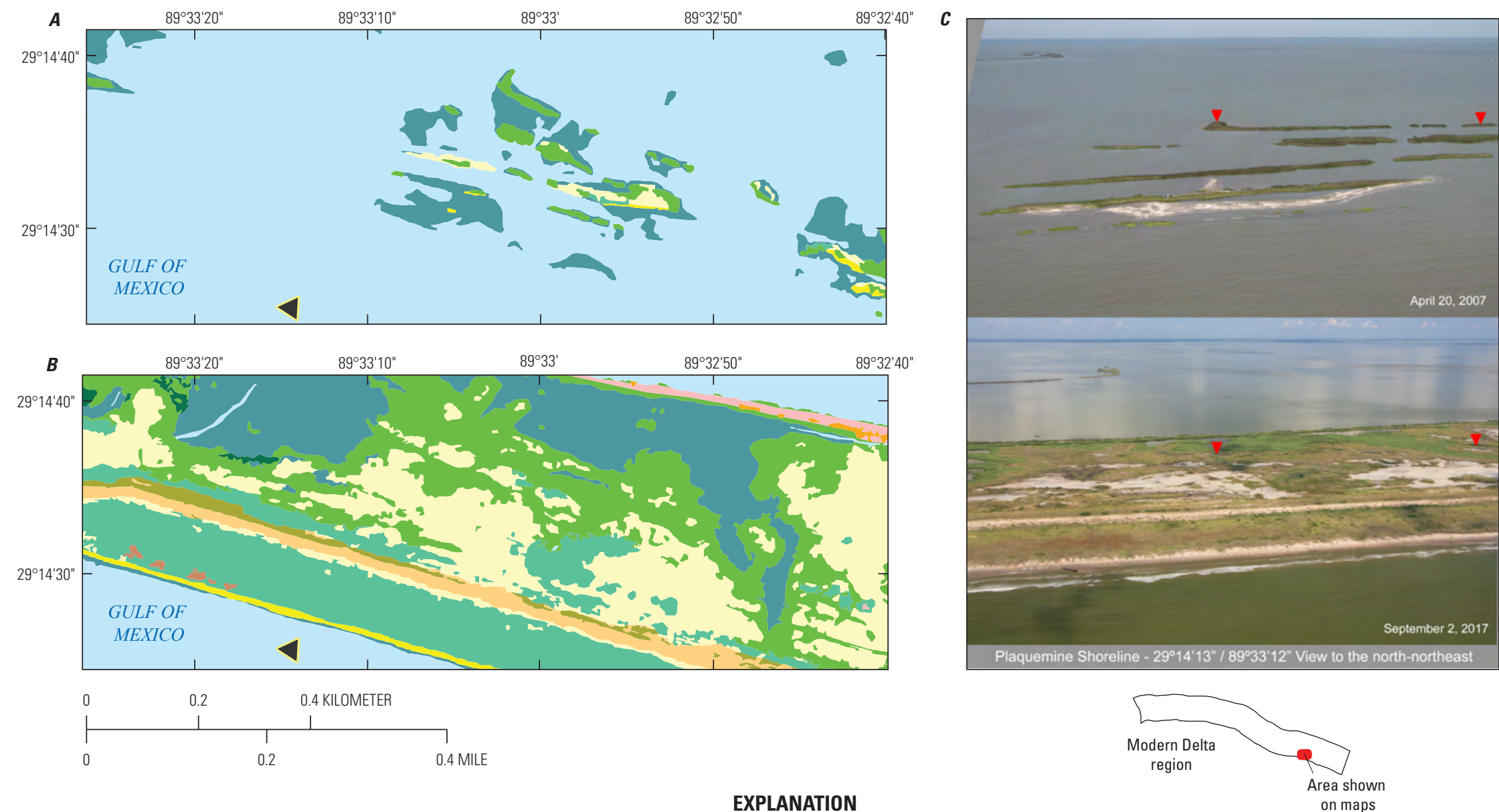

EXPLANATION

Detailed habitat classes
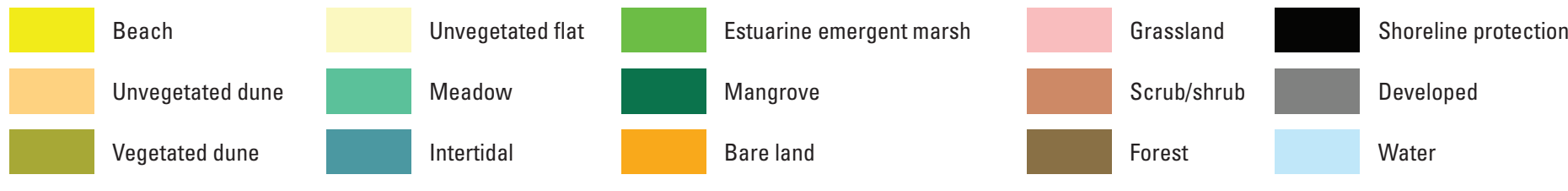

Approximate vantage point and bearing for oblique photo $(C)$

V Location marker for paired photo comparison

Figure 23. Coverage of detailed habitat classes in an area of the Modern Delta region during A, 2008 and B, 2016, and C, paired oblique photographs, 2007 and 2017 , used with permission from Westphal (2018). 


\section{Chandeleur Islands Region Habitat and Habitat Change}

For the Chandeleur Island region, the five nonwater detailed habitat classes with the highest areal coverages in 2008 were (1) intertidal ( 565.50 ha; 1.3 percent); (2) estuarine emergent marsh (156.54 ha; 0.4 percent); (3) unvegetated flat (129.11 ha; 0.3 percent); (4) mangrove (50.01 ha; 0.1 percent); and (5) meadow (22.23 ha; 0.1 percent) (table 1-1; fig. 24). The five nonwater detailed habitat classes with the highest areal coverages in 2016 were (1) intertidal (443.33 ha; 1.1 percent); (2) unvegetated flat (301.74 ha; 0.7 percent); (3) estuarine emergent marsh (294.45 ha; 0.7 percent); (4) mangrove (87.09 ha; 0.2 percent); and (5) meadow (68.76 ha; 0.2 percent) (table 1-1; fig. 24). Beach, meadow, scrub/shrub, unvegetated flat, developed, estuarine emergent marsh, and mangrove all had "high" percent increases (table 10). The increases in beach and unvegetated flat habitats could be attributed to restoration actions in this region in addition to continued recovery from Hurricane Katrina, which severely impacted the Chandeleur Islands (table 2; fig. 25). The increase in estuarine emergent marsh was likely an indirect response of these various previous actions and processes (that is, berms created sheltered areas where habitat succession can occur in back-barrier intertidal flats; fig. 25) along with habitat succession in overwash areas from hurricanes (table 1). Developed and scrub/shrub had a high percent increase, but the magnitude increase was small. The Breton Island reach had a small increase in developed area (that is, 0.14 ha) because of expansion of an oil and gas facility offshore of Breton Island. Habitat succession likely resulted in the increase in meadow and scrub/shrub habitat (fig. 25). Mangrove expansion into estuarine emergent marsh was the likely cause of the increase in mangrove habitat. Bare land, shoreline protection, and unvegetated dune had "high" percent decreases (table 10). Both bare land and shoreline protection had a "high" percent decrease, but the magnitude of change was very low (that is, 0.04 ha and 0.06 ha, respectively). The decrease in

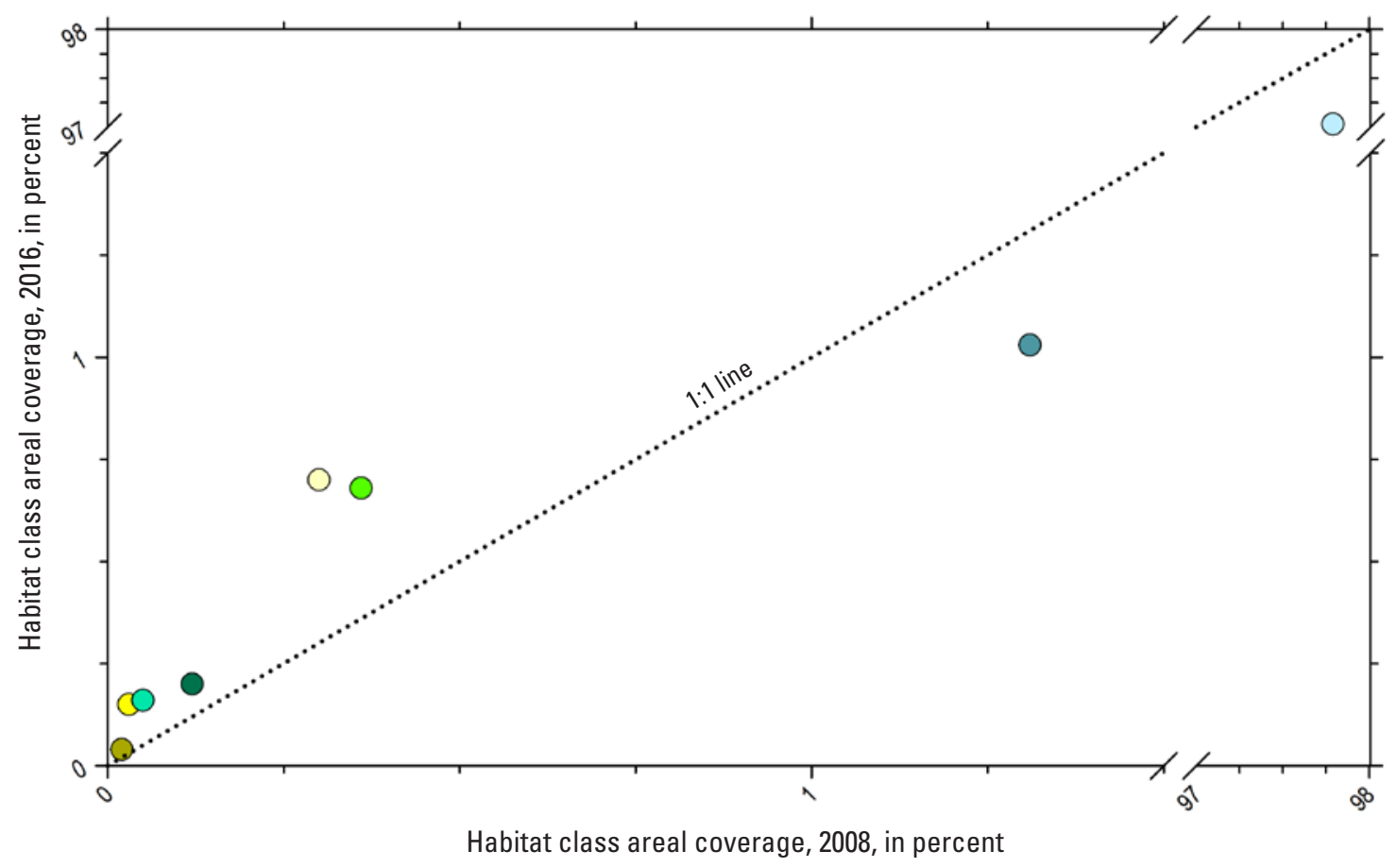

EXPLANATION

\begin{tabular}{|c|c|c|c|c|}
\hline Bare land* & Estuarine emergent marsh & Intertidal & Scrub/shrub* & $\bigcirc$ Unvegetated flat \\
\hline Beach & Forest* & Mangrove & Shoreline protection* & Vegetated dune \\
\hline Developed* & Grassland* & Meadow & Unvegetated dune* & Water \\
\hline
\end{tabular}

${ }^{*}$, not shown due to low percentage

Figure 24. Percentages of habitat class areal coverage in the Chandeleur Islands region mapped during the Louisiana Barrier Island Comprehensive Monitoring Program, 2008 and 2016. Points that are off the 1:1 line represent change in coverage between the time periods. 

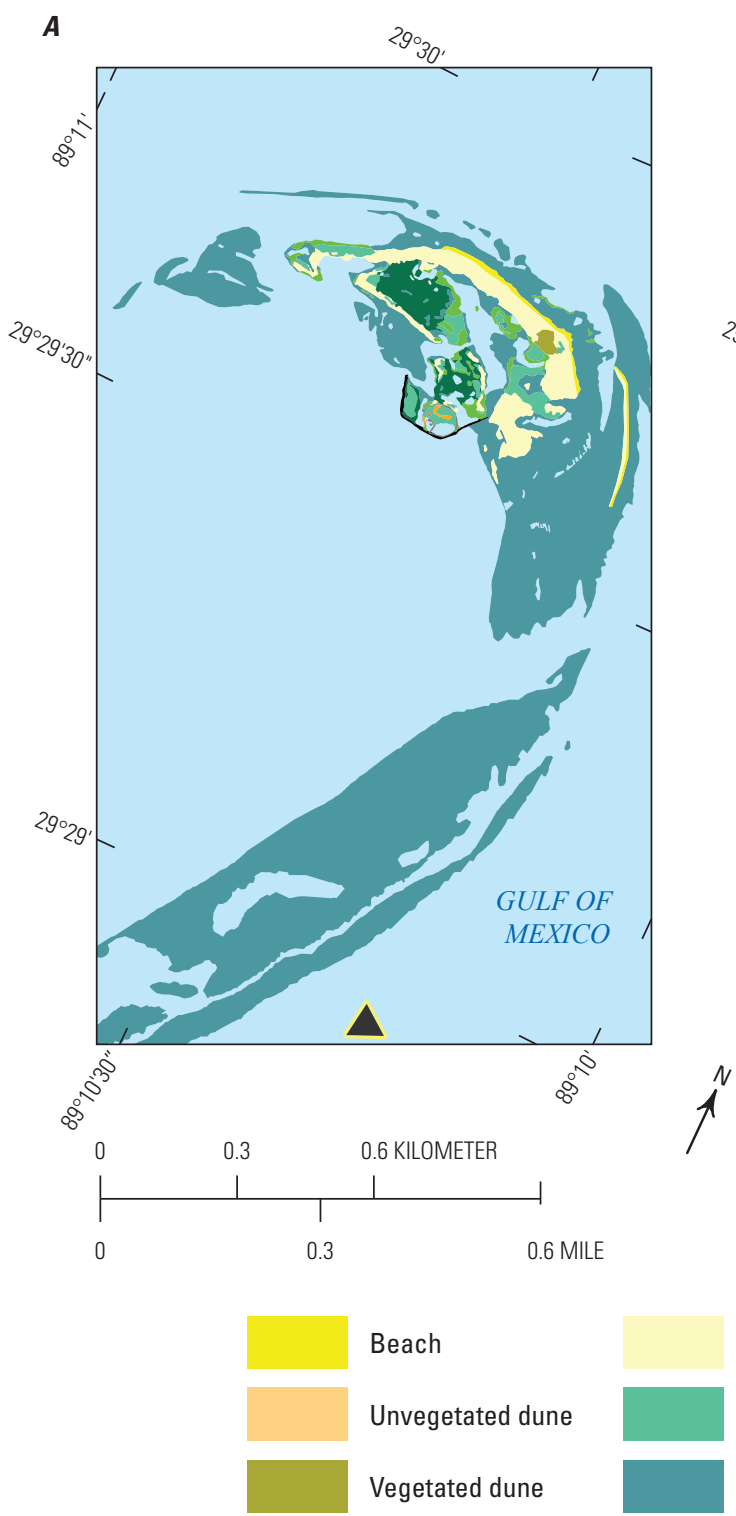

B

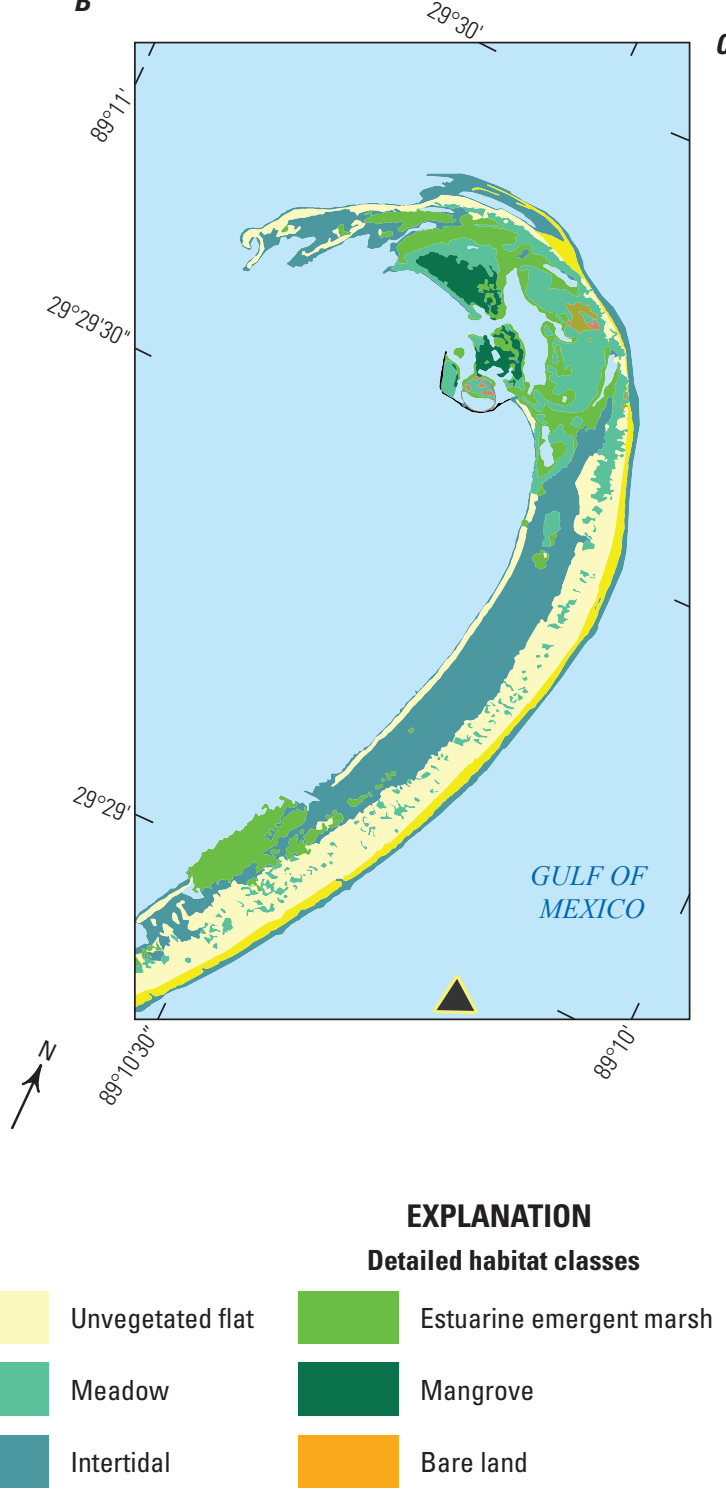

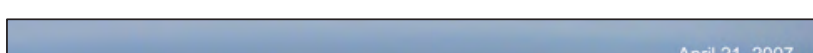
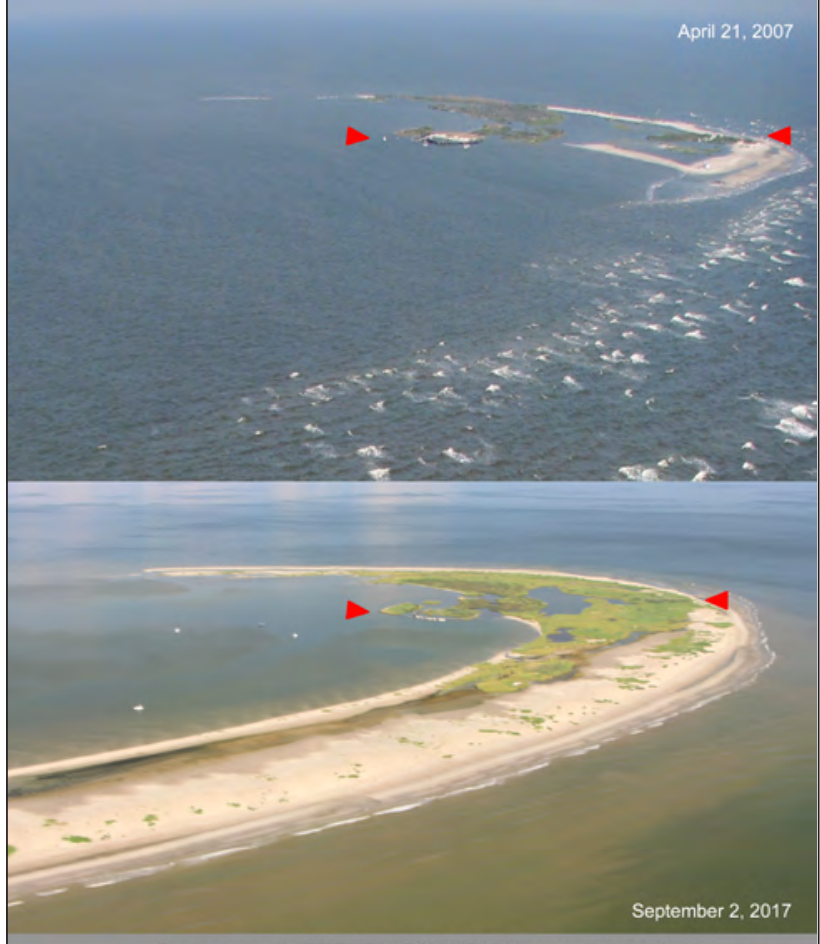

Breton Island $29^{\circ} 29^{\prime} 7^{\prime \prime} / 89^{\circ} 1001^{\prime \prime}$ View to the noth
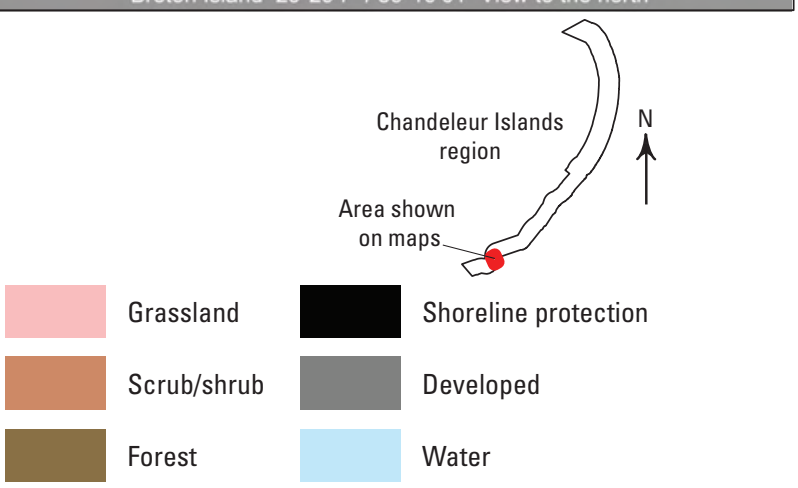

Forest

- Approximate vantage point and bearing for oblique photo $(C)$

$\nabla \quad$ Location marker for paired photo comparison

Figure 25. Coverage of detailed habitat classes in an area of the Chandeleur Islands region during $A, 2008$ and $B, 2016$, and $C$, paired oblique photographs, 2006 and 2017, used with permission from Westphal (2018). 
unvegetated dune was largely due to habitat succession and the dynamic nature of conditions in the Chandeluer Island reach. For example, as overwash fans became vegetated and cut off the nearby sand supply to some of the more landward dunes, these areas changed to meadow per the BICM classification scheme (table 3; fig. 25). The shoreline protection decrease is likely related to the degradation and (or) burial of engineering structures in the Breton Island reach.

The area experiencing a change in a land/water category for this region was 1.5 percent (table 1-3), which was the lowest of all regions. Of this change, 84.3 percent was land gain, and 15.7 percent was land loss (fig. 12). Similar to the Late Lafourche Delta and Modern Delta regions, restoration efforts and natural recovery have led to a net gain of land but also the highest shoreline erosion rate of all the BICM regions from 2004 to 2012 at $41.2 \mathrm{~m} / \mathrm{yr}$ (Byrnes and others, 2018). For the IZB change, the changed classes accounted for 3.1 percent of the region (table 1-4). These IZB change classes had a "high" percent change (1) water to intertidal-unvegetated (25.2 percent); (2) intertidal-unvegetated to water (21.9 percent); (3) water to supratidal/land (17.7 percent); and (4) water to intertidal-vegetated (10.2 percent) (fig. 13). The water to intertidal-unvegetated change was likely due to natural recovery and overwash associated with Hurricane Isaac in the Breton, Grand Gosier, and Curlew Island reaches because no major restoration efforts occurred in these areas between 2008 and 2016. The intertidal-unvegetated to water change was largely due to shoreline erosion moving the island chain westward. This change was most notable in the Breton Island reach and the north Chandeleur Islands reach, but this may also be due to water levels at the time of photo acquisition, as noted for other regions. In addition to loss of intertidal-unvegetated area along the high energy shoreline, there was also substantial loss along the back-barrier shoreline in the north Chandeleur Islands reach. Water to supratidal/upland changes are a result of the berm restoration efforts in this region (table 2). As previously mentioned, the water to intertidal-vegetated change was largely due to increases in emergent marsh and mangrove along the back-barrier side of the Chandeleur Island.

\section{Future Efforts}

While the habitat mapping framework used in this effort includes approaches that help reduce the subjectivity and enhance repeatability by using relative topography, elevation uncertainty, and probabilistic rasters in the mapping process, some areas could be improved upon in future efforts. First, while habitat maps provide important snapshots of habitat coverage and are a critical component of monitoring barrier islands and gulf shorelines, targeted multitemporal analyses on barrier islands, such as those used by Zinnert and others (2011, 2016), may help capture and provide more information on the dynamic nature of these systems. Periodic assessments with orthophotography, such as the ones used in this study, only provide a single snapshot of water level, whereas multitemporal analyses can capture a wider range of water levels over a specified time period, which could help minimize issues associated with false change in intertidal areas as noted for this study. In addition to providing more information concerning habitat dynamics, multitemporal satellite analyses could also help enhance the approaches related to elevation uncertainty used in this study. For example, the approach to address elevation uncertainty by using Monte Carlo simulations applies the relative error for vegetated areas regardless of vegetative cover. Yet, multitemporal satellite analyses would allow for a more targeted application of relative error by using a map of deterministic or fractional vegetation cover produced during the time of lidar data acquisition. Collectively, periodic maps and multitemporal analyses could provide information that is critical for adaptive management of these coastal environments by using an approach similar to that of Dalyander and others (2016).

Second, for this current effort, the mapping framework was rerun to completely remap areas for both years. Satellitebased land use/land cover mapping efforts, such as the USGS National Land Cover Database, use change analyses to target areas that changed since the last mapping effort and then focus the mapping effort on the changed areas (Homer and others, 2015). This process can be difficult with orthophotography because of different camera calibrations and settings; however, as a first pass, coarser satellite imagery (for example, 10-m Sentinel-2 satellite imagery) could be used to identify changed areas. These data could be paired with morphological changes in lidar data by using a process similar to the one used by Liu and others (2010). Collectively, these steps could help increase habitat mapping efficiency and reduce false change detection based on subjective differences or omission errors between maps.

Third, we expect that lidar data acquisition will become more frequent in the future. Over time, technological advancements may allow for more regular topographic data collection via earth-orbiting satellites (Patterson and others, 2019). If freely available, these data may enhance coastal habitat mapping analyses by advancing the understanding of topographic changes, and, similar to multitemporal analyses, by minimizing issues with water level variation between periodic habitat maps.

Fourth, as more data are added to the time series, the persistence of changes should also be factored into change analyses by using approaches similar to one developed by Pontius and others (2004).

Fifth, the habitat reporting tool produced for this effort could be enhanced to move beyond reach-specific reporting to custom reporting for user-defined areas (that is, custom polygons or polygons developed by using mapping tools in the web mapping interface).

Finally, the previous BICM habitat maps (that is, 1996/1998, 2001, 2004, and 2005) could be vectorized and analyzed for change with these new habitat data. 


\section{Summary}

In 2005, Louisiana's Coastal Protection and Restoration Authority, in partnership with the University of New Orleans and the U.S. Geological Survey, developed the Barrier Island Comprehensive Monitoring (BICM) Program to monitor and assess changes along the Louisiana Gulf of Mexico shoreline. This report covers the second phase of the BICM habitat analyses. This effort built on the initial BICM habitat mapping efforts, which developed habitat and habitat change maps for 1996/1998, 2001, 2004, and 2005. The overall objectives of the study described in this report were to (1) map habitats for 2008 and 2015-16 for BICM coastal reaches and (2) map habitat change between these two time periods. For the current study, a new detailed 15-class habitat scheme was developed from the original BICM scheme. The new habitat scheme included additional classes developed to delineate various dune habitats, to distinguish between marsh and mangrove, and to distinguish between beach and unvegetated barrier flat habitats. These habitat data were developed by using a geographic object-based image analysis habitat mapping framework that was previously applied to map barrier island habitats on Dauphin Island, Alabama. This approach reduces the subjectivity and enhances the repeatability of habitat delineation by using relative topography and elevation uncertainty.

For the entire BICM region, the area experiencing a change in a land/water category (that is, land gain or land loss) was 3.4 percent, of which, 59.2 percent was land gain and 40.8 percent was land loss. The areal coverages of meadow, mangrove, scrub/shrub, and vegetated dune increased from 2008 to 2015-16, whereas the areal coverages of beach, grassland, and intertidal decreased during this period. The decrease in intertidal was largely due to differing water levels in the orthophotography between 2008 and 2015-16. Regional analyses of habitat coverage and habitat change captured both the dynamic nature of these systems and the effects of restoration efforts, most notably in the Late Lafourche Delta, Modern Delta, and Chandeleur Islands regions. In the Modern Delta region, there was a marked increase in unvegetated flat, meadow, mangrove, scrub/shrub, beach, unvegetated dune, and vegetated dune. As a result, this region experienced the highest percent change for land/water classes (6.6 percent) with land gain accounting for much of this change (70.8 percent). In contrast, the Acadiana Bays region had the highest relative percent loss for all regions. The Acadiana Bays region had a percent change for land/water classes of 2.8 percent, of which, 79.7 percent was land loss.

Natural resource managers can use the results of these mapping efforts to provide insights into the response of these systems to storms and restoration efforts. Further research could explore the use of a multitemporal approach that could provide valuable monitoring information, especially related to informing adaptive management of these systems, between detailed BICM habitat mapping efforts.

\section{References Cited}

Barbier, E.B., Hacker, S.D., Kennedy, C., Koch, E.W., Stier, A.C., and Silliman, B.R., 2011, The value of estuarine and coastal ecosystem services: Ecological Monographs, v. 81, no. 2, p. 169-193. [Also available at https://doi.org/ 10.1890/10-1510.1.]

Blaschke, T., Hay, G.J., Kelly, M., Lang, S., Hofmann, P., Addink, E., Queiroz Feitosa, R., van der Meer, F., van der Werff, H., van Coillie, F., and Tiede, D., 2014, Geographic Object-Based Image Analysis - Towards a new paradigm: ISPRS Journal of Photogrammetry and Remote Sensing, v. 87, p. 180-191. [Also available at https://doi.org/10.1016/ j.isprsjprs.2013.09.014.]

Brantley, S.T., Bissett, S.N., Young, D.R., Wolner, C.W.V., and Moore, L.J., 2014, Barrier island morphology and sediment characteristics affect the recovery of dune building grasses following storm-induced overwash: PLoS One, v. 9, no. 8, art. e104747. [Also available at https://doi.org/10.1371/ journal.pone.0104747.]

Brownett, J.M., and Mills, R.S., 2017, The development and application of remote sensing to monitor sand dune habitats: Journal of Coastal Conservation, v. 21, no. 5, p. 643-656. [Also available at https://doi.org/10.1007/s11852017-0504-X.]

Buffington, K.J., Dugger, B.D., Thorne, K.M., and Takekawa, J.Y., 2016, Statistical correction of lidar-derived digital elevation models with multispectral airborne imagery in tidal marshes: Remote Sensing of Environment, v. 186, p. 616-625. [Also available at https://doi.org/10.1016/ j.rse.2016.09.020.]

Byrnes, M.R., Berlinghoff, J.L., Griffee, S.F., and Lee, D.M., 2018, Louisiana Barrier Island Comprehensive Monitoring Program (BICM)—Phase 2-Updated Shoreline Compilation and Change Assessment, 1880s to 2015: Mashpee, Mass., Applied Coastal Research and Engineering, 46 p.

Campbell, A., Wang, Y., Christiano, M., and Stevens, S., 2017, Salt marsh monitoring in Jamaica Bay, New York from 2003 to 2013 - A decade of change from restoration to Hurricane Sandy: Remote Sensing, v. 9, no. 2, art. 20. [Also available at https://doi.org/10.3390/rs9020131.]

Coastal Protection and Restoration Authority, 2017, Louisiana's Comprehensive Master Plan for a Sustainable Coast: Coastal Protection and Restoration Authority, 171 p., accessed December 16, 2019, at http://coastal.la.gov/wpcontent/uploads/2017/04/2017-Coastal-Master-Plan_WebSingle-Page_CFinal-with-Effective-Date-06092017.pdf. 
Cohen, J., 1960, A coefficient of agreement for nominal scales: Educational and Psychological Measurement, v. 20, no. 1, p. 37-46, accessed November 1, 2019, at https://doi.org/ $10.1177 / 001316446002000104$.

Congalton, R.G., and Green, K., 2009, Assessing the accuracy of remotely sensed data principles and practices ( $2 \mathrm{~d}$ ed.): Boca Raton, Fla., CRC Press, 183 p.

Couvillion, B.R., Beck, Holly, Schoolmaster, Donald, and Fischer, Michelle, 2017, Land area change in coastal Louisiana (1932 to 2016): U.S. Geological Survey Scientific Investigations Map 3381, 16 p. pamphlet, accessed October 21, 2019, at https://doi.org/10.3133/sim3381.

Cowardin, L.M., Carter, V., Golet, F.C., and LaRoe, E.T., 1979, Classification of wetlands and deepwater habitats of the United States: Washington, D.C., U.S. Department of the Interior, Fish and Wildlife Service, Report FWS/ OBS-79/31, p. 131.

Dalyander, P.S., Meyers, M.B., Mattsson, B., Steyer, G., Godsey, E., McDonald, J., Byrnes, M.R., and Ford, M., 2016, Use of structured decision-making to explicitly incorporate environmental process understanding in management of coastal restoration projects - Case study on barrier islands of the northern Gulf of Mexico: Journal of Environmental Management, v. 183, p. 497-509. [Also available at https://doi.org/10.1016/j.jenvman.2016.08.078.]

De Reu, J., Bourgeois, J., Bats, M., Zwertvaegher, A., Gelorini, V., De Smedt, P., Chu, W., Antrop, M., De Maeyer, P., Finke, P., Van Meirvenne, M., Verniers, J., and Crombé, P., 2013, Application of the topographic position index to heterogeneous landscapes: Geomorphology, v. 186, p. 39-49. [Also available at https://doi.org/10.1016/ j.geomorph.2012.12.015.]

Dronova, I., 2015, Object-based image analysis in wetland research-A review: Remote Sensing, v. 7, no. 5, p. 6380-6413. [Also available at https://doi.org/10.3390/ rs70506380.]

Enwright, N.M., Borchert, S.M., Day, R.H., Feher, L.C., Osland, M.J., Wang, L., and Wang, H., 2017, Barrier island habitat map and vegetation survey-Dauphin Island, Alabama, 2015: U.S. Geological Survey Open-File Report 2017-1083, 17 p., accessed September 5, 2018, at https://doi.org/10.3133/ofr20171083.

Enwright, N.M., SooHoo, W.M., Dugas, J.L., Lee, D.M., and Borrok, P.S., 2018a, Louisiana Barrier Island Comprehensive Monitoring Program-Habitat mapping: U.S. Geological Survey data release, accessed October 25, 2019, at https://doi.org/10.5066/F7XP7440.
Enwright, N.M., Wang, L., Borchert, S.M., Day, R.H., Feher, L.C., and Osland, M.J., 2018b, The impact of lidar elevation uncertainty on mapping intertidal habitats on barrier islands: Remote Sensing, v. 10, no. 1, p. 1-18.

Enwright, N.M., Wang, L., Borchert, S.M., Day, R.H., Feher, L.C., and Osland, M.J., 2019, Advancing barrier island habitat mapping using landscape position information: Progress in Physical Geography: Earth and Environment, v. 43, no. 3, p. 425-450. [Also available at https://doi.org/ 10.1177/0309133319839922.]

Feagin, R.A., Smith, W.K., Psuty, N.P., Young, D.R., Martínez, L.M., Carter, G.A., Lucas, K.L., Gibeaut, J.C., Gemma, J.N., and Koske, R.E., 2010, Barrier islands-Coupling anthropogenic stability with ecological sustainability: Journal of Coastal Research, v. 26, p. 987-992. [Also available at https://doi.org/10.2112/09-1185.1.]

Fearnley, S., Brien, L., Martinez, L., Miner, M., Kulp, M., and Penland, S., 2009, Chenier Plain, South-Central Louisiana, and Chandeleur Islands, Habitat mapping and change analysis 1996 to 2005, Part 1-Methods for habitat mapping and change analysis 1996 to 2005-Louisiana Barrier Island Comprehensive Monitoring Program (BICM) 5: New Orleans, University of New Orleans, Pontchartrain Institute for Environmental Sciences, 11 p.

FitzGerald, D., Georgiou, I., Kulp, M., and Miner, M., 2015, Chandeleur Islands - A post-berm analysis and island renourishment plan: New Orleans, University of New Orleans, 47 p., accessed October 31, 2019, at http://www.mississippiriverdelta.org/files/2015/11/ Chandeleur-Isl-Post-berm-Rpt-UNO_Apr_27_2015v3 withApendix-FINAL.pdf.

Gao, J., Chen, H., Zhang, Y., and Zha, Y., 2004, Knowledgebased approaches to accurate mapping of mangroves from satellite data: Photogrammetric Engineering and Remote Sensing, v. 70, no. 11, p. 1241-1248. [Also available at https://doi.org/10.14358/PERS.70.11.1241.]

Halls, J.N., Frishman, M.A., and Hawkes, S.C., 2018, An automated model to classify barrier island geomorphology using lidar data and change analysis (1998-2014): Remote Sensing, v. 10, no. 7, p. 1109. [Also available at https://doi.org/10.3390/rs10071109.]

Hantson, W., Kooistra, L., and Slim, P.A., 2012, Mapping invasive woody species in coastal dunes in the Netherlands-A remote sensing approach using LIDAR and high-resolution aerial photographs: Applied Vegetation Science, v. 15, no. 4, p. 536-547. [Also available at https://doi.org/10.1111/j.1654-109X.2012.01194.x.]

Heidemann, H.K., 2018, Lidar base specification (ver. 1.3, February 2018): U.S. Geological Survey Techniques and Methods, book 11, chap. B4, 101 p., accessed October 23, 2019, at https://doi.org/10.3133/tm11b4. 
Heumann, B.W., 2011, An object-based classification of mangroves using a hybrid decision tree-Support vector machine approach: Remote Sensing, v. 3, no. 11, p. 2440-2460. [Also available at https://doi.org/10.3390/ rs3112440.]

Homer, C.G., Dewitz, J.A., Yang, L., Jin, S., Danielson, P., Xian, G., Coulston, J., Herold, N.D., Wickham, J.D., and Megown, K., 2015, Completion of the 2011 National Land Cover Database for the conterminous United StatesRepresenting a decade of land cover change information: Photogrammetric Engineering and Remote Sensing, v. 81, no. 5 , p. 345-354.

Hunter, G.J., and Goodchild, M.F., 1995, Dealing with error in spatial databases - A simple case study: Photogrammetric Engineering and Remote Sensing, v. 61, p. 529-537.

Jeter, G.W., Jr., and Carter, G.A., 2015, Habitat change on Horn Island, Mississippi, 1940-2010, determined from textural features in panchromatic vertical orthophotography: Geocarto International, v. 31, no. 9, p. 1-10.

Kindinger, J.L., Buster, N.A., Flocks, J.G., Bernier, J.C., and Kulp, M.A., 2013, Louisiana Barrier Island Comprehensive Monitoring (BICM) program summary report—Data and analyses 2006 through 2010: U.S. Geological Survey OpenFile Report 2013-1083, 86 p., accessed April 3, 2017, at https://pubs.usgs.gov/of/2013/1083/.

Lea, C., and Curtis, A.C., 2010, Thematic accuracy assessment procedures, National Park Service Vegetation Inventory, version 2.0: National Park Service, Natural Resource Report NPS/2010/NRR-2010/204, 116 p.

Leatherman, S.P., 1979, Barrier island handbook: National Park Service, Cooperative Research Unit, The Environmental Institute, University of Massachusetts at Amherst.

Liu, H., Sherman, D., and Gu, S., 2007, Automated extraction of shorelines from airborne light detection and ranging data and accuracy assessment based on Monte Carlo simulation: Journal of Coastal Research, v. 236, p. 1359-1369. [Also available at https://doi.org/10.2112/05-0580.1.]

Liu, H., Wang, L., Sherman, D., Gao, Y., and Wu, Q., 2010, An object-based conceptual framework and computational method for representing and analyzing coastal morphological changes: International Journal of Geographical Information Science, v. 24, no. 7, p. 1015-1041. [Also available at https://doi.org/10.1080/13658810903270569.]

Lu, D., and Weng, G., 2007, A survey of image classification methods and techniques for improving classification performance: International Journal of Remote Sensing, v. 28 , no. 5, p. 823-870. [Also available at https://doi.org/ $10.1080 / 01431160600746456$.
Lucas, K.L., and Carter, G.A., 2010, Decadal changes in habitat-type coverage on Horn Island, Mississippi, U.S.A: Journal of Coastal Research, v. 26, p. 1142-1148. [Also available at https://doi.org/10.2112/JCOASTRES-D-0900018.1.]

Lucas, K.L., and Carter, G.A., 2013, Change in distribution and composition of vegetated habitats on Horn Island, Mississippi, northern Gulf of Mexico, in the initial five years following Hurricane Katrina: Geomorphology, v. 199, no. 1, p. 129-137. [Also available at https://doi.org/10.1016/ j.geomorph.2012.11.010.]

McBride, R.A., Anderson, J.B., Buynevich, I.V., Cleary, W., Fenster, M.S., FitzGerald, D.M., Harris, M.S., Hein, C.J., Klein, A.H.F., Liu, B., de Menezes, J.T., Pejrup, M., Riggs, S.R., Short, A.D., Stone, G.W., Wallace, D.J., and Wang, P., 2013, Morphodynamics of barrier systems-A synthesis, in Sherman, D.J., ed., Treatise on geomorphology, Coastal Geomorphology: San Diego, Calif., Academic Press, p. 166-244. [Also available at https://doi.org/10.1016/ B978-0-12-374739-6.00279-7.]

McCarthy, M.J., and Halls, J.N., 2014, Habitat mapping and change assessment of coastal environments-An examination of WorldView-2, QuickBird, and IKONOS satellite orthophotography and airborne LiDAR for mapping barrier island habitats: ISPRS International Journal of Geo-Information, v. 3, no. 1, p. 297-325. [Also available at https://doi.org/10.3390/ijgi3010297.]

Medeiros, S., Hagen, S., Weishampel, J., and Angelo, J., 2015, Adjusting lidar-derived digital terrain models in coastal marshes based on estimated aboveground biomass density: Remote Sensing, v. 7, no. 4, p. 3507-3525. [Also available at https://doi.org/10.3390/rs70403507.]

Myint, S.W., Gober, P., Brazel, A., Grossman-Clarke, S., and Weng, Q., 2011, Per-pixel vs. object-based classification of urban land cover extraction using high spatial resolution imagery: Remote Sensing of Environment, v. 115, no. 5, p. 1145-1161. [Also available at https://doi.org/10.1016/ j.rse.2010.12.017.]

National Oceanic and Atmospheric Administration [NOAA], 2016a, Extreme water levels, 8770570 Sabine Pass North, TX, accessed October 10, 2016, at https://tidesandcurrents.noaa.gov/est/est_station.shtml? stnid $=8770570$.

National Oceanic and Atmospheric Administration [NOAA], 2016b, Extreme water levels, 8761724 Grand Isle, LA, accessed October 10, 2016, at https://tidesandcurrents.noaa.gov/est/est_station.shtml? stnid $=8761724$.

National Oceanic and Atmospheric Administration [NOAA], 2019a, Historical hurricane tracks, accessed October 25, 2019, at https://coast.noaa.gov/hurricanes. 
National Oceanic and Atmospheric Administration [NOAA], 2019b, Relative sea level trend, 8761724 Grand Isle, Louisiana, accessed October 25, 2019, at https://tidesandcurrents.noaa.gov/sltrends/sltrends_ station.shtml?id=8761724.

O'Neil-Dunne, J., MacFaden, S., and Royar, A., 2014, A versatile, production-oriented approach to high-resolution treecanopy mapping in urban and suburban landscapes using GEOBIA and data fusion: Remote Sensing, v. 6, no. 12, p. 12837-12865. [Also available at https://doi.org/10.3390/ rs61212837.]

Osland, M.J., Day, R.H., Hall, C.T., Brumfield, M.D., Dugas, J.L., and Jones, W.R., 2017, Mangrove expansion and contraction at a poleward range limit - Climate extremes and land-ocean temperature gradients: Ecology, v. 98, no. 1, p. 125-137. [Also available at https://doi.org/10.1002/ ecy.1625.]

Osland, M.J., Enwright, N., Day, R.H., and Doyle, T.W., 2013, climate change and coastal wetland foundation species - Salt marshes vs. mangrove forests in the southeastern United States: Global Change Biology, v. 19, no. 5, p. 1482-1494. [Also available at https://doi.org/10.1111/ gcb.12126.]

Parker, B.B., 2003, The difficulties in measuring a consistently defined shoreline- The problem of vertical referencing: Journal of Coastal Research, v. 38, no. Special Issue, p. 44-56.

Patterson, P.L., Healey, S.P., Ståhl, G., Saarela, S., Holm, S., Andersen, H.-E., Dubayah, R.O., Duncanson, L., Hancock, S., Armston, J., Kellner, J.R., Cohen, W.B., and Yang, Z., 2019, Statistical properties of hybrid estimators proposed for GEDI-NASA's global ecosystem dynamics investigation: Environmental Research Letters, v. 14, no. 6, art. 065007. [Also available at https://doi.org/10.1088/17489326/ab18df.]

Penland, S., Boyd, R., and Suter, J.R., 1988, Transgressive depositional systems of the Mississippi Delta plain-A model for barrier shoreline and shelf sand development: Journal of Sedimentary Research, v. 58, no. 6, p. 932-949.

Penland, S., and Suter, J.R., 1989, The geomorphology of the Mississippi River chenier plain: Marine Geology, v. 90, no. 4, p. 231-258. [Also available at https://doi.org/10.1016/ 0025-3227(89)90127-8.]

Pilkey, O.H., and Cooper, J.A.G., 2014, The last beach: Durham, North Carolina, Duke University Press Books, p. 256. [Also available at https://doi.org/10.1215/ 9780822375944.]
Pontius, R.G., Jr., and Millones, M., 2011, Death to KappaBirth of quantity disagreement and allocation disagreement for accuracy assessment: International Journal of Remote Sensing, v. 32, no. 15, p. 4407-4429. [Also available at https://doi.org/10.1080/01431161.2011.552923.]

Pontius, R.G., Jr., Shusas, E., and McEachern, M., 2004, Detecting important categorical land changes while accounting for persistence: Agriculture, Ecosystems \& Environment, v. 101, no. 2-3, p. 251-268. [Also available at https://doi.org/10.1016/j.agee.2003.09.008.]

Psuty, N.P., 1989, An application of science to management problems in dunes along the Atlantic coast of the USA: Proceedings of the Royal Society of Edinburgh, Scotland, B96, p. 289-307.

Rouse, J.W., Haas, R.H., Schell, J.A., and Deering, D.W., 1974, Monitoring vegetation systems in the Great Plains with ERTS, in Freden, S.C., Mercanti, E.P., and Becker, M., Third Earth Resources Technology Satellite-1 Symposium, Volume I: Technical Presentations, NASA SP-351: Washington, D.C., NASA, p. 309-317.

Sallenger, A.H., Jr., 2000, Storm impact scale for barrier islands: Journal of Coastal Research, v. 16, no. 3, p. $890-895$.

Stehman, S.V., and Foody, G.M., 2019, Key issues in rigorous accuracy assessment of land cover products: Remote Sensing of Environment, v. 231, art. 111199. [Also available at https://doi.org/10.1016/j.rse.2019.05.018.]

Sturdivant, E.J., Lentz, E.E., Thieler, E.R., Farris, A.S., Weber, K.M., Remsen, D.P., Miner, S., and Henderson, R.E., 2017, UAS-SfM for coastal research-Geomorphic feature extraction and land cover classification from high-resolution elevation and optical orthophotography: Remote Sensing, v. 9, no. 10, art. 1020. [Also available at https://doi.org/ 10.3390/rs9101020.]

Sweet, W.V., Kopp, R.E., Weaver, C.P., Obeysekera, J., Horton, R.M., Thieler, E.R., and Zervas, C., 2017, Global and regional sea level rise scenarios for the United States: NOAA Technical Report NOS CO-OPS 083, 56 p., accessed October 21, 2019, at https://tidesandcurrents.noaa.gov/ publications/techrpt83_Global_and_Regional_SLR_ Scenarios_for_the_US_final.pdf.

Timm, B.C., and McGarigal, K., 2012, Fine-scale remotely sensed cover mapping of coastal dune and salt marsh ecosystems at Cape Cod National Seashore using Random Forests: Remote Sensing of Environment, v. 127, no. 1, p. 106-117. [Also available at https://doi.org/10.1016/ j.rse.2012.08.033.]

Trimble, 2016, Trimble eCognition Developer, version 9.2 user guide: Munich, Germany, Trimble Germany $\mathrm{GmbH}, 265 \mathrm{p}$. 
Walters, D.C., and Kirwan, M.L., 2016, Optimal hurricane overwash thickness for maximizing marsh resilience to sea level rise: Ecology and Evolution, v. 6, no. 9, p. 2948-2956. [Also available at https://doi.org/10.1002/ece3.2024.]

Wechsler, S.P., and Kroll, C.N., 2006, Quantifying DEM uncertainty and its effect on topographic parameters: Photogrammetric Engineering and Remote Sensing, v. 72, no. 9, p. 1081-1090. [Also available at https://doi.org/ 10.14358/PERS.72.9.1081.]

Weiss, A.D., 2001, Topographic position and landforms analysis: ESRI Users Conference, San Diego, Calif., accessed September 19, 2016, at http://www.jennessent.com/ downloads/tpi-poster-tnc_18x22.pdf.

Wernette, P., Houser, C., and Bishop, M.P., 2016, An automated approach for extracting Barrier Island morphology from digital elevation models: Geomorphology, v. 262, p. 1-7. [Also available at https://doi.org/10.1016/ j.geomorph.2016.02.024.]

Westphal, K., 2018, Louisiana Barrier Island Comprehensive Monitoring Program (BICM) Phase 2-2017 Oblique aerial photo assessment of the Louisiana Barrier Shoreline, 76 p., accessed December 16, 2019, at https://cims.coastal.louisiana.gov/DocLibrary/ FileDownload.aspx?Root=0\&id=23143.

Woodcock, C.E., and Gopal, S., 2000, Fuzzy set theory and thematic maps - Accuracy assessment and area estimation: International Journal of Geographical Information Science, v. 14, no. 2, p. 153-172. [Also available at https://doi.org/ 10.1080/136588100240895.]

Ye, S., Pontius, R.G., Jr., and Rakshit, R., 2018, A review of accuracy assessment for object-based image analysisFrom per-pixel to per-polygon approaches: ISPRS Journal of Photogrammetry and Remote Sensing, v. 141, p. 137-147. [Also available at https://doi.org/10.1016/ j.isprsjprs.2018.04.002.]

Zervas, C., 2013, Extreme water levels of the United States 1893-2010: National Oceanic and Atmospheric Administration, NOAA Technical Report NOS CO-OPS 067, $200 \mathrm{p}$.

Zhou, W., Troy, A., and Grove, M., 2008, Object-based land cover classification and change analysis in the Baltimore metropolitan area using multitemporal high resolution remote sensing data: Sensors (Basel), v. 8, no. 3, p. 1613-1636. [Also available at https://doi.org/10.3390/ s8031613.]
Zinnert, J.C., Shiflett, S.A., Via, S., Bissett, S., Dows, B., Manley, P., and Young, D.R., 2016, Spatial-temporal dynamics in barrier island upland vegetation-The overlooked coastal landscape: Ecosystems (New York, N.Y.), v. 19, no. 4, p. 685-697. [Also available at https://doi.org/ 10.1007/s10021-016-9961-6.]

Zinnert, J.C., Shiflett, S.A., Vick, J.K., and Young, D.R., 2011, Woody vegetative cover dynamics in response to recent climate change on an Atlantic coast barrier island-A remote sensing approach: Geocarto International, v. 26, no. 8, p. 595-612. [Also available at https://doi.org/10.1080/ 10106049.2011.621031.]
For more information about this publication, contact Director, Wetland and Aquatic Research Center U.S. Geological Survey 700 Cajundome Blvd. Lafayette, LA 70506-3152

For additional information, visit https://www.usgs.gov/centers/wetland-and-aquaticresearch-center-warc

Publishing support provided by Lafayette Publishing Service Center 
Appendix 1 


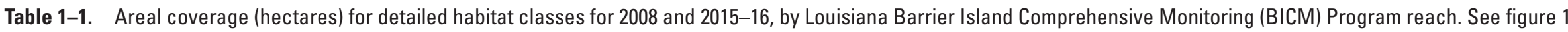
for reach location and name.

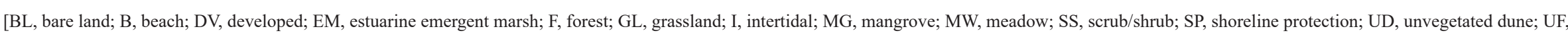
unvegetated flat; $\mathrm{VD}$, vegetated dune; W, water; RT, region total; --, not applicable]

\begin{tabular}{|c|c|c|c|c|c|c|c|c|c|c|c|c|c|c|c|c|c|}
\hline Reach & Date & BL & B & DV & EM & $\mathbf{F}$ & GL & $\mathbf{I}$ & MG & MW & SS & SP & UD & UF & VD & $\mathbf{w}$ & Total \\
\hline \multicolumn{18}{|c|}{ West Chenier Plain region } \\
\hline \multirow[t]{2}{*}{1} & 2008 & 5.62 & 112.80 & 209.84 & $3,909.17$ & 11.46 & 609.23 & 164.47 & 0.00 & 118.78 & 201.13 & 1.13 & 40.54 & 23.19 & 35.20 & $1,467.92$ & $6,910.48$ \\
\hline & 2015 & 3.55 & 30.55 & 212.54 & $4,160.80$ & 20.31 & 550.49 & 116.47 & 0.00 & 144.42 & 210.94 & 0.96 & 22.68 & 26.36 & 104.34 & $1,306.08$ & $6,910.49$ \\
\hline \multirow[t]{2}{*}{2} & 2008 & 0.40 & 49.58 & 72.87 & $2,885.15$ & 0.88 & 274.06 & 91.43 & 0.00 & 5.62 & 60.56 & 3.39 & 14.45 & 47.04 & 6.26 & $1,157.03$ & $4,668.72$ \\
\hline & 2015 & 0.00 & 18.23 & 77.95 & $2,981.56$ & 4.60 & 262.03 & 28.92 & 0.00 & 25.42 & 105.26 & 1.94 & 4.08 & 8.16 & 40.60 & $1,109.98$ & $4,668.73$ \\
\hline \multirow[t]{2}{*}{3} & 2008 & 0.85 & 31.32 & 49.43 & $1,183.01$ & 4.78 & 102.79 & 26.12 & 0.00 & 44.09 & 10.33 & 0.84 & 14.22 & 26.86 & 14.59 & $2,018.93$ & $3,528.16$ \\
\hline & 2015 & 0.20 & 15.57 & 61.74 & $1,371.34$ & 3.89 & 80.09 & 15.45 & 0.00 & 53.42 & 36.98 & 0.73 & 18.88 & 45.95 & 26.78 & $1,797.13$ & $3,528.15$ \\
\hline \multirow[t]{2}{*}{4} & 2008 & 7.27 & 35.78 & 218.77 & $3,857.04$ & 64.61 & 814.43 & 162.47 & 0.00 & 75.49 & 218.13 & 0.78 & 77.10 & 51.58 & 63.05 & $1,445.75$ & $7,092.25$ \\
\hline & 2015 & 0.00 & 24.26 & 253.96 & $3,935.72$ & 38.22 & 689.44 & 43.89 & 0.00 & 155.82 & 346.94 & 0.85 & 37.49 & 26.14 & 114.44 & $1,425.09$ & $7,092.26$ \\
\hline \multirow[t]{2}{*}{5} & 2008 & 0.35 & 13.34 & 1.50 & $1,699.24$ & 1.44 & 58.16 & 164.13 & 0.00 & 38.89 & 18.00 & 0.51 & 23.33 & 20.32 & 0.77 & $1,370.88$ & $3,410.86$ \\
\hline & 2015 & 0.07 & 8.64 & 1.93 & $1,734.48$ & 1.31 & 44.39 & 31.14 & 0.00 & 30.69 & 50.70 & 0.55 & 4.18 & 7.01 & 14.34 & $1,481.44$ & $3,410.87$ \\
\hline \multirow[t]{2}{*}{ RT } & 2008 & 14.49 & 242.82 & 552.41 & $13,533.61$ & 83.17 & $1,858.67$ & 608.62 & 0.00 & 282.87 & 508.15 & 6.65 & 169.64 & 168.99 & 119.87 & $7,460.51$ & $25,610.47$ \\
\hline & 2015 & 3.82 & 97.25 & 608.12 & $14,183.90$ & 68.33 & $1,626.44$ & 235.87 & 0.00 & 409.77 & 750.82 & 5.03 & 87.31 & 113.62 & 300.50 & $7,119.72$ & $25,610.50$ \\
\hline \multicolumn{18}{|c|}{ East Chenier Plain region } \\
\hline \multirow[t]{2}{*}{6} & 2008 & 1.17 & 106.70 & 5.38 & $11,523.53$ & 0.00 & 135.59 & 229.39 & 0.00 & 85.94 & 89.07 & 0.41 & 18.31 & 156.86 & 0.31 & $10,079.32$ & $22,431.98$ \\
\hline & 2015 & 16.00 & 21.53 & 4.87 & $11,325.36$ & 0.03 & 63.90 & 120.36 & 0.00 & 81.48 & 170.43 & 0.45 & 14.11 & 126.58 & 5.21 & $10,481.67$ & $22,431.98$ \\
\hline \multirow[t]{2}{*}{7} & 2008 & 0.51 & 8.45 & 0.14 & $3,111.34$ & 6.88 & 21.05 & 28.37 & 0.00 & 38.99 & 10.52 & 0.00 & 7.42 & 83.39 & 0.05 & $1,652.40$ & $4,969.51$ \\
\hline & 2015 & 6.36 & 3.18 & 0.11 & $3,185.11$ & 12.73 & 3.84 & 8.01 & 0.00 & 39.54 & 55.54 & 0.00 & 0.02 & 8.87 & 0.46 & $1,645.76$ & $4,969.53$ \\
\hline \multirow[t]{2}{*}{8} & 2008 & 2.13 & 0.00 & 19.93 & $3,278.14$ & 1.99 & 41.22 & 4.00 & 0.00 & 396.02 & 61.83 & 0.00 & 0.00 & 17.29 & 0.00 & $1,329.00$ & $5,151.55$ \\
\hline & 2015 & 0.07 & 0.08 & 17.64 & $3,410.11$ & 12.51 & 19.29 & 2.11 & 0.00 & 302.41 & 139.98 & 0.26 & 0.00 & 18.84 & 0.00 & $1,228.25$ & $5,151.55$ \\
\hline \multirow[t]{2}{*}{9} & 2008 & 9.60 & 11.21 & 0.64 & $2,150.10$ & 67.22 & 140.33 & 12.87 & 0.00 & 6.16 & 93.99 & 0.26 & 5.43 & 26.24 & 0.19 & $1,078.48$ & $3,602.72$ \\
\hline & 2015 & 0.00 & 2.61 & 0.64 & $2,173.96$ & 93.89 & 76.06 & 7.78 & 0.00 & 12.46 & 205.50 & 0.46 & 7.05 & 11.96 & 3.30 & $1,007.04$ & $3,602.71$ \\
\hline \multirow[t]{2}{*}{10} & 2008 & 0.00 & 6.95 & 0.02 & $2,911.83$ & 43.25 & 33.21 & 7.37 & 0.00 & 16.42 & 36.97 & 0.59 & 12.96 & 13.21 & 5.36 & $1,184.69$ & $4,272.83$ \\
\hline & 2015 & 0.00 & 3.43 & 0.03 & $2,910.96$ & 55.70 & 14.54 & 10.80 & 0.00 & 11.00 & 42.77 & 1.13 & 18.99 & 13.95 & 3.30 & $1,186.25$ & $4,272.85$ \\
\hline \multirow[t]{2}{*}{ RT } & 2008 & 13.41 & 133.31 & 26.11 & $22,974.94$ & 119.34 & 371.40 & 282.00 & 0.00 & 543.53 & 292.38 & 1.26 & 44.12 & 296.99 & 5.91 & $15,323.89$ & $40,428.59$ \\
\hline & 2015 & 22.43 & 30.83 & 23.29 & $23,005.50$ & 174.86 & 177.63 & 149.06 & 0.00 & 446.89 & 614.22 & 2.30 & 40.17 & 180.20 & 12.27 & $15,548.97$ & $40,428.62$ \\
\hline \multicolumn{18}{|c|}{ Acadiana Bays region } \\
\hline \multirow[t]{2}{*}{11} & 2008 & 0.87 & 5.64 & 0.09 & $5,745.33$ & 0.00 & 22.86 & 90.83 & 0.00 & 362.11 & 12.65 & 0.00 & 10.70 & 10.87 & 13.41 & $3,061.88$ & $9,337.24$ \\
\hline & $2015-16$ & 8.29 & 6.82 & 0.15 & $5,525.91$ & 0.01 & 6.65 & 13.81 & 0.00 & 426.56 & 24.58 & 0.00 & 2.15 & 10.30 & 13.90 & $3,298.14$ & $9,337.27$ \\
\hline
\end{tabular}


Table 1-1. Areal coverage (hectares) for detailed habitat classes for 2008 and 2015-16, by Louisiana Barrier Island Comprehensive Monitoring (BICM) Program reach. See figure 1 for reach location and name.-Continued

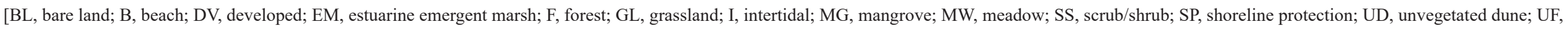
unvegetated flat; VD, vegetated dune; W, water; RT, region total; --, not applicable]

\begin{tabular}{|c|c|c|c|c|c|c|c|c|c|c|c|c|c|c|c|c|c|}
\hline Reach & Date & BL & B & DV & EM & $\mathbf{F}$ & GL & I & MG & MW & SS & SP & UD & UF & VD & $\mathbf{W}$ & Total \\
\hline \multicolumn{18}{|c|}{ Early Lafourche Delta region } \\
\hline \multirow[t]{2}{*}{34} & 2008 & 0.56 & 11.30 & 1.34 & $3,622.43$ & 0.00 & 6.99 & 295.16 & 1.57 & 5.00 & 41.17 & 1.96 & 17.98 & 55.69 & 0.39 & $2,897.39$ & $6,958.93$ \\
\hline & 2016 & 0.00 & 7.53 & 0.82 & $3,645.54$ & 0.00 & 11.68 & 10.39 & 6.59 & 49.31 & 29.78 & 1.96 & 1.55 & 16.94 & 2.61 & $3,174.25$ & $6,958.95$ \\
\hline \multirow[t]{2}{*}{35} & 2008 & 0.00 & 5.27 & 0.68 & $4,604.92$ & 0.00 & 25.08 & 786.01 & 109.17 & 7.46 & 5.77 & 0.32 & 3.67 & 24.06 & 0.00 & $7,455.26$ & $13,027.67$ \\
\hline & 2016 & 0.10 & 2.20 & 0.40 & $4,166.76$ & 0.00 & 3.46 & 21.48 & 339.60 & 4.31 & 28.52 & 0.23 & 0.24 & 15.12 & 0.04 & $8,445.19$ & $13,027.65$ \\
\hline \multirow[t]{2}{*}{36} & 2008 & 0.00 & 4.76 & 0.00 & 2.12 & 0.00 & 0.00 & 45.67 & 1.98 & 2.81 & 0.12 & 1.57 & 1.43 & 5.14 & 4.90 & $2,654.80$ & $2,725.30$ \\
\hline & 2016 & 0.86 & 6.03 & 0.00 & 4.88 & 0.00 & 0.00 & 20.57 & 2.21 & 12.31 & 0.14 & 1.10 & 0.03 & 11.03 & 3.79 & $2,662.35$ & $2,725.30$ \\
\hline \multirow[t]{2}{*}{37} & 2008 & 0.00 & 12.45 & 0.45 & 143.05 & 0.00 & 0.00 & 128.28 & 196.44 & 25.74 & 0.10 & 0.00 & 10.36 & 32.30 & 5.20 & $4,305.75$ & $4,860.12$ \\
\hline & 2016 & 0.00 & 4.03 & 0.43 & 200.91 & 0.00 & 0.00 & 15.83 & 261.18 & 33.01 & 0.00 & 0.28 & 0.00 & 12.83 & 2.54 & $4,329.08$ & $4,860.12$ \\
\hline \multirow[t]{2}{*}{38} & 2008 & 0.84 & 43.63 & 0.08 & 56.51 & 0.00 & 1.00 & 47.46 & 30.65 & 18.49 & 11.06 & 0.00 & 11.98 & 50.73 & 4.38 & $3,208.29$ & $3,485.10$ \\
\hline & 2016 & 0.00 & 3.89 & 0.08 & 17.02 & 0.00 & 0.00 & 15.01 & 64.84 & 60.86 & 17.00 & 0.00 & 0.03 & 7.24 & 24.58 & $3,274.26$ & $3,484.81$ \\
\hline \multirow[t]{2}{*}{39} & 2008 & 0.00 & 18.96 & 0.29 & 6.62 & 0.00 & 0.00 & 22.82 & 0.22 & 17.02 & 0.04 & 0.00 & 15.48 & 31.49 & 6.54 & $2,177.07$ & $2,296.55$ \\
\hline & 2016 & 0.00 & 1.00 & 0.16 & 2.61 & 0.00 & 0.00 & 4.44 & 3.03 & 24.93 & 7.75 & 0.00 & 0.21 & 5.73 & 16.25 & $2,230.42$ & $2,296.53$ \\
\hline \multirow[t]{2}{*}{40} & 2008 & 0.00 & 0.39 & 0.00 & 0.41 & 0.00 & 0.00 & 2.75 & 0.00 & 0.67 & 0.00 & 0.37 & 0.00 & 0.99 & 0.00 & $2,902.04$ & $2,907.62$ \\
\hline & 2016 & 0.00 & 0.57 & 0.30 & 0.00 & 0.00 & 0.00 & 2.04 & 0.00 & 0.00 & 0.00 & 0.24 & 0.00 & 0.00 & 0.00 & $2,904.47$ & $2,907.62$ \\
\hline \multirow[t]{2}{*}{ RT } & 2008 & 1.40 & 96.76 & 2.84 & $8,436.06$ & 0.00 & 33.07 & $1,328.15$ & 340.03 & 77.19 & 58.26 & 4.22 & 60.90 & 200.40 & 21.41 & $25,600.60$ & $36,261.29$ \\
\hline & 2016 & 0.96 & 25.25 & 2.19 & $8,037.72$ & 0.00 & 15.14 & 89.76 & 677.45 & 184.73 & 83.19 & 3.81 & 2.06 & 68.89 & 49.81 & $27,020.02$ & $36,260.98$ \\
\hline \multicolumn{18}{|c|}{ Late Lafourche Delta region } \\
\hline \multirow[t]{2}{*}{41} & 2008 & 0.00 & 34.11 & 1.07 & 81.85 & 0.00 & 0.00 & 113.00 & 42.70 & 78.81 & 68.65 & 0.59 & 31.51 & 23.47 & 17.81 & $7,880.49$ & $8,374.06$ \\
\hline & 2016 & 0.92 & 10.84 & 0.95 & 57.28 & 0.00 & 0.00 & 29.95 & 84.13 & 116.95 & 51.14 & 0.38 & 0.16 & 7.86 & 28.76 & $7,984.76$ & $8,374.08$ \\
\hline \multirow[t]{2}{*}{42} & 2008 & 0.00 & 2.99 & 3.52 & 10.13 & 0.00 & 0.27 & 46.43 & 11.42 & 7.01 & 0.62 & 1.45 & 0.75 & 19.30 & 0.56 & $3,730.37$ & $3,834.82$ \\
\hline & 2016 & 0.00 & 1.49 & 3.58 & 5.78 & 0.00 & 0.00 & 12.04 & 8.32 & 6.45 & 2.15 & 0.13 & 0.01 & 6.49 & 0.14 & $3,788.25$ & $3,834.83$ \\
\hline \multirow[t]{2}{*}{43} & 2008 & 10.98 & 2.96 & 0.22 & 112.76 & 0.00 & 3.54 & 86.23 & 85.07 & 4.08 & 1.20 & 1.61 & 0.22 & 11.89 & 1.64 & $2,090.10$ & $2,412.50$ \\
\hline & 2016 & 7.92 & 3.73 & 0.15 & 62.76 & 0.00 & 8.24 & 24.96 & 177.88 & 11.97 & 1.86 & 1.32 & 0.39 & 102.54 & 0.86 & $2,007.93$ & $2,412.51$ \\
\hline \multirow[t]{2}{*}{44} & 2008 & 4.71 & 58.11 & 189.18 & $1,896.93$ & 0.00 & 65.97 & 314.54 & 360.24 & 16.80 & 49.05 & 3.68 & 14.44 & 175.79 & 15.16 & $5,363.09$ & $8,527.69$ \\
\hline & 2016 & 2.51 & 33.81 & 188.32 & $1,354.55$ & 0.00 & 37.16 & 66.85 & 641.83 & 73.72 & 110.18 & 2.86 & 150.46 & 90.36 & 9.42 & $5,765.61$ & $8,527.64$ \\
\hline \multirow[t]{2}{*}{45} & 2008 & 12.63 & 39.46 & 483.84 & 247.63 & 6.34 & 6.52 & 139.73 & 39.34 & 155.17 & 55.14 & 8.51 & 7.14 & 58.51 & 12.64 & $3,845.80$ & $5,118.40$ \\
\hline & 2016 & 0.23 & 32.59 & 500.46 & 245.09 & 9.78 & 0.22 & 19.10 & 76.97 & 197.39 & 88.76 & 9.17 & 1.54 & 16.74 & 32.23 & $3,888.13$ & $5,118.40$ \\
\hline \multirow[t]{2}{*}{46} & 2008 & 0.15 & 5.35 & 2.40 & 109.91 & 0.00 & 5.36 & 26.38 & 0.83 & 29.70 & 3.66 & 2.10 & 2.60 & 23.44 & 9.35 & $1,924.01$ & $2,145.24$ \\
\hline & 2016 & 0.00 & 5.90 & 1.56 & 88.66 & 0.00 & 2.45 & 9.20 & 23.34 & 48.88 & 8.08 & 1.72 & 0.00 & 5.44 & 7.65 & $1,942.36$ & $2,145.24$ \\
\hline
\end{tabular}




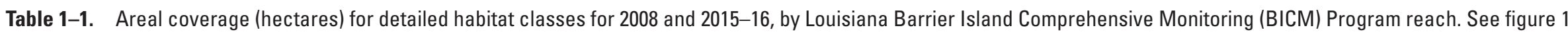
for reach location and name.-Continued

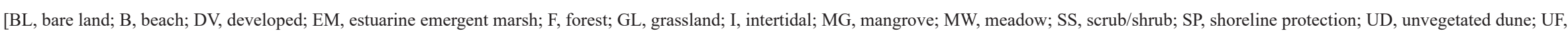
unvegetated flat; $\mathrm{VD}$, vegetated dune; $\mathrm{W}$, water; RT, region total; --, not applicable]

\begin{tabular}{|c|c|c|c|c|c|c|c|c|c|c|c|c|c|c|c|c|c|}
\hline Reach & Date & BL & B & DV & EM & $\mathbf{F}$ & GL & $\mathbf{I}$ & MG & MW & SS & SP & UD & UF & VD & $\mathbf{W}$ & Total \\
\hline \multicolumn{18}{|c|}{ Late Lafourche Delta region-Continued } \\
\hline \multirow[t]{2}{*}{47} & 2008 & 0.00 & 4.32 & 0.00 & 92.70 & 0.00 & 0.00 & 71.66 & 42.76 & 3.35 & 0.00 & 0.00 & 0.14 & 11.39 & 0.19 & $2,147.31$ & $2,373.82$ \\
\hline & 2016 & 0.00 & 3.98 & 0.00 & 138.51 & 0.00 & 1.10 & 15.02 & 35.73 & 23.43 & 3.03 & 0.00 & 0.00 & 32.05 & 0.00 & $2,120.95$ & $2,373.80$ \\
\hline \multirow[t]{2}{*}{ RT } & 2008 & 28.47 & 147.30 & 680.23 & $2,551.91$ & 6.34 & 81.66 & 797.97 & 582.36 & 294.92 & 178.32 & 17.94 & 56.80 & 323.79 & 57.35 & $26,981.17$ & $32,786.53$ \\
\hline & 2016 & 11.58 & 92.34 & 695.02 & $1,952.63$ & 9.78 & 49.17 & 177.12 & $1,048.20$ & 478.79 & 265.20 & 15.58 & 152.56 & 261.48 & 79.06 & $27,497.99$ & $32,786.50$ \\
\hline \multicolumn{18}{|c|}{ Modern Delta region } \\
\hline \multirow[t]{2}{*}{48} & 2008 & 8.83 & 21.70 & 2.49 & 918.64 & 0.00 & 0.89 & 541.83 & 65.46 & 27.35 & 46.15 & 0.11 & 5.84 & 120.59 & 5.11 & $6,320.61$ & $8,085.60$ \\
\hline & 2016 & 5.56 & 18.51 & 2.20 & 738.07 & 0.00 & 0.10 & 27.91 & 110.08 & 159.52 & 59.44 & 0.00 & 1.12 & 117.23 & 30.76 & $6,815.09$ & $8,085.59$ \\
\hline \multirow[t]{2}{*}{49} & 2008 & 0.00 & 9.11 & 0.69 & 486.25 & 0.00 & 0.00 & 176.58 & 4.37 & 18.41 & 0.93 & 1.15 & 1.37 & 23.25 & 0.59 & $9,102.42$ & $9,825.12$ \\
\hline & 2016 & 6.06 & 33.27 & 0.68 & 500.60 & 0.00 & 5.01 & 56.60 & 14.21 & 144.96 & 2.17 & 0.88 & 78.77 & 205.40 & 12.61 & $8,763.89$ & $9,825.11$ \\
\hline \multirow[t]{2}{*}{ RT } & 2008 & 8.83 & 30.81 & 3.18 & $1,404.89$ & 0.00 & 0.89 & 718.41 & 69.83 & 45.76 & 47.08 & 1.26 & 7.21 & 143.84 & 5.70 & $15,423.03$ & $17,910.72$ \\
\hline & 2016 & 11.62 & 51.78 & 2.88 & $1,238.67$ & 0.00 & 5.11 & 84.51 & 124.29 & 304.48 & 61.61 & 0.88 & 79.89 & 322.63 & 43.37 & $15,578.98$ & $17,910.70$ \\
\hline \multicolumn{18}{|c|}{ Chandeleur Islands region } \\
\hline \multirow[t]{2}{*}{59} & 2008 & 0.04 & 0.47 & 0.14 & 1.06 & 0.00 & 0.00 & 53.13 & 1.78 & 1.48 & 0.01 & 0.14 & 0.00 & 3.70 & 0.16 & $5,126.06$ & $5,188.17$ \\
\hline & 2016 & 0.00 & 4.48 & 0.29 & 8.67 & 0.00 & 0.00 & 32.31 & 1.56 & 8.01 & 0.09 & 0.08 & 0.00 & 20.35 & 0.23 & $5,112.08$ & $5,188.15$ \\
\hline \multirow[t]{2}{*}{60} & 2008 & 0.00 & 0.00 & 0.02 & 0.00 & 0.00 & 0.00 & 5.14 & 0.00 & 0.00 & 0.00 & 0.00 & 0.00 & 0.00 & 0.00 & $11,592.51$ & $11,597.67$ \\
\hline & 2016 & 0.00 & 8.45 & 0.01 & 1.89 & 0.00 & 0.00 & 77.31 & 0.00 & 3.13 & 0.00 & 0.00 & 0.00 & 24.47 & 0.00 & $11,482.41$ & $11,597.67$ \\
\hline \multirow[t]{2}{*}{61} & 2008 & 0.00 & 14.10 & 0.03 & 155.48 & 0.00 & 0.00 & 507.23 & 48.23 & 20.75 & 0.04 & 0.00 & 4.01 & 125.41 & 9.78 & $25,460.48$ & $26,345.54$ \\
\hline & 2016 & 0.00 & 49.83 & 0.03 & 283.89 & 0.00 & 0.00 & 333.71 & 85.53 & 57.62 & 2.17 & 0.00 & 2.36 & 256.92 & 15.51 & $25,258.33$ & $26,345.90$ \\
\hline \multirow[t]{2}{*}{ RT } & 2008 & 0.04 & 14.57 & 0.19 & 156.54 & 0.00 & 0.00 & 565.50 & 50.01 & 22.23 & 0.05 & 0.14 & 4.01 & 129.11 & 9.94 & $42,179.05$ & $43,131.38$ \\
\hline & 2016 & 0.00 & 62.76 & 0.33 & 294.45 & 0.00 & 0.00 & 443.33 & 87.09 & 68.76 & 2.26 & 0.08 & 2.36 & 301.74 & 15.74 & $41,852.82$ & $43,131.72$ \\
\hline \multicolumn{18}{|c|}{ BICM region-wide (fig. 1) } \\
\hline-- & 2008 & 67.51 & 671.21 & $1,265.05$ & $54,803.28$ & 208.85 & $2,368.55$ & $4,391.48$ & $1,042.23$ & $1,628.61$ & $1,096.89$ & 31.47 & 353.38 & $1,273.99$ & 233.59 & $136,030.13$ & $205,466.22$ \\
\hline-- & $2015-16$ & 58.70 & 367.03 & $1,331.98$ & $54,238.78$ & 252.98 & $1,880.14$ & $1,193.46$ & $1,937.03$ & $2,319.98$ & $1,801.88$ & 27.68 & 366.50 & $1,258.86$ & 514.65 & $137,916.64$ & $205,466.29$ \\
\hline
\end{tabular}


Table 1-2. Areal coverage (hectares) for general habitat classes for 2008 and 2015-16, by Louisiana Barrier Island Comprehensive Monitoring (BICM) Program reach. See figure 1 for reach location and name.

[BL, bare land; BV, barrier vegetation; B, beach; EW, estuarine vegetated wetland; I, intertidal; RR, rip-rap; ST, structure; W, water; RT, region total]

\begin{tabular}{|c|c|c|c|c|c|c|c|c|c|c|}
\hline Reach & Date & BL & BV & B & EW & $\mathbf{I}$ & $\mathbf{R R}$ & ST & $\mathbf{W}$ & Total \\
\hline \multicolumn{11}{|c|}{ West Chenier Plain region } \\
\hline \multirow[t]{2}{*}{1} & 2008 & 46.16 & 975.80 & 135.99 & $3,909.17$ & 164.47 & 1.13 & 209.84 & $1,467.92$ & $6,910.48$ \\
\hline & 2015 & 26.23 & $1,030.50$ & 56.90 & $4,160.8$ & 116.47 & 0.96 & 212.54 & $1,306.08$ & $6,910.48$ \\
\hline \multirow[t]{2}{*}{2} & 2008 & 14.85 & 347.38 & 96.62 & $2,885.15$ & 91.43 & 3.39 & 72.87 & $1,157.03$ & $4,668.72$ \\
\hline & 2015 & 4.08 & 437.91 & 26.38 & $2,981.56$ & 28.92 & 1.94 & 77.95 & $1,109.98$ & $4,668.72$ \\
\hline \multirow[t]{2}{*}{3} & 2008 & 15.07 & 176.57 & 58.18 & $1,183.01$ & 26.12 & 0.84 & 49.43 & $2,018.93$ & $3,528.15$ \\
\hline & 2015 & 19.08 & 201.16 & 61.52 & $1,371.34$ & 15.45 & 0.73 & 61.74 & $1,797.13$ & $3,528.15$ \\
\hline \multirow[t]{2}{*}{4} & 2008 & 84.37 & $1,235.72$ & 87.36 & $3,857.04$ & 162.47 & 0.78 & 218.77 & $1,445.75$ & $7,092.26$ \\
\hline & 2015 & 37.49 & $1,344.87$ & 50.39 & $3,935.72$ & 43.89 & 0.85 & 253.96 & $1,425.09$ & $7,092.26$ \\
\hline \multirow[t]{2}{*}{5} & 2008 & 23.69 & 117.27 & 33.66 & $1,699.24$ & 164.13 & 0.51 & 1.50 & $1,370.88$ & $3,410.88$ \\
\hline & 2015 & 4.25 & 141.43 & 15.65 & $1,734.48$ & 31.14 & 0.55 & 1.93 & $1,481.44$ & $3,410.87$ \\
\hline \multirow[t]{2}{*}{ RT } & 2008 & 184.14 & $2,852.74$ & 411.81 & $13,533.61$ & 608.62 & 6.65 & 552.41 & $7,460.51$ & $25,610.49$ \\
\hline & 2015 & 91.13 & $3,155.87$ & 210.84 & $14,183.90$ & 235.87 & 5.03 & 608.12 & $7,119.72$ & $25,610.48$ \\
\hline \multicolumn{11}{|c|}{ East Chenier Plain region } \\
\hline \multirow[t]{2}{*}{6} & 2008 & 19.47 & 310.91 & 263.56 & $11,523.53$ & 229.39 & 0.41 & 5.38 & $10,079.32$ & $22,431.97$ \\
\hline & 2015 & 30.11 & 321.06 & 148.10 & $11,325.36$ & 120.36 & 0.45 & 4.87 & $10,481.67$ & $22,431.98$ \\
\hline \multirow[t]{2}{*}{7} & 2008 & 7.93 & 77.50 & 91.84 & $3,111.34$ & 28.37 & 0.00 & 0.14 & $1,652.40$ & $4,969.52$ \\
\hline & 2015 & 6.38 & 112.11 & 12.05 & $3,185.11$ & 8.01 & 0.00 & 0.11 & $1,645.76$ & $4,969.53$ \\
\hline \multirow[t]{2}{*}{8} & 2008 & 2.13 & 501.06 & 17.30 & $3,278.14$ & 4.00 & 0.00 & 19.93 & $1,329.00$ & $5,151.56$ \\
\hline & 2015 & 0.07 & 474.20 & 18.91 & $3,410.11$ & 2.11 & 0.26 & 17.64 & $1,228.25$ & $5,151.55$ \\
\hline \multirow[t]{2}{*}{9} & 2008 & 15.03 & 307.89 & 37.45 & $2,150.10$ & 12.87 & 0.26 & 0.64 & $1,078.48$ & $3,602.72$ \\
\hline & 2015 & 7.05 & 391.22 & 14.57 & $2,173.96$ & 7.78 & 0.46 & 0.64 & $1,007.04$ & $3,602.72$ \\
\hline \multirow[t]{2}{*}{10} & 2008 & 12.96 & 135.22 & 20.16 & $2,911.83$ & 7.37 & 0.59 & 0.02 & $1,184.69$ & $4,272.84$ \\
\hline & 2015 & 18.99 & 127.31 & 17.39 & $2,910.96$ & 10.80 & 1.13 & 0.03 & $1,186.25$ & $4,272.86$ \\
\hline \multirow[t]{2}{*}{ RT } & 2008 & 57.52 & 1332.58 & 430.31 & $22,974.94$ & 282.00 & 1.26 & 26.11 & $15,323.89$ & $40,428.61$ \\
\hline & 2015 & 62.60 & 1425.90 & 211.02 & $23,005.50$ & 149.06 & 2.30 & 23.29 & $15,548.97$ & $40,428.64$ \\
\hline \multicolumn{11}{|c|}{ Acadiana Bays region } \\
\hline \multirow[t]{2}{*}{11} & 2008 & 11.57 & 411.04 & 16.52 & $5,745.33$ & 90.83 & 0.00 & 0.09 & $3,061.88$ & $9,337.26$ \\
\hline & $2015-16$ & 10.44 & 471.70 & 17.12 & $5,525.91$ & 13.81 & 0.00 & 0.15 & $3,298.14$ & $9,337.27$ \\
\hline
\end{tabular}


Table 1-2. Areal coverage (hectares) for general habitat classes for 2008 and 2015-16, by Louisiana Barrier Island Comprehensive Monitoring (BICM)

Program reach. See figure 1 for reach location and name.-Continued

[BL, bare land; BV, barrier vegetation; B, beach; EW, estuarine vegetated wetland; I, intertidal; RR, rip-rap; ST, structure; W, water; RT, region total]

\begin{tabular}{|c|c|c|c|c|c|c|c|c|c|c|}
\hline Reach & Date & BL & BV & B & EW & I & RR & ST & $\mathbf{W}$ & Total \\
\hline \multicolumn{11}{|c|}{ Early Lafourche Delta region } \\
\hline \multirow[t]{2}{*}{34} & 2008 & 18.54 & 53.55 & 66.99 & $3,624.00$ & 295.16 & 1.96 & 1.34 & $2,897.39$ & $6,958.93$ \\
\hline & 2016 & 1.55 & 93.38 & 24.46 & $3,652.13$ & 10.39 & 1.96 & 0.82 & $3,174.25$ & $6,958.94$ \\
\hline \multirow[t]{2}{*}{35} & 2008 & 3.67 & 38.31 & 29.32 & $4,714.09$ & 786.01 & 0.32 & 0.68 & $7,455.26$ & $13,027.66$ \\
\hline & 2016 & 0.35 & 36.34 & 17.32 & $4,506.36$ & 21.48 & 0.23 & 0.40 & $8,445.19$ & $13,027.67$ \\
\hline \multirow[t]{2}{*}{36} & 2008 & 1.43 & 7.83 & 9.90 & 4.10 & 45.68 & 1.57 & 0.00 & $2,654.80$ & $2,725.31$ \\
\hline & 2016 & 0.89 & 16.24 & 17.06 & 7.10 & 20.57 & 1.10 & 0.00 & $2,662.35$ & $2,725.31$ \\
\hline \multirow[t]{2}{*}{37} & 2008 & 10.36 & 31.04 & 44.75 & 339.49 & 128.28 & 0.00 & 0.45 & $4,305.75$ & $4,860.12$ \\
\hline & 2016 & 0.00 & 35.55 & 16.86 & 462.10 & 15.83 & 0.28 & 0.43 & $4,329.08$ & $4,860.13$ \\
\hline \multirow[t]{2}{*}{38} & 2008 & 12.82 & 34.94 & 94.36 & 87.16 & 47.46 & 0.00 & 0.08 & $3,208.29$ & $3,485.11$ \\
\hline & 2016 & 0.32 & 102.44 & 11.15 & 81.85 & 15.01 & 0.00 & 0.08 & $3,274.26$ & $3,485.11$ \\
\hline \multirow[t]{2}{*}{39} & 2008 & 15.48 & 23.59 & 50.45 & 6.84 & 22.82 & 0.00 & 0.29 & $2,177.07$ & $2,296.54$ \\
\hline & 2016 & 0.21 & 48.94 & 6.73 & 5.64 & 4.44 & 0.00 & 0.16 & $2,230.42$ & $2,296.54$ \\
\hline \multirow[t]{2}{*}{40} & 2008 & 0.00 & 0.67 & 1.38 & 0.41 & 2.75 & 0.37 & 0.00 & $2,902.04$ & $2,907.62$ \\
\hline & 2016 & 0.00 & 0.00 & 0.57 & 0.00 & 2.04 & 0.24 & 0.30 & $2,904.47$ & $2,907.62$ \\
\hline \multirow[t]{2}{*}{ RT } & 2008 & 62.30 & 189.93 & 297.15 & $8,776.09$ & $1,328.16$ & 4.22 & 2.84 & $25,600.60$ & $36,261.29$ \\
\hline & 2016 & 3.32 & 332.89 & 94.15 & $8,715.18$ & 89.76 & 3.81 & 2.19 & $27,020.02$ & $36,261.32$ \\
\hline \multicolumn{11}{|c|}{ Late Lafourche Delta region } \\
\hline \multirow[t]{2}{*}{41} & 2008 & 31.51 & 165.26 & 57.58 & 124.56 & 113.00 & 0.59 & 1.07 & $7,880.49$ & $8,374.06$ \\
\hline & 2016 & 1.08 & 79.90 & 18.70 & 258.37 & 29.95 & 0.38 & 0.95 & $7,984.76$ & $8,374.09$ \\
\hline \multirow[t]{2}{*}{42} & 2008 & 0.75 & 8.45 & 22.29 & 21.55 & 46.43 & 1.45 & 3.52 & $3,730.37$ & $3,834.81$ \\
\hline & 2016 & 0.01 & 2.29 & 7.98 & 20.55 & 12.04 & 0.13 & 3.58 & $3,788.25$ & $3,834.83$ \\
\hline \multirow[t]{2}{*}{43} & 2008 & 11.21 & 10.46 & 14.86 & 197.83 & 86.23 & 1.61 & 0.22 & $2,090.10$ & $2,412.52$ \\
\hline & 2016 & 8.32 & 10.96 & 106.26 & 252.62 & 24.96 & 1.32 & 0.15 & $2,007.93$ & $2,412.52$ \\
\hline \multirow[t]{2}{*}{44} & 2008 & 19.15 & 146.92 & 233.89 & $2,257.10$ & 314.54 & 3.68 & 189.18 & $5,363.09$ & $8,527.63$ \\
\hline & 2016 & 152.97 & 156.76 & 124.17 & $2,070.10$ & 66.85 & 2.86 & 188.32 & $5,765.61$ & $8,527.64$ \\
\hline \multirow[t]{2}{*}{45} & 2008 & 19.77 & 235.81 & 97.97 & 286.98 & 139.73 & 8.51 & 483.84 & $3,845.80$ & $5,118.41$ \\
\hline & 2016 & 1.77 & 130.99 & 49.33 & 519.46 & 19.10 & 9.17 & 500.46 & $3,888.13$ & $5,118.41$ \\
\hline \multirow[t]{2}{*}{46} & 2008 & 2.75 & 48.07 & 28.79 & 110.74 & 26.38 & 2.10 & 2.40 & $1,924.01$ & $2,145.24$ \\
\hline & 2016 & 0.00 & 18.18 & 11.34 & 160.88 & 9.20 & 1.72 & 1.56 & $1,942.36$ & $2,145.24$ \\
\hline
\end{tabular}


Table 1-2. Areal coverage (hectares) for general habitat classes for 2008 and 2015-16, by Louisiana Barrier Island Comprehensive Monitoring (BICM) Program reach. See figure 1 for reach location and name.-Continued

[BL, bare land; BV, barrier vegetation; B, beach; EW, estuarine vegetated wetland; I, intertidal; RR, rip-rap; ST, structure; W, water; RT, region total]

\begin{tabular}{|c|c|c|c|c|c|c|c|c|c|c|}
\hline Reach & Date & BL & BV & B & EW & $\mathbf{I}$ & $\mathbf{R R}$ & ST & $\mathbf{W}$ & Total \\
\hline \multicolumn{11}{|c|}{ Late Lafourche Delta region-Continued } \\
\hline \multirow[t]{2}{*}{47} & 2008 & 0.14 & 3.54 & 15.70 & 135.46 & 71.66 & 0.00 & 0.00 & $2,147.31$ & $2,373.81$ \\
\hline & 2016 & 0.00 & 27.57 & 36.04 & 174.23 & 15.02 & 0.00 & 0.00 & $2,120.95$ & $2,373.81$ \\
\hline \multirow[t]{2}{*}{ RT } & 2008 & 31.51 & 165.26 & 57.58 & 124.56 & 113.00 & 0.59 & 1.07 & $7,880.49$ & $32,786.48$ \\
\hline & 2016 & 1.08 & 79.90 & 18.70 & 258.37 & 29.95 & 0.38 & 0.95 & $7,984.76$ & $32,786.54$ \\
\hline \multicolumn{11}{|c|}{ Modern Delta region } \\
\hline \multirow[t]{2}{*}{48} & 2008 & 14.67 & 79.50 & 142.29 & 984.09 & 541.83 & 0.11 & 2.49 & $6,320.61$ & $8,085.59$ \\
\hline & 2016 & 6.68 & 249.82 & 135.75 & 848.15 & 27.91 & 0.00 & 2.20 & $6,815.09$ & $8,085.60$ \\
\hline \multirow[t]{2}{*}{49} & 2008 & 1.37 & 19.92 & 32.36 & 490.62 & 176.58 & 1.15 & 0.69 & $9,102.42$ & $9,825.11$ \\
\hline & 2016 & 84.83 & 164.76 & 238.67 & 514.81 & 56.60 & 0.88 & 0.68 & $8,763.89$ & $9,825.12$ \\
\hline \multirow[t]{2}{*}{ RT } & 2008 & 16.04 & 99.42 & 174.65 & $1,474.71$ & 718.41 & 1.26 & 3.18 & $15,423.03$ & $17,910.70$ \\
\hline & 2016 & 91.51 & 414.58 & 374.42 & $1,362.96$ & 84.51 & 0.88 & 2.88 & $15,578.98$ & $17,910.72$ \\
\hline \multicolumn{11}{|c|}{ Chandeleur Islands region } \\
\hline \multirow[t]{2}{*}{59} & 2008 & 0.04 & 1.65 & 4.17 & 2.84 & 53.13 & 0.14 & 0.14 & $5,126.06$ & $5,188.17$ \\
\hline & 2016 & 0.00 & 8.33 & 24.83 & 10.23 & 32.31 & 0.08 & 0.29 & $5,112.08$ & $5,188.15$ \\
\hline \multirow[t]{2}{*}{60} & 2008 & 0.00 & 0.00 & 0.00 & 0.00 & 5.14 & 0.00 & 0.02 & $11,592.51$ & $11,597.67$ \\
\hline & 2016 & 0.00 & 3.13 & 32.92 & 1.89 & 77.31 & 0.00 & 0.01 & $11,482.41$ & $11,597.67$ \\
\hline \multirow[t]{2}{*}{61} & 2008 & 4.01 & 30.92 & 139.51 & 203.72 & 507.23 & 0.00 & 0.03 & $25,460.48$ & $26,345.90$ \\
\hline & 2016 & 2.36 & 75.30 & 306.75 & 369.42 & 333.71 & 0.00 & 0.03 & $25,258.33$ & $26,345.90$ \\
\hline \multirow[t]{2}{*}{ RT } & 2008 & 4.05 & 32.57 & 143.68 & 206.56 & 565.50 & 0.14 & 0.19 & $42,179.05$ & $43,131.74$ \\
\hline & 2016 & 2.36 & 86.76 & 364.50 & 381.54 & 443.33 & 0.08 & 0.33 & $41,852.82$ & $43,131.72$ \\
\hline \multicolumn{11}{|c|}{ BICM region-wide (fig. 1) } \\
\hline-- & 2008 & 420.90 & $5,536.79$ & $1,945.20$ & $55,845.54$ & $4,391.49$ & 31.47 & $1,265.05$ & $136,030.13$ & $205,466.57$ \\
\hline-- & $2015-16$ & 425.51 & $6,314.35$ & $1,625.87$ & $56,631.20$ & $1,193.46$ & 27.68 & $1,331.98$ & $137,916.64$ & $205,466.69$ \\
\hline
\end{tabular}


Table 1-3. Areal coverage (hectares) for land/water change between 2008 and 2015-16, by Louisiana Barrier Island Comprehensive Monitoring (BICM) Program reach. See figure 1 for reach location and name.

[LG, land gain; LL, land loss; LU, land unchanged; WU, water unchanged; RT, region total; --, not applicable]

\begin{tabular}{|c|c|c|c|c|c|}
\hline Reach & LG & LL & LU & WU & Total \\
\hline \multicolumn{6}{|c|}{ West Chenier Plain region } \\
\hline 1 & 309.58 & 104.49 & $5,173.60$ & $1,322.81$ & $6,910.48$ \\
\hline 2 & 145.82 & 41.68 & $3,378.58$ & $1,102.64$ & $4,668.72$ \\
\hline 3 & 237.10 & 13.82 & $1,469.28$ & $1,807.95$ & $3,528.15$ \\
\hline 4 & 192.32 & 57.57 & $5,426.48$ & $1,415.91$ & $7,092.28$ \\
\hline 5 & 57.83 & 36.16 & $1,839.70$ & $1,477.18$ & $3,410.87$ \\
\hline RT & 942.65 & 253.72 & $17,287.64$ & $7,126.49$ & $25,610.50$ \\
\hline \multicolumn{6}{|c|}{ East Chenier Plain region } \\
\hline 6 & 271.54 & 563.29 & $11,559.98$ & $10,037.18$ & $22,431.99$ \\
\hline 7 & 65.35 & 42.19 & $3,246.56$ & $1,615.42$ & $4,969.52$ \\
\hline 8 & 147.36 & 57.26 & $3,761.29$ & $1,185.64$ & $5,151.55$ \\
\hline 9 & 95.10 & 23.80 & $2,487.56$ & 996.25 & $3,602.71$ \\
\hline 10 & 23.85 & 31.49 & $3,049.29$ & $1,168.21$ & $4,272.84$ \\
\hline RT & 603.20 & 718.03 & $24,104.68$ & $15,002.70$ & $40,428.61$ \\
\hline \multicolumn{6}{|c|}{ Acadiana Bays region } \\
\hline 11 & 53.24 & 209.53 & $5,975.01$ & $3,099.47$ & $9,337.25$ \\
\hline \multicolumn{6}{|c|}{ Early Lafourche Delta region } \\
\hline 34 & 94.49 & 102.42 & $3,663.96$ & $3,098.06$ & $6,958.93$ \\
\hline 35 & 170.93 & 385.57 & $4,400.82$ & $8,070.34$ & $13,027.66$ \\
\hline 36 & 25.10 & 7.49 & 17.33 & $2,675.38$ & $2,725.30$ \\
\hline 37 & 161.23 & 74.49 & 351.60 & $4,272.80$ & $4,860.12$ \\
\hline 38 & 17.55 & 51.74 & 177.62 & $3,238.19$ & $3,485.10$ \\
\hline 39 & 4.55 & 39.54 & 57.12 & $2,195.33$ & $2,296.54$ \\
\hline 40 & 0.86 & 2.54 & 0.29 & $2,903.94$ & $2,907.63$ \\
\hline RT & 474.71 & 663.79 & $8,668.74$ & $26,454.04$ & $36,261.28$ \\
\hline \multicolumn{6}{|c|}{ Late Lafourche Delta region } \\
\hline 41 & 57.07 & 77.81 & 302.77 & $7,936.43$ & $8,374.08$ \\
\hline 42 & 13.33 & 36.75 & 21.27 & $3,763.47$ & $3,834.82$ \\
\hline 43 & 167.62 & 23.66 & 212.52 & $2,008.72$ & $2,412.52$ \\
\hline 44 & 220.97 & 352.56 & $2,497.43$ & $5,456.66$ & $8,527.62$ \\
\hline 45 & 130.83 & 50.40 & $1,082.47$ & $3,854.70$ & $5,118.40$ \\
\hline
\end{tabular}


Table 1-3. Areal coverage (hectares) for land/water change between 2008 and 2015-16, by Louisiana Barrier Island Comprehensive Monitoring (BICM) Program reach. See figure 1 for reach location and name.-Continued

[LG, land gain; LL, land loss; LU, land unchanged; WU, water unchanged; RT, region total; --, not applicable]

\begin{tabular}{|c|c|c|c|c|c|}
\hline Reach & LG & LL & LU & WU & Total \\
\hline \multicolumn{6}{|c|}{ Late Lafourche Delta region-Continued } \\
\hline 46 & 19.58 & 20.01 & 174.84 & $1,930.81$ & $2,145.24$ \\
\hline 47 & 107.89 & 23.47 & 131.37 & $2,111.08$ & $2,373.81$ \\
\hline RT & 717.29 & 584.66 & $4,422.67$ & $27,061.87$ & $32,786.49$ \\
\hline \multicolumn{6}{|c|}{ Modern Delta region } \\
\hline 48 & 260.36 & 230.21 & 992.95 & $6,602.08$ & $8,085.60$ \\
\hline 49 & 572.5 & 113.47 & 432.65 & $8,706.49$ & $9,825.11$ \\
\hline RT & 832.86 & 343.68 & $1,425.60$ & $15,308.57$ & $17,910.71$ \\
\hline \multicolumn{6}{|c|}{ Chandeleur Islands region } \\
\hline 59 & 35.82 & 1.33 & 7.63 & $5,143.37$ & $5,188.15$ \\
\hline 60 & 37.65 & 0.02 & 0.01 & $11,560.00$ & $11,597.68$ \\
\hline 61 & 477.63 & 101.45 & 276.74 & $25,490.08$ & $26,345.90$ \\
\hline RT & 551.10 & 102.8 & 284.38 & $42,193.45$ & $43,131.73$ \\
\hline \multicolumn{6}{|c|}{ BICM region-wide (fig. 1) } \\
\hline-- & $4,175.05$ & $2,876.21$ & $62,168.72$ & $136,246.59$ & $205,466.57$ \\
\hline
\end{tabular}


Table 1-4. Areal coverage (hectares) for inundation zone-based habitat change classes for change between 2008 and 20-2016, by Louisiana Barrier Island Comprehensive Monitoring (BICM) Program reach. See figure 1 for reach location and name.

[DSPG, developed/shoreline protection gain; DSPL, developed/shoreline protection loss; IUV-IV, intertidal-unvegetated to intertidal-vegetated; IUV-S, intertidal-unvegetated to supratidal/upland; IUV-W, intertidal-unvegetated to water; IV-IUV, intertidal-vegetated to intertidal-unvegetated; IV-S, intertidal-vegetated to supratidal/upland; IV-W, intertidal-vegetated to water; S-IUV; supratidal/upland to intertidalunvegetated; S-IV, supratidal/upland to intertidal-vegetated; S-W, supratidal/upland to water; U, unchanged; W-IUV, water to intertidal-unvegetated; W-IV, water to intertidal-vegetated; W-S, water to supratidal/upland; RT, region total; --, not applicable]

\begin{tabular}{|c|c|c|c|c|c|c|c|c|c|c|c|c|c|c|c|c|}
\hline Reach & DSPG & DSPL & IUV-IV & IUV-S & IUV-W & IV-IUV & IV-S & IV-W & S-IUV & S-IV & S-W & $\mathbf{U}$ & W-IUV & W-IV & W-S & Total \\
\hline \multicolumn{17}{|c|}{ West Chenier Plain region } \\
\hline 1 & 9.67 & 8.18 & 42.65 & 23.37 & 58.85 & 51.68 & 55.43 & 19.95 & 11.09 & 108.27 & 20.94 & $6,242.85$ & 14.89 & 226.01 & 16.64 & $6,910.47$ \\
\hline 2 & 10.85 & 6.77 & 8.81 & 13.78 & 58.11 & 8.17 & 31.86 & 14.36 & 8.05 & 19.98 & 9.60 & $4,352.85$ & 2.49 & 117.76 & 5.27 & $4,668.71$ \\
\hline 3 & 12.46 & 0.67 & 0.41 & 19.08 & 3.79 & 0.42 & 7.31 & 10.48 & 1.11 & 6.44 & 1.65 & $3,235.85$ & 11.34 & 191.78 & 25.37 & $3,528.16$ \\
\hline 4 & 50.17 & 15.12 & 39.07 & 58.05 & 42.92 & 7.68 & 156.10 & 32.15 & 6.21 & 160.67 & 11.24 & $6,408.80$ & 9.41 & 77.69 & 16.99 & $7,092.27$ \\
\hline 5 & 0.66 & 0.22 & 28.05 & 2.39 & 125.16 & 1.72 & 22.87 & 6.26 & 7.89 & 9.65 & 20.12 & $3,144.65$ & 14.04 & 26.82 & 0.39 & $3,410.89$ \\
\hline RT & 83.81 & 30.96 & 118.99 & 116.67 & 288.83 & 69.67 & 273.57 & 83.20 & 34.35 & 305.01 & 63.55 & $23,385.00$ & 52.17 & 640.06 & 64.66 & $25,610.50$ \\
\hline \multicolumn{17}{|c|}{ East Chenier Plain region } \\
\hline 6 & 0.81 & 1.19 & 14.15 & 3.03 & 207.42 & 36.11 & 246.71 & 220.15 & 9.92 & 40.97 & 296.99 & $21,032.13$ & 68.34 & 250.73 & 3.32 & $22,431.97$ \\
\hline 7 & 0.01 & 0.01 & 0.62 & 0.58 & 26.48 & 3.08 & 56.18 & 15.04 & 4.08 & 80.05 & 19.98 & $4,699.25$ & 0.01 & 63.56 & 0.59 & $4,969.52$ \\
\hline 8 & 1.18 & 2.64 & 1.90 & 0.15 & 1.74 & 0.53 & 88.28 & 7.23 & 1.07 & 69.47 & 48.36 & $4,783.81$ & 0.15 & 144.03 & 1.02 & $5,151.56$ \\
\hline 9 & 0.36 & 0.36 & 0.06 & 0.31 & 11.49 & 0.33 & 97.88 & 2.75 & 5.62 & 29.76 & 15.09 & $3,343.38$ & 0.67 & 92.21 & 2.42 & $3,602.69$ \\
\hline 10 & 0.45 & 0.01 & 0.41 & 1.34 & 4.49 & 1.42 & 26.32 & 13.97 & 6.15 & 18.79 & 9.94 & $4,166.21$ & 1.69 & 19.85 & 1.81 & $4,272.85$ \\
\hline RT & 2.81 & 4.21 & 17.14 & 5.41 & 251.62 & 41.47 & 515.37 & 259.14 & 26.84 & 239.04 & 390.36 & $38,024.78$ & 70.86 & 570.38 & 9.16 & $40,428.59$ \\
\hline \multicolumn{17}{|c|}{ Acadiana Bays region } \\
\hline 11 & 0.04 & 0.00 & 15.78 & 0.84 & 69.34 & 2.20 & 142.61 & 166.94 & 8.99 & 41.21 & 31.39 & $8,820.54$ & 0.74 & 36.27 & 0.35 & $9,337.24$ \\
\hline \multicolumn{17}{|c|}{ Early Lafourche Delta region } \\
\hline 34 & 0.50 & 0.85 & 45.07 & 3.80 & 214.66 & 3.08 & 44.89 & 46.56 & 5.17 & 19.00 & 45.97 & $6,486.67$ & 0.40 & 40.11 & 2.19 & $6,958.92$ \\
\hline 35 & 0.11 & 0.47 & 145.83 & 0.79 & 563.51 & 5.24 & 18.46 & 345.56 & 2.07 & 4.50 & 30.22 & $11,889.18$ & 1.02 & 19.76 & 0.93 & $13,027.65$ \\
\hline 36 & 0.02 & 0.42 & 0.67 & 6.66 & 35.51 & 0.53 & 0.67 & 1.59 & 0.65 & 1.50 & 4.17 & $2,638.96$ & 16.74 & 3.49 & 13.72 & $2,725.30$ \\
\hline 37 & 0.27 & 0.02 & 31.81 & 7.50 & 79.16 & 1.58 & 3.83 & 28.87 & 2.27 & 14.16 & 40.67 & $4,520.72$ & 10.13 & 107.09 & 12.03 & $4,860.11$ \\
\hline 38 & 0.01 & 0.00 & 6.04 & 3.28 & 31.47 & 0.57 & 1.94 & 12.06 & 5.08 & 1.49 & 33.35 & $3,376.25$ & 6.38 & 0.76 & 6.41 & $3,485.09$ \\
\hline 39 & 0.08 & 0.25 & 1.26 & 1.46 & 18.44 & 0.24 & 1.02 & 2.07 & 1.42 & 0.23 & 35.28 & $2,232.09$ & 1.32 & 0.63 & 0.75 & $2,296.54$ \\
\hline 40 & 0.30 & 0.11 & 0.00 & 0.04 & 2.59 & 0.02 & 0.00 & 0.37 & 0.18 & 0.00 & 1.84 & $2,899.94$ & 1.72 & 0.00 & 0.52 & $2,907.63$ \\
\hline RT & 1.29 & 2.12 & 230.68 & 23.53 & 945.34 & 11.26 & 70.81 & 437.08 & 16.84 & 40.88 & 191.50 & $34,043.81$ & 37.71 & 171.84 & 36.55 & $36,261.24$ \\
\hline
\end{tabular}


Table 1-4. Areal coverage (hectares) for inundation zone-based habitat change classes for change between 2008 and 20-2016, by Louisiana Barrier Island Comprehensive Monitoring (BICM) Program reach. See figure 1 for reach location and name.-Continued

[DSPG, developed/shoreline protection gain; DSPL, developed/shoreline protection loss; IUV-IV, intertidal-unvegetated to intertidal-vegetated; IUV-S, intertidal-unvegetated to supratidal/upland; IUV-W, intertidal-unvegetated to water; IV-IUV, intertidal-vegetated to intertidal-unvegetated; IV-S, intertidal-vegetated to supratidal/upland; IV-W, intertidal-vegetated to water; S-IUV; supratidal/upland to intertidalunvegetated; S-IV, supratidal/upland to intertidal-vegetated; S-W, supratidal/upland to water; U, unchanged; W-IUV, water to intertidal-unvegetated; W-IV, water to intertidal-vegetated; W-S, water to supratidal/upland; RT, region total; --, not applicable]

\begin{tabular}{|c|c|c|c|c|c|c|c|c|c|c|c|c|c|c|c|c|}
\hline Reach & DSPG & DSPL & IUV-IV & IUV-S & IUV-W & IV-IUV & IV-S & IV-W & S-IUV & S-IV & S-W & $\mathbf{U}$ & W-IUV & W-IV & W-S & Total \\
\hline \multicolumn{17}{|c|}{ Late Lafourche Delta region } \\
\hline 41 & 0.41 & 0.71 & 10.28 & 20.40 & 71.83 & 0.65 & 1.83 & 26.22 & 4.74 & 26.74 & 44.71 & $8,125.53$ & 15.76 & 6.29 & 17.97 & $8,374.07$ \\
\hline 42 & 0.68 & 1.99 & 1.36 & 2.17 & 40.45 & 0.81 & 0.94 & 11.85 & 0.99 & 1.02 & 20.77 & $3,734.94$ & 8.17 & 3.64 & 5.04 & $3,834.82$ \\
\hline 43 & 0.28 & 0.59 & 31.47 & 21.91 & 26.84 & 2.32 & 10.26 & 7.25 & 3.63 & 7.79 & 9.49 & $2,162.37$ & 17.62 & 22.04 & 88.68 & $2,412.54$ \\
\hline 44 & 4.91 & 7.61 & 59.74 & 69.49 & 143.96 & 8.53 & 60.88 & 298.70 & 14.34 & 28.72 & 25.29 & $7,712.00$ & 21.32 & 31.23 & 40.90 & $8,527.62$ \\
\hline 45 & 28.59 & 10.89 & 35.40 & 35.31 & 54.13 & 0.36 & 9.51 & 39.99 & 1.50 & 19.99 & 5.04 & $4,822.19$ & 8.47 & 27.17 & 19.85 & $5,118.39$ \\
\hline 46 & 0.30 & 1.53 & 3.80 & 8.12 & 11.78 & 1.12 & 3.10 & 8.03 & 2.41 & 7.90 & 7.16 & $2,079.52$ & 3.82 & 1.55 & 5.09 & $2,145.23$ \\
\hline 47 & 0.00 & 0.00 & 19.76 & 16.72 & 29.30 & 0.78 & 11.13 & 18.08 & 1.28 & 5.51 & 2.76 & $2,189.22$ & 9.77 & 44.70 & 24.80 & $2,373.81$ \\
\hline RT & 35.17 & 23.32 & 161.81 & 174.12 & 378.29 & 14.57 & 97.65 & 410.12 & 28.89 & 97.67 & 115.22 & $30,825.77$ & 84.93 & 136.62 & 202.33 & $32,786.48$ \\
\hline \multicolumn{17}{|c|}{ Modern Delta region } \\
\hline 48 & 0.52 & 0.81 & 53.62 & 59.23 & 398.64 & 5.47 & 60.58 & 194.80 & 5.08 & 35.31 & 24.20 & $7,091.97$ & 8.23 & 47.18 & 99.96 & $8,085.60$ \\
\hline 49 & 0.04 & 0.24 & 37.28 & 47.55 & 77.39 & 1.97 & 37.80 & 104.06 & 0.84 & 4.50 & 6.40 & $8,973.37$ & 46.06 & 130.45 & 357.19 & $9,825.14$ \\
\hline RT & 0.56 & 1.05 & 90.90 & 106.78 & 476.03 & 7.44 & 98.38 & 298.86 & 5.92 & 39.81 & 30.60 & $16,065.34$ & 54.29 & 177.63 & 457.15 & $17,910.74$ \\
\hline \multicolumn{17}{|c|}{ Chandeleur Islands region } \\
\hline 59 & 0.15 & 0.05 & 2.62 & 13.79 & 27.83 & 0.10 & 0.67 & 0.17 & 0.33 & 1.98 & 0.69 & $5,097.39$ & 23.14 & 3.62 & 15.65 & $5,188.18$ \\
\hline 60 & 0.01 & 0.02 & 0.09 & 1.32 & 2.44 & 0.00 & 0.00 & 0.00 & 0.00 & 0.00 & 0.00 & $11,481.65$ & 75.91 & 1.77 & 34.47 & $11,597.68$ \\
\hline 61 & 0.01 & 0.01 & 77.11 & 88.93 & 257.34 & 2.98 & 17.46 & 40.55 & 17.24 & 23.25 & 40.66 & $25,236.81$ & 231.97 & 128.38 & 183.2 & $26,345.90$ \\
\hline RT & 0.17 & 0.08 & 79.82 & 104.04 & 287.61 & 3.08 & 18.13 & 40.72 & 17.57 & 25.23 & 41.35 & $41,815.85$ & 331.02 & 133.77 & 233.32 & $43,131.76$ \\
\hline \multicolumn{17}{|c|}{ BICM region-wide (fig. 1) } \\
\hline-- & 123.85 & 61.74 & 715.12 & 531.39 & $2,697.06$ & 149.69 & $1,216.52$ & $1,696.06$ & 139.40 & 788.85 & 863.97 & $192,981.09$ & 631.72 & $1,866.57$ & $1,003.52$ & $205,466.55$ \\
\hline
\end{tabular}






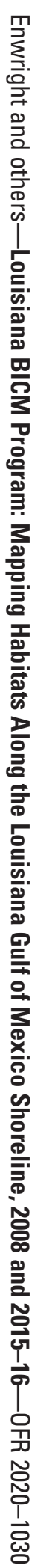

